\title{
Evolution and Performance of Exchange Rate Regimes
}

Kenneth S. Rogoff, Aasim M. Husain, Ashoka Mody, Robin Brooks, and Nienke Oomes

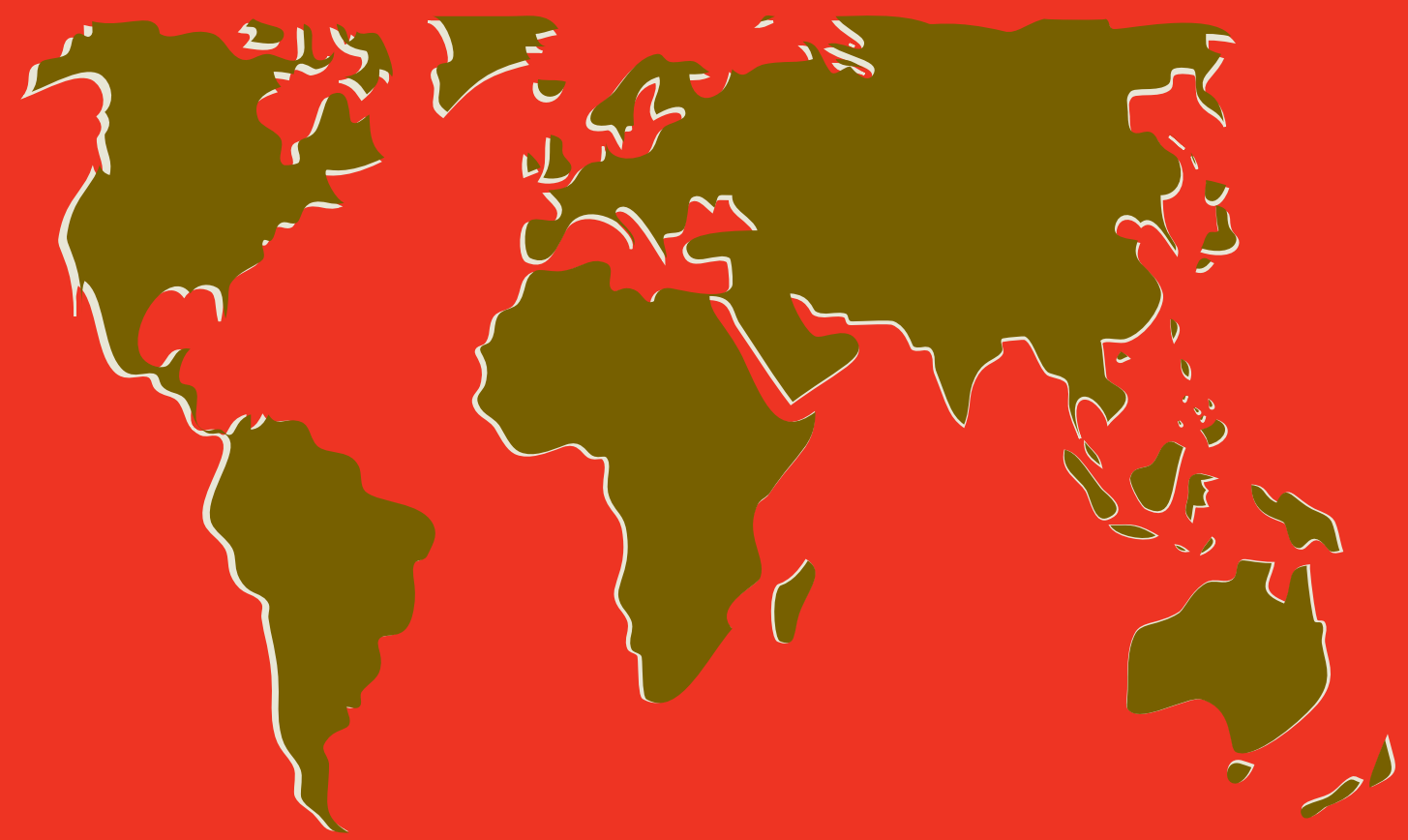




\section{Evolution and Performance of Exchange Rate Regimes}

Kenneth S. Rogoff, Aasim M. Husain, Ashoka Mody,

Robin Brooks, and Nienke Oomes 


\section{(C) 2004 International Monetary Fund}

Production: IMF Multimedia Services Division

Figures: Theodore F. Peters, Jr.

Typesetting: Alicia Etchebarne-Bourdin

\section{Cataloging-in-Publication Data}

Evolution and performance of exchange rate regimes/Kenneth $\mathrm{S}$. Rogoff . . . [et al.]—Washington, D.C.: International Monetary Fund [2004].

p. cm.-(Occasional paper; 229)

Includes bibliographical references

ISBN 1-58906-327-9

1. Foreign exchange rates. 2. Foreign exchange rates-Developing countries. 3. Inflation (Finance). 4. Business cycles. I. Rogoff, Kenneth S. II. Occasional paper (International Monetary Fund); 229.

HG3811.E96 2004

Price: US $\$ 25.00$

(US\$22.00 to full-time faculty members and students at universities and colleges)

Please send orders to:

International Monetary Fund, Publication Services 700 19th Street, N.W., Washington, D.C. 20431, U.S.A.

Tel.: (202) 623-7430 Telefax: (202) 623-7201

E-mail: publications@imf.org

Internet: http://www.imf.org

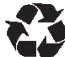

recycled paper 


\section{Contents}

Preface vii

I. Overview I

II. The Evolution of Exchange Rate Regimes: A Fresh Look 4

New Regime Classifications 5

Divergence Between Stated and Actual Policies 6

Regime Transitions 12

Implications for Assessing Regime Performance 14

Appendix I. The Natural Classification 14

Appendix II. Determinants of Exchange Rate Regime Choice 16

III. Regime Performance: Inflation and Business Cycles 21

Summary of Empirical Analysis of Exchange Rate Regimes 22

Analytical Considerations $\quad 23$

Macroeconomic Performance and Crisis Probabilities: Summary
Statistics

Regime Performance and Levels of Development 28

Achieving Credibility in Developing and Emerging Economies 35

Appendix. Data and Regression Results for Economic

Performance Analysis 37

IV. Summary 49

$\begin{array}{ll}\text { References } & 50\end{array}$

Box

2.1. Anchor Currency Choice 10

\section{Tables}

2.1. Annual Transition Probabilities 13

3.1. Economic Performance Across Exchange Rate Regimes 24

3.2. Average Annual Inflation and Real Per Capita GDP Growth:

Comparison of Dual (or Multiple) and Unified Exchange Rate Systems, 1970-99

3.3. Average Annual Inflation Rates Across Exchange Rate Regimes, 1970-99

3.4. Average Annual Real Per Capita GDP Growth Across Exchange Rate Regimes, 1970-99

3.5. Average Annual Growth Volatility Across Exchange Rate Regimes, 1970-99

3.6. Real Exchange Rate Volatility Across Exchange Rate Regimes, 1970-2002 
3.7. Probability of Crises During Specific Regimes Using the Natural Exchange Rate Regime Classification

\section{Appendix Tables}

A2.1. Main Features of Various De Facto Classifications 15

A2.2. Natural Classification Categories

A2.3. Studies on Determinants of Exchange Rate Regimes (Likelihood to Float)

A3.1. Variable Description

A3.2. List of Countries

A3.3 Comparing IMF De Jure and Natural Classifications 41

A3.4. Inflation Performance Across Country Groups 42

A3.5. Growth Performance Across Country Groups 43

A3.6. Volatility of Real GDP Growth Performance Across Country Groups

A3.7. Emerging Markets in the 1990s

A3.8. Inflation Performance in Developing Countries: Announcement and Duration Effects

A3.9. Robustness Tests

\section{Figures}

2.1. Natural Classification Regimes by De Jure Category, 1973-99 7

2.2 Countries with Dual/Parallel Foreign Exchange Markets

2.3 Natural Classification Regime Distribution

2.4 De Jure Regime Distribution

2.5. Natural Classification Regime Distribution by Country Group

2.6. IMF De Facto Regime Distribution

2.7. Levy-Yeyati-Sturzenegger Regime Distribution

2.8. Natural Classification Regime Transitions

3.1. Inflation Performance Across Regimes: Confidence Effect

3.2. Inflation Performance Across Regimes: Confidence and Discipline Effects

3.3. Inflation Performance in Advanced Countries, Emerging Markets, and Developing Countries: Confidence Effect

3.4. Inflation Performance in Advanced Countries, Emerging Markets, and Developing Countries: Confidence and Discipline Effects

3.5. Growth Performance Across Regimes

3.6. Growth Performance in Advanced Countries, Emerging Markets, and Developing Countries

3.7. Volatility of Real GDP Growth Performance Across Regimes 33

3.8. Volatility of Real GDP Growth Performance in Advanced Countries, Emerging Markets, and Developing Countries $\quad 34$

3.9. Volatility of Real GDP Growth and Contamination Across Regimes: Evidence from Emerging Markets

3.10. Volatility of Real GDP Growth Across Regimes: Emerging Markets for the 1990s Only

3.11. The Inflation Benefit Associated with Announcement in Developing Countries

3.12. The Inflation Benefit Associated with Consistent Macroeconomic Policies in Developing Countries 
The following symbols have been used throughout this paper:

... to indicate that data are not available;

- to indicate that the figure is zero or less than half the final digit shown, or that the item does not exist;

- between years or months (e.g., 2003-04 or January-June) to indicate the years or months covered, including the beginning and ending years or months;

/ between years (e.g., 2003/04) to indicate a fiscal (financial) year.

"n.a." means not applicable.

"Billion" means a thousand million.

Minor discrepancies between constituent figures and totals are due to rounding.

The term "country," as used in this paper, does not in all cases refer to a territorial entity that is a state as understood by international law and practice; the term also covers some territorial entities that are not states, but for which statistical data are maintained and provided internationally on a separate and independent basis. 



\section{Preface}

The issue of the appropriate exchange rate regime for a country has been perennially lively, with a new set of considerations coming to the fore in the 1990s. The role played by international capital flows and domestic financial systems in determining the performance of exchange rate regimes has gained prominence in the policy debate over the appropriate exchange rate arrangement.

Using recent advances in the classification of exchange rate regimes to draw new lessons about the performance of alternative regimes, this paper's key message is that, as economies and their institutions mature, the value of exchange rate flexibility increases. In reaching this overarching conclusion, the paper takes an empirical perspective to form a judgment of actual experience. The study takes as a given that multiple currencies will continue to exist in the foreseeable future. Hence, the policy analysis is intended for countries that choose to retain their own currencies.

The study was prepared by a staff team under the direction of Kenneth Rogoff, when he was Economic Counsellor and Director of the IMF's Research Department. The team was led by Aasim Husain and Ashoka Mody, and included Robin Brooks and Nienke Oomes. The authors would like to acknowledge contributions from Andrew Berg, who worked on the subsection "Learning to Float" in Section III; Paolo Mauro and Grace Juhn, who provided the subsection "Empirical Findings on Factors Affecting Regime Choice" in Appendix II; and Antonio Spilimbergo, who did the estimations for the subsection "Regimes and Crisis Probabilities" in Section III. The paper also benefited from useful comments and suggestions from Tamim Bayoumi, Michael Bordo, Agustín Carstens, Barry Eichengreen, İnci Ötker-Robe, Jacques Polak, Carmen Reinhart, David J. Robinson, Miguel Savastano, Federico Sturzenegger, Lars Svensson, and numerous other colleagues throughout the Fund. Young Kim and Eisuke Okada provided valuable research assistance. Atish Ghosh generously shared his data set. Sheila Kinsella managed the Research Department end in the preparation of this paper. Gail Berre of the External Relations Department edited the paper and coordinated production of the publication.

An earlier draft of the paper was presented at an informal seminar of the IMF's Executive Board, and the current version has benefited from the comments made on that occasion. The views expressed are those of the authors, however, and do not necessarily reflect those of national authorities or IMF Executive Directors. 



\section{Overview}

$\mathbf{T}$ his study assesses the historical durability and performance of alternative exchange rate regimes, with special focus on developing and emerging market countries. It suggests that the popular bipolar view of exchange rates is neither an accurate description of the past nor a likely scenario for the next decade. While the study confirms that emerging market countries need to consider adopting more flexible exchange rate regimes as they develop economically and institutionally, it also finds that fixed or relatively rigid exchange rate regimes have not performed badly for poorer countries. For countries that have relatively limited financial market development and relatively closed capital markets, fixed exchange rate regimes appear to offer some measure of credibility without compromising growth objectives-with the important proviso that monetary policy must be consistent in avoiding a large and volatile parallel market premium. As countries develop economically and institutionally, there are considerable benefits to adopting a more flexible exchange rate system - although, of course, the following analysis provides only a general guide and should not be interpreted as a one-size-fits-all prescription. For developed countries that are not in a currency union (or headed toward one), relatively flexible exchange rate regimes offer higher growth without any cost in anti-inflation credibility-provided they are anchored by some other means, such as an independent central bank with a clear antiinflation mandate. One perhaps surprising finding of the quantitative analysis is the remarkable durability of exchange rate regimes outside of emerging market countries, with only 7 percent of all countries changing regimes in an average year over the 1940-2001 period.

Debates on the appropriate exchange rate regime for a country are perennially lively. In the 1990s, a new set of considerations came to the fore, particularly the role played by international capital flows and domestic financial systems in determining the performance of exchange rate regimes. Just when pegged regimes were gaining respectability as providing nominal anchors, several pegs (and crawling pegs) faced speculative pressures from investors who were skeptical of the regimes' sustainability. Many such episodes were associated with costly financial crises, especially in emerging markets. One influential view predicted that exchange rate regimes would move in a bipolar manner to the extremes of hard pegs, which would be relatively immune to speculative pressures or free floats (Eichengreen, 1994; and Fischer, 2001). An increasing number of countries did announce their intent to allow greater exchange rate flexibility. Among developing and emerging market economies, however, the de jure announcement to float did not typically translate into de facto fully floating exchange rates. Countries, it appeared, had a fear of floating (Calvo and Reinhart, 2002).

These observed trends and policy ambivalence reflected a variety of opposing considerations in the adoption and performance of exchange rate regimes. In their discussions of papers on exchange rate regimes in September and November 1999, IMF Executive Directors concluded that there were no simple prescriptions for the choice of a country's exchange rate regime. ${ }^{1}$ Instead, they emphasized the importance of macroeconomic fundamentals and the consistency of the exchange rate regime with underlying macroeconomic policies. Several also thought that a range of alternatives between the polar extremes of rigidity and flexibility were viable. More recently, however, the IMF has been urged-from outside as well as within-to take a more prescriptive role in its surveillance of members' exchange rate policies and regime choice, underscoring the importance of an improved understanding of the performance of alternate regimes (Calomiris, 1998; International Financial Institution Advisory Commission, 2000; Mussa, 2002; and IMF, Independent Evaluation Office, 2003c).

While recognizing the central importance of macroeconomic fundamentals, this study uses recent advances in the classification of exchange rate regimes to draw new lessons from the performance

\footnotetext{
${ }^{1}$ See the summings up of IMF Board discussions in Mussa and others (2000).
} 
of alternative regimes. The findings indicate that, as economies and their institutions mature, the value of exchange rate flexibility increases. This conclusion reflects distinctions among advanced, emerging, and other developing economies. Emerging markets have stronger links to international capital markets than do other developing economies. Unlike advanced economies, however, emerging markets face a variety of institutional weaknesses that manifest themselves in higher inflation, problems of debt sustainability, fragile banking systems, and other sources of macroeconomic volatility, all of which potentially undermine the credibility of policymakers. Thus, while the non-emerging market developing countries (hereinafter referred to as developing economies) may gain credibility through pegging their exchange rates, emerging market economies find it harder to do so and could benefit from investing in learning to float. More advanced economies, with their stronger institutions, are best positioned to enjoy the benefits of flexibility without the risk of losing policy credibility.

To be clear, this study takes as a given the current conjuncture of a multiplicity of currencies. As such, the conclusions apply to those countries that have their own currencies. It is possible, however, that the current context may evolve, and a sufficiently large number of countries may, in the next decade and beyond, elect to join currency unions, leading to fewer currencies in circulation. This would change the behavior of governments and international business, and, hence, change the economic performance of alternative regimes in ways that the following does not attempt to predict. ${ }^{2}$

Because analytical arguments on the economic influence of exchange rate regimes often lead to opposing conclusions, this study bases its perspective on actual experience. Empirical observations are used to form judgments on how offsetting factors play out in different country groups. The simple groupings do not allow for complexities at the level of individual countries, however, by reflecting, for example, their economic size and internal heterogeneity.

Empirical analysis of exchange rate regime performance depends, of course, on the classification of regimes. The conclusions of this study rely on the distinction between de jure and de facto regimes. Owing to the importance of this distinction, attempts have been made in recent years to characterize de facto regimes using information on the actual behav-

${ }^{2}$ IMF (2003a) concludes, however, that while Group of Three (G-3) exchange rate volatility has real effects, especially on some countries with high debt ratios and mismatches in trade and financial flows, the overall effects are small. ior of exchange rates that is supplemented by data on the movement of foreign exchange reserves and interest rates, as well as judgments on the true intent of policymakers. Based on such an effort, the IMF now compiles the de facto exchange rate regimes of its member countries, dating back to 1990 (IMF, 1999 and 2003b). The de facto regime classification principally used in this study is the "Natural" classification proposed by Reinhart and Rogoff (2004) which is available from the 1940s for virtually all IMF member countries. Among its distinguishing features is the use of parallel market exchange rates to determine the actual operation of an exchange rate regime and the identification of a separate category of freely falling regimes that are characterized by high inflation, and thus, implicitly, by weak macroeconomic management.

This study has two additional main sections. Section II first discusses several alternative exchange rate regime classification systems and reviews perspectives they offer. It describes trends in the distribution of regimes, noting the difference between de jure trends, which show a move to flexibility, and de facto trends, which show that intermediate exchange rate arrangements are still pervasive. The section also examines the transitions between regimes and finds that de facto regimes tend to be long-lived. The bulk of the de facto regime transitions in the past half century have occurred in the wake of exceptional events, such as the breakdown of the Bretton Woods system, the creation of the $\mathrm{Eu}-$ ropean Economic and Monetary Union, and the collapse of the Soviet Union. In the absence of such events, the present global distribution of regimes is not likely to change substantially. Over the longer term, however, political economy considerations may guide regime choice in some countries, possibly resulting in their election to form or join a currency union. Such transitions, of course, are beyond the scope of this analysis.

Section III studies the performance of exchange rate regimes in terms of inflation and business cycles. It finds that the advantages of exchange rate flexibility increase as a country becomes more integrated into global capital markets and develops a sound financial system. Free floats have, on average, registered faster growth than other regimes in advanced countries, without incurring higher inflation. Conversely, in developing countries with limited access to private external capital, pegs and other limited-flexibility arrangements have also been associated with lower inflation, without an apparent cost in terms of lower growth or higher growth volatility. In emerging market economies with higher exposure to international capital flows, however, the more rigid regimes have had a higher incidence of crises. The analysis also indicates that 
macroeconomic performance under all types of de facto regimes was weaker in countries with dual or multiple exchange rates that deviated substantially from official rates, suggesting important gains from exchange rate unification.

The analysis and results in this study are subject to a number of qualifications. First, empirical findings may reflect in part the influence of economic performance on the choice of regime, rather than the other way around. Second, an inherent difficulty arises in classifying regimes in a fully specified manner. A country's true exchange rate regime is, properly speaking, a super regime consisting of a sequence of regimes and not just the one that prevails at a particular point in time. Thus, the harmful effects of a regime may be observed only when it collapses, leading to a misattribution of the poor performance to the successor regime. Third, some of the conclusions depend on the choice of the Natural classification. To the extent possible, such conclusions are compared with results obtained using other classifications to assess the robustness of the conclusion or to explain why the differences arise. Fourth, the need for caution arises from the fact that, although a country's regime is conventionally classified as fixed, if its currency is fixed with respect to a single other currency, then performance is a function of multiple relationships with all partner currencies. The combining of multiple relationships into one has both descriptive and prescriptive consequences. For example, in classifying Argentina as a hard peg case, one loses sight of the fact that, in relation to the great majority of its trading partners, the peg to the dollar made it a floater. Finally, further analysis is needed to jointly classify exchange rate regimes and capital account openness. For all these reasons, while the conclusions and policy implications drawn in this study offer new cross-country perspectives on exchange rate regimes, the results should be interpreted with suitable caution, especially for individual cases. 


\section{The Evolution of Exchange Rate Regimes: A Fresh Look}

s there an observed tendency for exchange rate regimes to drift to the polar extremes of hard pegs and free floats, with a hollowing of the middle between the two? Have regime changes become significantly more frequent in the post-Bretton Woods era? And have certain regimes historically proven more difficult to sustain, particularly in countries more open to capital flows? Policy debates centered around these questions have forced a growing recognition that the exchange rate regime a country actually operates (its de facto regime) often differs meaningfully from its announced (or de jure) regime. This divergence affects potentially the analysis of historical trends in exchange rate regimes, their macroeconomic performance, and the answers to salient policy questions.

In recognition of the divergence between actual and operational regimes, a number of efforts have been undertaken to develop a classification of de facto rather than de jure regimes. The IMF now publishes regime classifications that take into account the actual functioning of regimes; these are available from 1990, and findings based on this classification are reported in IMF (2003b). The Natural classification, developed by Reinhart and Rogoff (2004), extends back to the 1940s, and overlaps significantly with the IMF de facto classification in the 1990s. The Natural classification also draws analytically useful distinctions that facilitate the interpretation of countries' economic behavior and performance.

This section describes the evolution of exchange rate regimes across the world using primarily the Natural classification, but provides also comparisons with other (including the de jure) classifications. Below are the main findings.

- Historically, the actual operation of exchange rate regimes seems to have differed from the announced framework about 50 percent of the time. Many countries have exhibited a fear of floating; as a result, the actual flexibility of their exchange rate was substantially less than announced.

- Intermediate regimes remain prevalent, especially among emerging markets and other devel- oping countries. The so-called "middle" along the flexibility dimension continues to constitute half of all regimes, as it has throughout the past three decades. Freely floating regimes remain rare. The moderate increase in the number of pegs in the 1990s was mainly in the euro area and the transition economies.

- The frequency of regime transitions today is similar to what it was 50 years ago. Since 1940, around 7 percent of all countries have changed their regime in a given year, with emerging markets tending to switch regimes more frequently than other countries. Apart from transitions related to major global or regional events in economies experiencing severe macroeconomic stress, changes in de facto regimes in the postBretton Woods period have been about as frequent as during the period of fixed parities.

This section also provides a brief discussion of the different approaches to exchange rate regime classification and documents the evolution of regimes across the world from 1940. It considers transitions across regimes, and concludes with some observations of how the choice of a classification system might affect the assessment of the performance of alternate regimes. Throughout the section, differences across economies that are at different stages of development and integration into global capital markets are highlighted by dividing countries into three groups-advanced, emerging market, and other developing economies. ${ }^{3}$

${ }^{3}$ Emerging market economies are those that are included in the Morgan Stanley Capital International (MSCI) index, and comprises Argentina, Brazil, Chile, China, Colombia, Czech Republic, Egypt, Hungary, India, Indonesia, Israel, Jordan, Korea, Malaysia, Mexico, Morocco, Pakistan, Peru, the Philippines, Poland, Russia, South Africa, Thailand, Turkey, and República Bolivarian de Venezuela. With the exception of Israel, advanced economies are those that are classified as upper-income economies by the World Bank. All other economies constitute the other developing countries group. Small variations in the composition of the emerging markets group do not alter the thrust of the findings reported below on the evolution of regimes and regime transitions. Recognizing the significant variation in financial integration across countries 


\section{New Regime Classifications}

Until the late 1990s, most empirical studies of exchange rate regimes relied on the de jure regime classification reported in the IMF's Annual Report on Exchange Arrangements and Exchange Restrictions (AREAER), which was then based on countries' official notifications to the IMF. The de jure classification distinguished between three broad categories-pegged regimes, regimes with limited flexibility (usually within a band or cooperative arrangement), and more flexible arrangements (those with managed or free floats) - which were then divided into 15 subcategories. 4

Although comprehensive in terms of country and historical coverage, the de jure classification system had a serious drawback: in practice, exchange rate regimes often differed from what they were officially announced to be. For example, some pegged regimes devalued frequently, while many floats typically moved within a tight band. Consequently, the de jure classification characterized inaccurately the distribution of operative currency regimes across the world and over time. Moreover, empirical analyses employing this classification to test theories of regime choice or to assess the relationship between regime choice and economic performance risked reaching incorrect conclusions and drawing misleading policy implications. ${ }^{5}$

Recognizing the merits of classifying regimes more realistically, a number of new de facto classification systems have been proposed. Ghosh and others (1997) classify regimes on a de facto basis using information on actual exchange rate movements. Subsequently, the evidence on macroeconomic performance under alternative de jure regimes was reexamined by Ghosh, Gulde, and Wolf (2003) by checking the robustness of these results against a hybrid de jure/de facto classification. ${ }^{6}$ Another classification system, devised by Levy-Yeyati and Sturzenegger (2002 and 2003), discards the de jure classification altogether and instead employs purely statistical techniques to exchange rate and reserves data to de-

and over time within the emerging markets group, this study also reports results for the 1990-2001 period where relevant.

${ }^{4}$ See Ghosh, Gulde, and Wolf (2003) for a description of the de jure classification system, as well as historical data on countries' classification under this system.

${ }^{5}$ For an early recognition of this concern, see Edwards and Savastano (1999).

"The hybrid classification-referred to as the "consensus" classification by Ghosh, Gulde, and Wolf (2003)_discards observations in which the de jure classification does not match a de facto one, based on actual exchange rate movements. Effectively, this procedure narrows the sample by 35 percent over the 1970-99 period. termine the de facto flexibility of exchange rate regimes. ${ }^{7}$ In addition, the IMF itself moved to a de facto classification system in 1999. The IMF de facto classification combines available information on the exchange rate and monetary policy framework and authorities' formal or informal policy intentions with data on actual exchange rate and reserves movements to reach a judgment about the actual exchange rate regime. ${ }^{8}$

Despite these advances, analysis sometimes requires a more nuanced characterization of regimes. Countries experiencing episodes of macroeconomic instability often have very high inflation rates, which may be reflected in high and frequent exchange rate depreciation. Classification of such regimes as floating, intermediate, or pegged is problematic because the macroeconomic disturbances could be incorrectly attributed to the exchange rate regime. In addition, in countries with significant parallel foreign exchange markets, where rates differ substantially from official ones, movements in parallel rates rather than in official rates provide a more realistic barometer of underlying monetary policy. In particular, countries with a fixed official rate but with high inflation and a rapidly depreciating parallel rate cannot be considered as having a monetary stance that is consistent with a pegged regime. Moreover, to assess the relationship between regimes and longer-term economic performance, it is helpful to identify longer-term regimes rather than shorter-term spells within a regime, such as the widening of a horizontal band or a onetime devaluation followed by a re-peg. By employing a relatively short horizon over which the de facto regime is assessed, classification algorithms, such as the one employed by Levy-Yeyati and Sturzenegger, can record potentially a large number of regime changes that are related to short periods of disturbances-possibly transient economic or political shocks-and that do not involve a change in the regime itself.

Reinhart and Rogoff's (2004) Natural classification addresses these shortcomings by separating episodes of severe macroeconomic stress and incor-

\footnotetext{
${ }^{7}$ The Levy-Yeyati-Sturzenegger data set, which goes back to 1974, attempts to classify, on an annual basis, about 180 countries in terms of actual flexibility. About one-third of the observations in their sample cannot be classified by their algorithm, however, because of missing data or because the regime was a peg to an undisclosed basket.

${ }^{8}$ See IMF (1999), Section IV, for details. The IMF de facto classification is, in effect, a hybrid classification system that combines data on actual flexibility with information on the policy framework. Using historical data and information on countries' exchange arrangements, Bubula and Ötker-Robe (2002) put together a database containing IMF de facto classifications going back to 1990
} 
porating information on dual/parallel market exchange rates. ${ }^{9}$ Their classification distinguishes regimes that are freely falling as a separate category and, in cases where the dual/parallel exchange rate differs substantially from the official rate, uses movements in the former rate to classify the regime. Also, a five-year horizon is used to gauge the true flexibility of the longer-term exchange rate regime. The Natural classification divides de facto regimes into five coarse categories-fixed, limited flexibility, managed floating, freely floating, and freely falling - and into 14 fine subcategories. The Reinhart-Rogoff data set is comprehensive, covering virtually all IMF members, in most cases, back to 1946 . Hence, it facilitates richer historical analysis of regime distributions, transitions, and performance than other de facto classifications. ${ }^{10}$

Some qualifications should be noted, however, with respect to de facto classifications, including the Natural classification. The absence of exchange rate variability that is used to classify regimes may reflect the absence of real shocks to the economy rather than a fixed exchange rate regime. Reinhart, Rogoff, and Spilimbergo (2003) find, however, that countries that have had relatively stable exchange rates have not been subjected to fewer or smaller terms-of-trade shocks. ${ }^{11}$ Also, de facto classifications are based on past movements of exchange rates as well as other variables. Hence, they are backward looking and do not incorporate information on policy intentions, which may in turn affect economic performance. ${ }^{12}$ This argument cuts both ways, however. Stated, and even informal, exchange rate policy intentions may be forward looking but may also be misleading. ${ }^{13}$ Finally, de facto classifi-

\footnotetext{
${ }^{9}$ The Natural classification relies on a broad set of descriptive statistics and detailed country chronologies of exchange rate arrangements to group regimes. As noted by Reinhart and Rogoff, this is analogous to natural taxonomic schemes in biology, where species are grouped according to their characteristics.

${ }^{10}$ Technical aspects of the fine and coarse versions of the Natural classification system are described in Appendix I, which also contains a summary comparison of the various regime classification systems.

${ }^{11}$ In principle, of course, countries with relatively stable exchange rates may have been subject to fewer or smaller other real shocks, including policy shocks, or to shocks that happened to offset the terms-of-trade shocks they experienced.

${ }^{12}$ For example, de facto classifications (other than that of the IMF) do not distinguish unsuccessful pegs-those regimes where the authorities try to peg the exchange rate but are unable to do so. The IMF de facto classification, by contrast, incorporates information on policy intentions and, in principle, retains a forward-looking element.

${ }^{13}$ This does not mean, of course, that formal announcement of a de facto regime does not affect macroeconomic performance. Indeed, as the results described in Section III indicate, the effect of announcing the true de facto regime has been significant for certain regimes.
}

cations may result in a high frequency of recorded regime transitions because of changes in the pattern of actual exchange rate movements. The Natural classification addresses this issue by employing a five-year horizon to gauge actual exchange rate flexibility. While this helps to distinguish regimes from spells, it limits the Natural classification's ability to detect short-term currency market pressures, such as those that culminated in the CFA franc devaluation in early 1994, that could have longer-term macroeconomic effects. Hence, the Natural classification is not necessarily appropriate for analyzing issues, such as the near-term impact of changes in a country's exchange rate spell. From a global perspective, however, the Natural classification, with its special features and rich historical coverage, has the potential to yield important new insights into the history of regimes and their effect on macroeconomic performance.

\section{Divergence Between Stated and Actual Policies}

Comparison of the de jure and Natural classifications highlights the divergence between stated and actual policies, particularly at the polar extreme of flexibility. Focusing on the broad classification categories over the period 1973-99 (for which there are overlapping data), Figure 2.1 shows that only about half of the observations - where each observation corresponds to a given country's regime in a particular year-were classified in the same broad category under both the de jure and the Natural classifications. The divergence was particularly striking among so-called floating regimes, where only 20 percent were de facto free floats while 60 percent were either intermediate or pegged regimes and another 20 percent had freely falling currencies. ${ }^{14} \mathrm{Al}-$ though almost all de jure hard pegs were in fact operated as hard pegs, fewer than 40 percent of de jure soft pegs were de facto pegs, either hard or soft. About 60 percent of de jure intermediate regimes actually operated as intermediate regimes. ${ }^{15}$

In the 1970s and 1980s, the differences between actual and stated policies reflected to a large extent the prevalence of dual/parallel foreign exchange markets. In the early 1970 s, almost one-half of all countries and one-third of advanced economies had active dual/parallel markets with exchange rates that

\footnotetext{
${ }^{14}$ Unless otherwise noted, all subsequent references to de facto regimes and regimes' actual operations are to the Natural classification.

${ }^{15}$ Surprisingly, during the run-up to the European Monetary Union, all the euro area countries were listed as intermediate regimes in the de jure classification until 1999.
} 


\section{Figure 2.I. Natural Classification Regimes by De Jure Category, 1973-99 \\ (In percent of annual observations)}

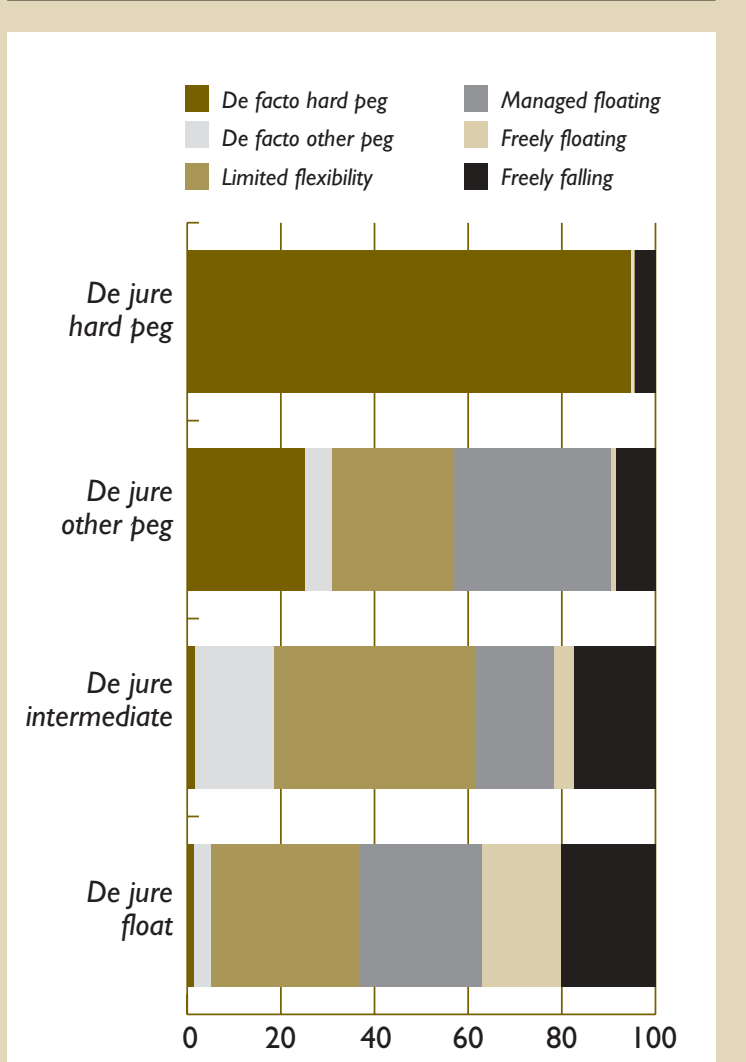

Sources: Reinhart and Rogoff (2004); Ghosh, Gulde, and Wolf (2003); and IMF staff estimates.

deviated substantially from official rates (Figure 2.2). Foreign exchange markets have since been unified in most countries. In emerging markets and other developing countries, the unification occurred mainly in the 1990s as capital flows to emerging market economies accelerated and efforts were intensified by the international community, including the IMF, to encourage countries to accept Article VIII of the IMF's Articles of Agreement. Although the number of countries with dual/parallel exchange rates that deviated substantially from official rates declined to 9 in 2001 from 30 in 1995, 16 the number

\footnotetext{
${ }^{16}$ These data are based on Reinhart and Rogoff (2004), and are not identical to the IMF's classification of unified versus dual/multiple rates. By multiple exchange rates, Reinhart and Rogoff refer to cases where one or more rates is market determined, as opposed to cases where multiple official rates are all fixed and simply act as a differential tax on a variety of transactions.
}

\section{Figure 2.2. Countries with Dual/Parallel Foreign Exchange Markets \\ (In percent of annual observations)}

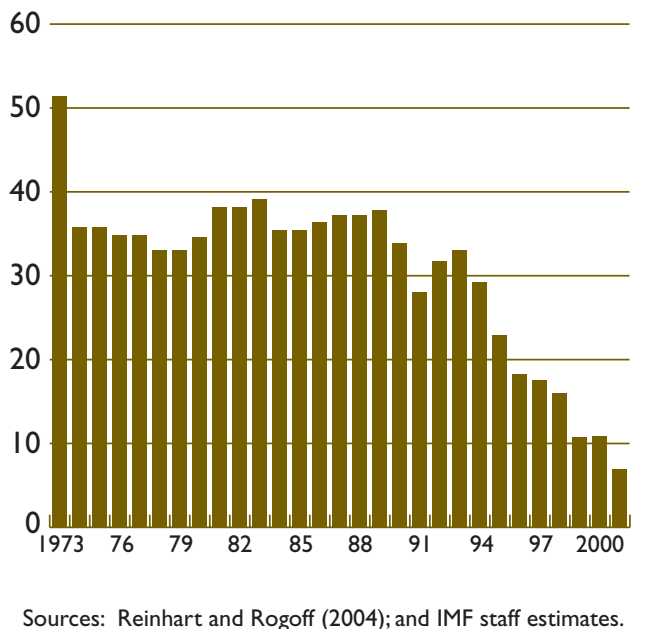

of mismatches between countries' classifications in the de jure and Natural classifications did not. This was due mainly to the increase in freely falling regimes in the 1990s, which included the transition economies of central and eastern Europe and the former Soviet Union, and the de jure classification of euro area currency regimes as intermediate until 1999.

The frequency of freely falling regimes is also on a declining trend, despite a brief resurgence following the breakup of the Soviet Union. Rogoff (2003) notes that this in turn reflects the decline in inflation across the world in recent years. Hence, accounting for dual/parallel markets and free falling regimes, while critical in drawing lessons from the history of regimes, is less likely to be as relevant in the future.

\section{Differences Across Country Groups}

As noted, compared to the Natural classification the de jure classification significantly overstates the number of true floats and pegs, suggesting that fewer countries are at the polar extremes than implied by their announcements. Figures 2.3 and 2.4 show that few countries, especially emerging markets and other developing countries, actually allow

Another important difference is that dual/multiple markets are typically legal, whereas parallel markets may or may not be legal. 


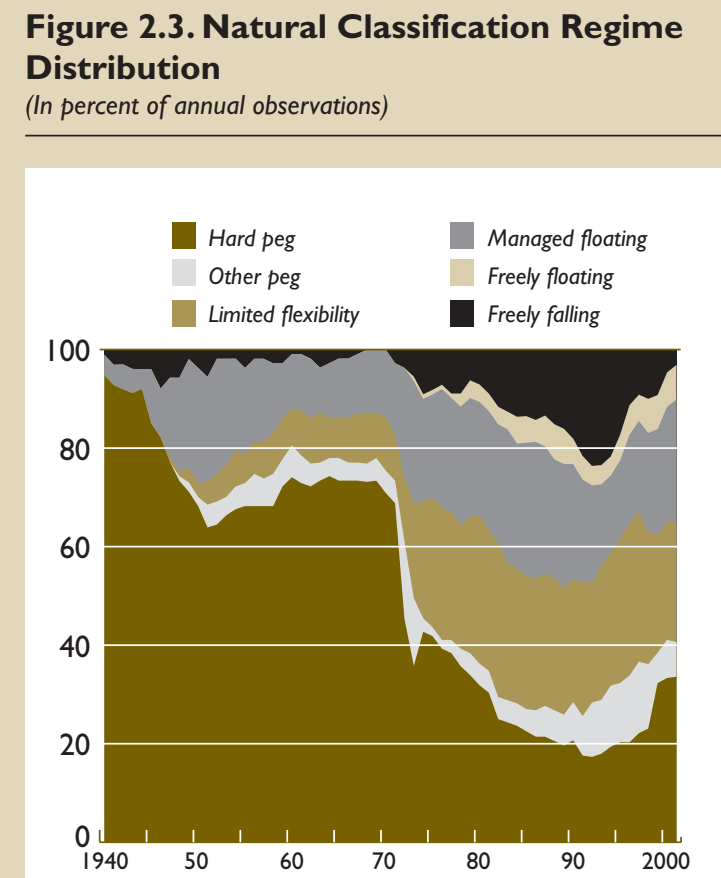

Sources: Reinhart and Rogoff (2004); and IMF staff estimates.

Figure 2.4. De Jure Regime Distribution

(In percent of annual observations)

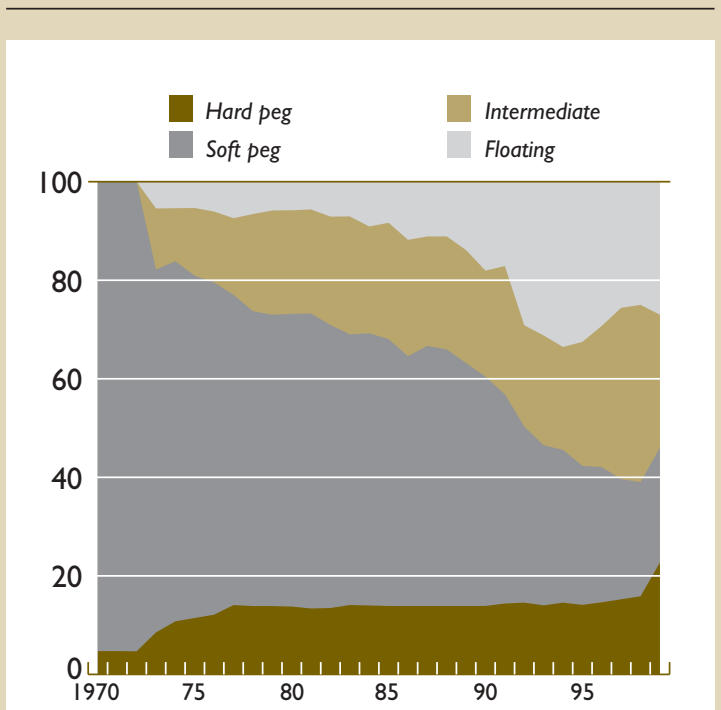

Sources: Ghosh, Gulde, and Wolf (2003); and IMF staff estimates. their exchange rates to float freely. Among emerging markets, the proportion of de facto free floaters has remained relatively small at 4-7 percent since the mid-1980s (Figure 2.5). ${ }^{17}$ Even among advanced economies, only about 20 percent allow their currencies to float freely, although close to 40 percent state that they have floating regimes. These figures also show that fewer countries actually peg their exchange rates than announcements would suggest. De facto pegs accounted for about onethird of all de facto regimes in recent years, while de jure pegs comprised about one-half of all de jure regimes. The number of hard pegs was significantly higher, however, under the Natural classification than under the de jure. ${ }^{18}$ While the proportion of de facto pegs has increased slightly since the early 1990s, this mainly reflects the monetary union in Europe and the adoption of pegs by some of the countries that were previously experiencing freely falling currency values. Interestingly, hard pegs accounted for most of the recent increase in pegs in other developing countries, while soft pegs accounted for much of the increase in emerging markets.

Intermediate regimes have been, and continue to be, considerably more prevalent than suggested by the de jure classification. While de jure intermediate regimes rose to about a quarter of all exchange rate regimes in the late 1990s from around 10 percent in the mid-1970s, the proportion of de facto regimes with an intermediate degree of flexibility has remained at about one-half since the mid-1970s. ${ }^{19}$ Within intermediate regimes, however, managed floats have become more prevalent in emerging mar-

\footnotetext{
${ }^{17}$ For other developing countries, the increase in de jure floats in the late 1980s and early 1990s was in reality a rise in freely falling regimes, and part of the decline in free floats since the mid-1990s reflected a reduction in freely falling currency values as macroeconomic stabilization progressed in many of these countries (e.g., Azerbaijan, Bulgaria, Iran, the Kyrgyz Republic, and Ukraine).

${ }^{18}$ The definition of hard pegs differs slightly across classifications. In the de jure classification, such pegs constitute monetary unions and currency boards. The Natural classification also includes preannounced pegs. Of the 43 countries listed as hard pegs by the Natural classification in 2001, only five had preannounced pegs, of which only one (Malaysia) was in the emerging markets group. Excluding preannounced pegs from the hard peg category does not affect the finding that hard pegs are more prevalent under the Natural classification than under the de jure. The finding of a general absence of a bipolar tendency among emerging markets in the 1990s (discussed below) is actually accentuated by such an adjustment, however.

${ }^{19}$ Among advanced economies, the proportion of intermediate de facto regimes expanded sharply around the time of the collapse of the Bretton Woods system but shrunk steadily in the 1980s and $1990 \mathrm{~s}$ as the euro area countries moved toward monetary union. Among emerging market economies and other developing countries, the proportion of intermediate regimes rose markedly in the 1970 s, but has remained relatively flat since then.
} 
kets over the past decade, while other developing countries have tended to move in the opposite direction toward more limited flexibility.

A historical retrospective using the Natural classification also suggests that the breakup of the Bretton Woods system was much less of a watershed event for emerging markets and other developing countries than for advanced economies. De facto pegs in advanced economies declined sharply as the Bretton Woods system collapsed, while among emerging markets and other developing countries the decline in pegs was more gradual and continued through the 1980s. ${ }^{20}$

Even when compared with other de facto classifications, the Natural classification records fewer regimes near the polar extremes of full flexibility and rigid pegs. At a broad level, the IMF de facto classification yields similar results to the Natural classification - two-thirds or more of Natural classification free floats, pegs, and intermediate regimes are classified the same way by the IMF de facto classification. The IMF classification, however, picks up many more free floats than the Natural classification, especially among emerging markets, where as many as one-third were listed as freely floating regimes in 2001 (Figure 2.6). ${ }^{21}$ Similarly, the prevalence of pegs is higher than in the Natural classification, especially for other developing countries, of which about half were listed as pegged regimes in 2001.22 The Levy-Yeyati-Sturzenegger de facto classification also records many more free floats and pegs and, consequently, many fewer intermediate regimes than the Natural classification (Figure 2.7). Surprisingly, over half of emerging markets are classified as floats in the Levy-Yeyati-Sturzenegger classification in the late 1990s, both before and after the Asian crises, and free floats are more prevalent than in the de jure classification, drawing into question the degree to which the former presents a more accurate picture of actual regimes than the latter.

${ }^{20} \mathrm{As}$ the prevalence of de facto pegged regimes has evolved, the choice of anchor currency among peggers has undergone significant change, with virtually all peggers now anchoring to either the dollar or the euro (Box 2.1).

${ }^{21}$ Of all the observations classified as free floats by the IMF de facto regime that were also classified by the Natural classification, only about 27 percent were classified by the latter as free floats, while 18 percent were freely falling regimes, 33 percent were managed floats, 18 percent were limited flexibility regimes, and 3 percent were pegs. About 30 percent of the IMF de facto free floats were not classified by the Natural classification, usually because qualitative evidence suggested the presence of a significant parallel market, but parallel exchange rate data were not available. That said, Bubula and Ötker-Robe (2002) also find, using the IMF de facto classification, that intermediate regimes have been more prevalent than suggested by the de jure classification.

${ }^{22}$ Among advanced countries, however, euro area economies are listed as limited flexibility regimes rather than pegs in the IMF de facto classification, as they were listed in the de jure classification, until 1999 (until 2001 for Greece).

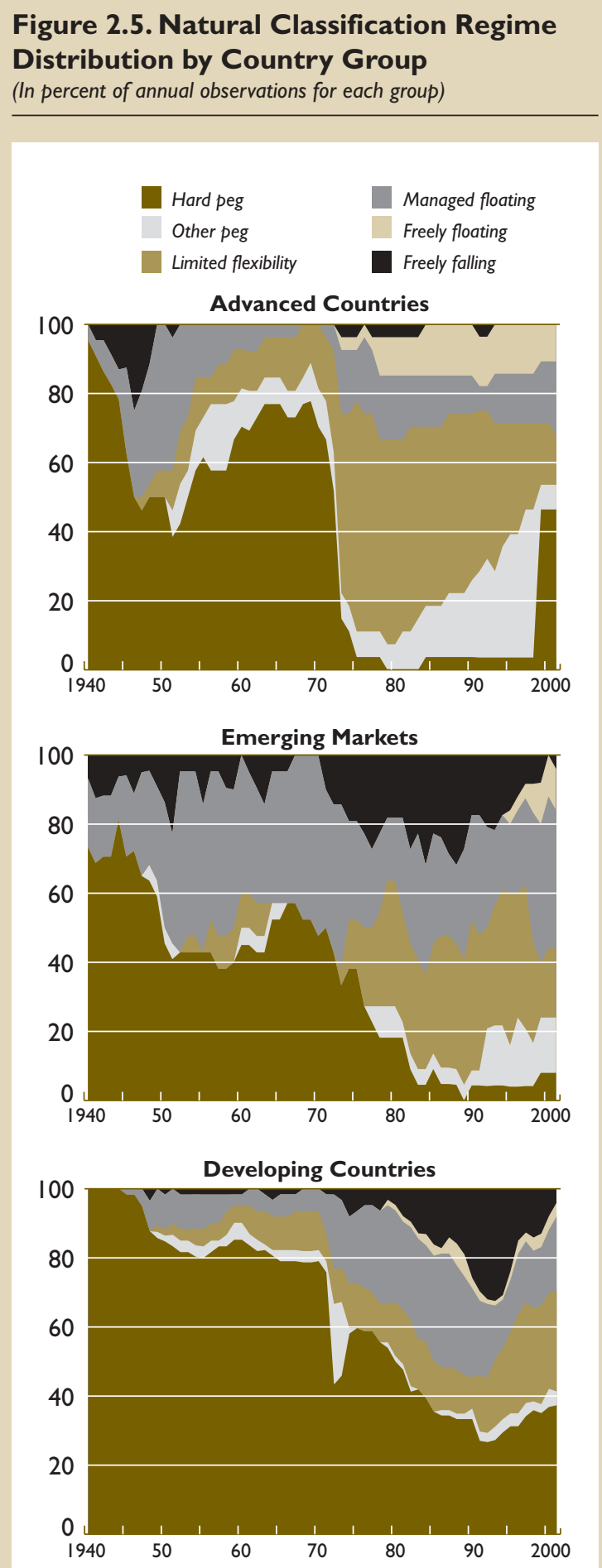

Sources: Reinhart and Rogoff (2004); and IMF staff estimates. 


\section{Box 2.I. Anchor Currency Choice}

While there is a large empirical literature on the conditions under which countries adopt fixed or floating regimes (discussed in Appendix II), less has been written on the determinants of anchor currency choice. The question of interest is: Once countries choose to peg their exchange rates to an anchor currency-including by means of crawling pegs or bands - what determines the choice of this anchor?

The theory of optimal currency areas suggests that countries benefit from adopting the same anchor as a trade partner, because this reduces their bilateral exchange rate variability. Meissner and Oomes (2004) provide empirical evidence of these network externalities. The authors find that, after controlling for other factors-such as country size, openness, and colonial history-the probability of choosing a particular anchor currency increases with the amount of trade with other countries that use this same anchor. These externalities may explain why virtually all countries that have chosen to peg their exchange rates in some way to another currency have converged over the last 50 years to using either the U.S. dollar or the euro as their anchor currency (see figure below).

\section{0-72}

Between 1940 and 1972, the U.S. dollar was the most popular anchor currency chosen by advanced countries, followed by the British pound and the German deutsch mark. For developing countries, the predominant anchor currencies were the U.S. dollar, the British pound, and the French franc, with the latter two choices being determined largely by colonial history.

\section{3-89}

Following the collapse of the Bretton Woods system, the British pound disappeared entirely from the menu of anchor choices. Pegs to the U.S. dollar declined in popularity among advanced countries as an increased number of free and managed floaters emerged, and the majority of advanced countries that retained pegs ended up tying their currencies in some form to the deutsche mark, and later to the euro. Developing countries largely switched to using the U.S. dollar as anchor, except the group of former French colonies that continued to peg to the French franc.

\section{$|990-200|$}

The overall distribution of anchor currencies did not change much in the 1990s, apart from the introduction of the euro in 1999. The behavior of transition economies during this period, however, is illustrative of the dynamics of anchor currency choice. Following the breakup of the Soviet Union in the early 1990s, most transition economies fell initially in the freely falling category for several years, and then increasingly started tying their currencies to the deutsche mark or the U.S. dollar. Interestingly, the choice of anchor was almost perfectly divided among regional lines: while Central and Eastern European countries chose to anchor to the deutsche mark, and later to the euro, most former Soviet Union republics chose the U.S. dollar as their anchor-with the exception of Estonia, which adopted a currency board arrangement with the deutsche mark, and Latvia, which chose the SDR. As Meissner and Oomes (2004) show, this divide between the euro and the dollar cannot be explained solely on the basis of trade flows with Europe or the United States but is partially the result of network externalities arising from trade partners' anchor currency choices.

\section{Anchor Currency Choices}

(In percent of annual observations)

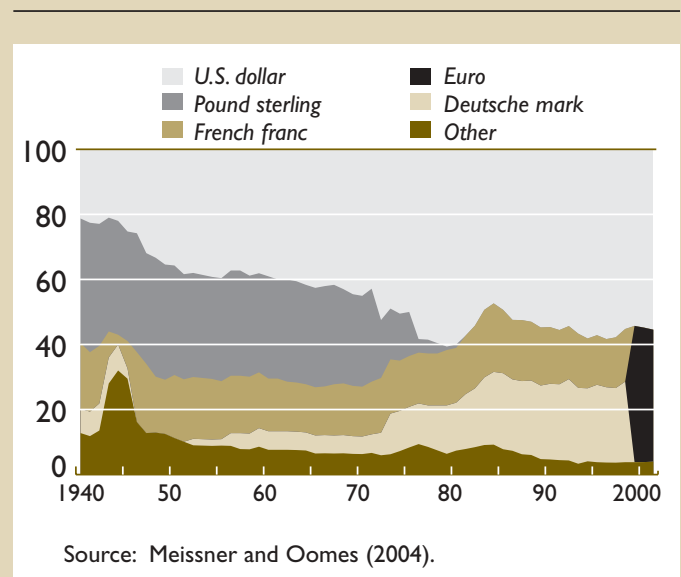

\section{Bipolar Hypothesis and Fear of Floating}

The Natural classification raises questions about the general validity of the bipolar hypothesis. Starting in the mid-1990s, some observers had predicted that emerging market countries would, over time, move to the polar extremes of exchange rate flexibility; that is, they would either adopt freely floating regimes or move to hard pegs. ${ }^{23}$ That speculative attacks against hard pegs were rare and could apparently be warded off seemed to lend support to the

${ }^{23}$ For example, Eichengreen (1994, pp. 4-5) argues that countries "will be forced to choose between floating exchange rates on the one hand and monetary unification on the other." Obstfeld and Rogoff (1995, p. 74) claim that for countries with an open capital 
hypothesis. ${ }^{24}$ The increase in free floats and hard pegs since 1990 in the de jure-and to a smaller extent in the IMF de facto classifications, as illustrated in Figures 2.4 and 2.6, respectively-appeared to support the bipolar view. As noted above, however, the Natural classification indicates that there has been no "hollowing out of the middle." While a few emerging markets indeed moved in the 1990s to de facto hard pegs (Argentina and Malaysia) or free floats (Indonesia, Korea, and South Africa), just as many transitioned from freely falling to intermediate regimes (Brazil, Peru, Poland, Russia, and República Bolivariana de Venezuela). ${ }^{25}$ As a result, the middle remained as large as it was a decade ago. Moreover, transitions since 1990 to de facto pegs among emerging markets have been more in the soft category (China, Egypt, Jordan, and Peru) rather than the hard category. ${ }^{26}$

The tendency of countries to allow less exchange rate flexibility in practice than in policy statements is consistent with the fear of floating. As Calvo and Reinhart (2002) argue, fear of floating - a reluctance to allow exchange rates to fluctuate freelycould arise for various reasons, including policy credibility concerns; fear of Dutch disease in case of large appreciations; and fear of inflation, currency mismatches, and/or balance sheet effects (on account of high liability dollarization) in case of large

account, "there is little, if any, comfortable middle ground between floating rates and the adoption of a common currency." More recently, Summers (2000, p. 8) argued that, for economies with access to international capital markets, "the choice of appropriate exchange rate regime ... increasingly means a move away from the middle ground of pegged but adjustable fixed exchange rates towards the two corner regimes." Fischer (2001, p. 22) concluded on the basis of the IMF de facto classification that "In the last decade, there has been a hollowing out of the middle of the distribution of exchange rate regimes in a bipolar direction, with the share of both hard pegs and floating gaining at the expense of soft pegs."

${ }^{24}$ According to the Natural classification, Brazil, Korea, and Malaysia had limited flexibility regimes prior to their recent capital account crises, while Mexico, the Philippines, and Thailand had de facto pegs (but not hard pegs) before their respective crises. Russia was not classified in 1997-98, while Argentina was classified as a hard peg through 2001. Of all the major recent crisis countries, only Turkey had a managed floating regime prior to its crisis.

${ }^{25}$ Hernandez and Montiel (2001) argue that, while several Asian countries have increased the flexibility of their exchange rates in the postcrisis period, generally they have not adopted truly freely floating regimes.

26Peru was classified as a de facto soft peg during 1999-2001 by the Natural classification on the basis of a two-year rather than a five-year window to allow for a possible structural break in the variability of the exchange rate toward the end of the sample period. Peru would fall just short of the criteria for a de facto peg in 1999-2001 if a five-year window, which would also span the period prior to 1999 , were used.

\section{Figure 2.6. IMF De Facto Regime Distribution}

(In percent of annual observations)

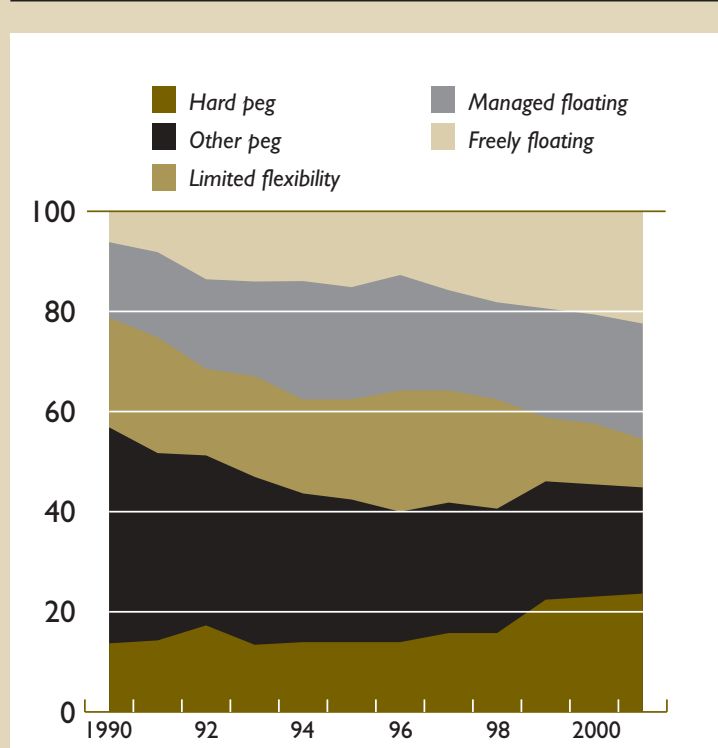

Sources: Bubula and Ötker-Robe (2002); and IMF staff estimates.

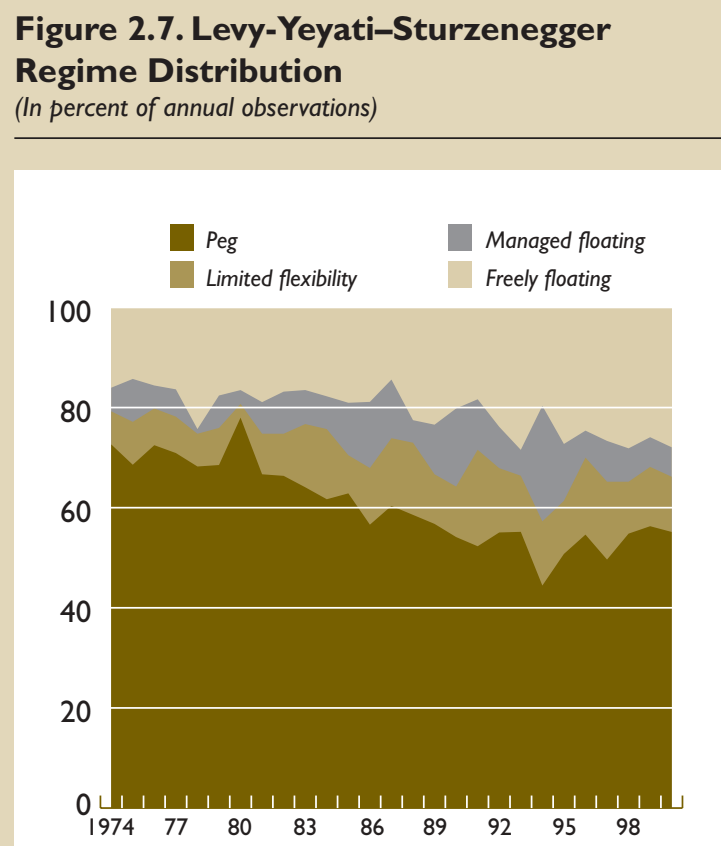

Sources: Levy-Yeyati and Sturzenegger (2003); and IMF staff estimates. 
depreciations. ${ }^{27}$ As Figure 2.1 indicates, the vast majority of countries that say they float actually do not. Moreover, many countries that say they have intermediate regimes in fact have de facto pegs.

\section{Regime Transitions}

Major global and regional events have influenced exchange rate regime transitions. The collapse of the Bretton Woods system in 1973 was, of course, the outcome of pressures built up in a relatively rigid system of exchange rate regimes and was followed by a sharp increase in flexible arrangements (Figure 2.8). The debt crisis of the 1980s and the transformation of the economies of Central and Eastern Europe and the former Soviet Union in the early 1990s were also accompanied by a relatively high frequency of regime transitions, especially into and subsequently out of the freely falling category. In the latter half of the 1990s, as several large emerging markets faced external financing crises, the frequency of exchange rate regime transitions among this group rose once again. Then in 1999, a major transition occurred among advanced economies with the adoption of a monetary union in the euro area.

Once the transitions into and out of the freely falling category - as well as those that occurred as a result of global events-are distinguished, it turns out that the frequency of changes in exchange rate regimes today is remarkably similar to that of 50 years ago. As Figure 2.8 illustrates, the average number of countries transitioning to a different regime (excluding transitions into and out of the freely falling category) in any given year since the collapse of the Bretton Woods system was about the same as during the Bretton Woods period.

Thus, the interesting finding is that countries have changed their de facto exchange rate regime relatively infrequently. On the basis of data going back to the 1940 s, about 7 percent of all countries transitioned to a different regime in an average year, and the typical exchange rate regime had a duration of about 14 years (Table 2.1). If the $1970-75$ period is excluded and Eastern and Central European and for-

\footnotetext{
${ }^{27}$ See also Reinhart (2000). Hausmann, Panizza, and Stein (2001) find that exchange rate volatility declines with the decrease of amounts countries can borrow internationally in their own currency, which the authors consider an indicator of a country's ability to avoid currency mismatches. The extent of exchange rate pass-through turns out to be less significant. Alesina and Wagner (2003) identify conditions under which countries declare a de jure float but, because of fear of floating, restrict exchange rate flexibility.
}

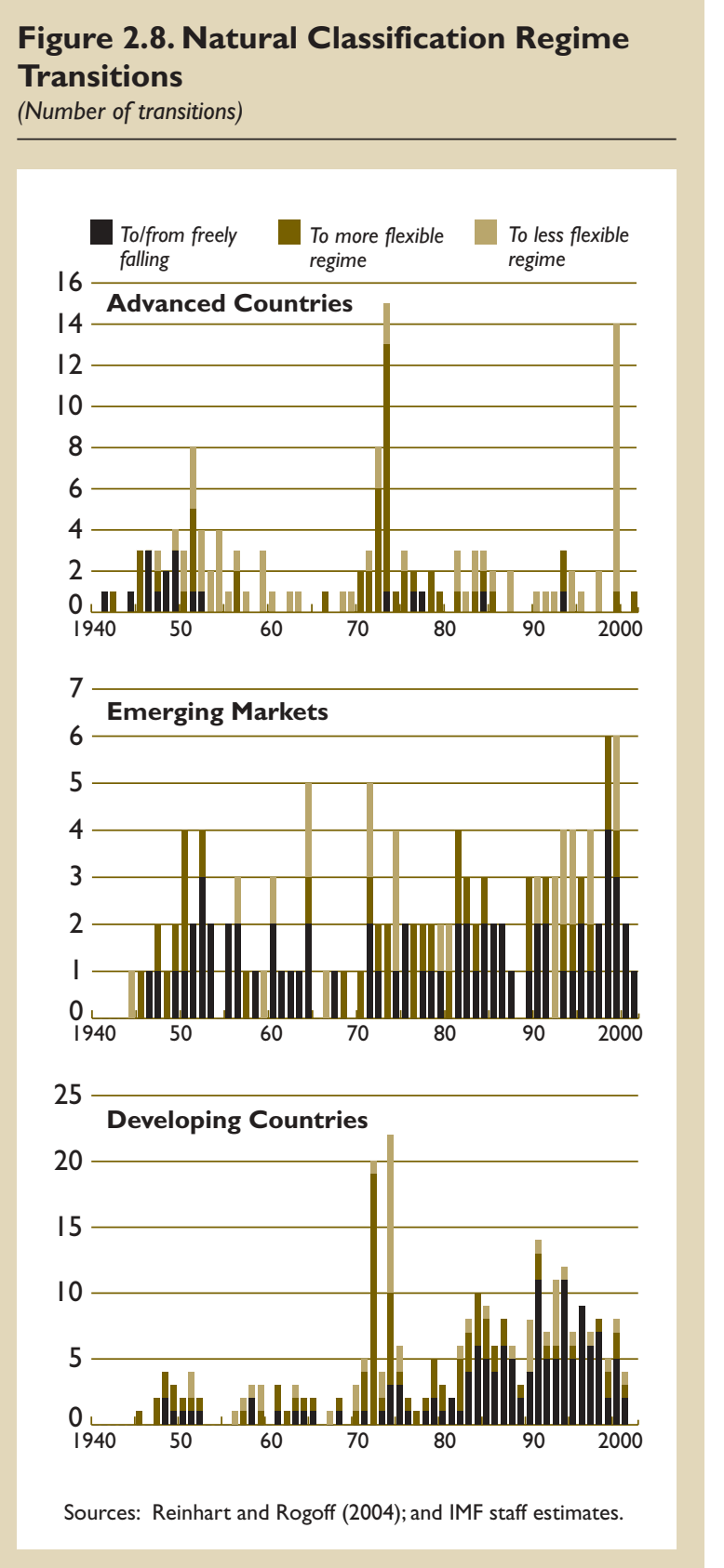

mer Soviet Union countries along with the euro area countries are removed from the sample, transitions were even less frequent. In the adjusted sample, the average regime duration rises to just over 16 years, while the proportion of countries changing regime in any given year declines to about $6 \frac{1}{4}$ percent.

De facto pegged regimes have tended to change less frequently and last longer than other regimes. For all de facto pegs since 1940, the probability of exiting to a different regime in any given year was 
Table 2.I. Annual Transition Probabilities

(Historical rate of regime transitions, in percent)

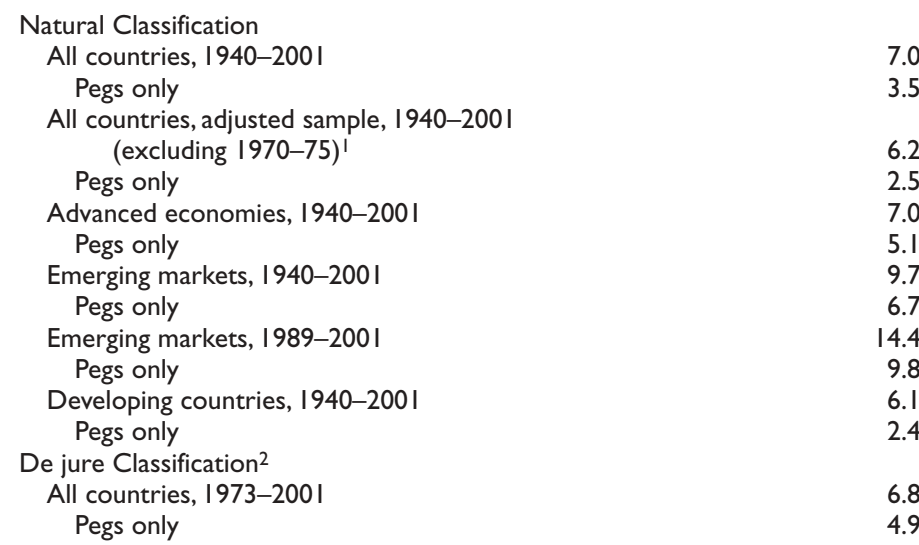

Source: Reinhart and Rogoff (2004); Ghosh, Gulde, and Wolf (2003); and IMF staff estimates

IExcludes euro area and former command economies in Europe and the former Soviet Union.

${ }^{2} \mathrm{Natural}$ classification transition rates for all regimes and pegs over the same period were 9.3 percent and 5.1 percent, respectively.

about $3 \frac{1}{2}$ percent. ${ }^{28}$ Since the Natural classification classifies as pegs only those that are successful, countries that attempt to peg but are able to sustain the peg only briefly tend not to be classified as pegs. This, together with the fact that the Natural classification does not treat onetime devaluations followed by a re-peg as a change in the longer-term regime, ${ }^{29}$ reduces the observed exit rate from de facto pegs. It is also worth noting that regime transitions are less frequent in the de jure classification than in the Natural classification, suggesting that countries tend to change their stated exchange rate policy objectives even less frequently than their de facto exchange rate policies. The average annual exit rate from de facto and de jure pegs during 1973-99 has been about the same; however, this is partly because the collapse of

\footnotetext{
${ }^{28}$ These conclusions contrast with the results obtained by Klein and Marion (1997), Eichengreen and others (1998), and Duttagupta and Ötker-Robe (2003) among others, who find the longevity of pegs to be much shorter. This is mainly because the Natural classification attempts to identify longer-term regimes rather than short-term "spells," which are analyzed in the other studies.

${ }^{29}$ For example, the Natural classification does not treat the 1994 CFA franc devaluation as a change in regime. By contrast, the Levy-Yeyati-Sturzenegger classification, which uses a oneyear horizon to measure the variability of the official exchange rate, picks up significantly more transitions: for example, a switch from peg to "dirty float" for each of the CFA franc zone countries in 1994 with a switch back to peg in 1995 .
}

the Bretton Woods system accounted for a sizable portion of such exits during this period. ${ }^{30}$

Emerging markets, however, have tended to switch regimes more frequently, and have gone into the freely falling category more often, than other countries. Since 1940, the annual regime transition rate among emerging markets has averaged about 10 percent, compared with 7 percent for advanced countries and about 2 percent for other developing countries. On average, about 3 percent of emerging markets, excluding those already in the freely falling category, have transitioned to a freely falling regime every year. By contrast, only 0.5 percent of all advanced countries and less than 2 percent of other developing countries have switched to a freely falling regime in any given year. The transition rate out of pegged regimes among emerging markets has also been higher (about

\footnotetext{
${ }^{30}$ Masson (2001) obtains very similar results for regime transition rates and regime duration using the Ghosh and others (1997) classification, but finds that transitions using the Levy-YeyatiSturzenegger classification are considerably more frequent. Masson suggests that the difference in historical transition rates may arise from sampling problems - a fair number of observations are inconclusive in the Levy-Yeyati-Sturzenegger data and thereby omitted-and methodological differences that tend to accentuate de facto flexibility (and hence transition rates) in the LevyYeyati-Sturzenegger algorithm in periods of heightened exchange market pressures. Using the IMF de facto classification, Bubula and Ötker-Robe (2002) conclude that intermediate regimes are unlikely to disappear in the future.
} 
7 percent) than in advanced and other developing countries (5 percent and $2^{1 / 2}$ percent, respectively). ${ }^{31}$

If historical transition rates continue and no further major global shocks occur, intermediate regimes will remain prevalent in the future, and the overall distribution of de facto regimes will be similar to that at present. Given that pegs have had a somewhat longer average duration than other regimes in the past, the historical transition rates imply that the proportion of pegs could increase slightly over time. Similarly, since relatively few countries, especially developing countries, have had true free floats in the past, the historical likelihood of transitioning into a free float has been low, implying that the share of free floats among all regimes is likely to remain modest in the future. As other developing countries become increasingly integrated into global financial markets, however, their regime transitions may well resemble those seen among emerging markets during the 1990s. In that case, the proportion of pegged regimes among developing countries will tend to decline gradually in the future, while managed floats and free floats will gradually increase. Over the longer term, of course, political economy considerations may guide regime choice decisions in some countries. For example, some may choose to join currency unions in the not-so-distant future. Prospects for transitions of that nature cannot be assessed on the basis of historical transition rates, however, and are clearly beyond the scope of this analysis.

\section{Implications for Assessing Regime Performance}

Empirical analysis seeking to uncover the link between countries' exchange rate regimes and their macroeconomic performance depends critically on how regimes are classified. The wide variation between countries' stated exchange rate regimes and their actual practice suggests that results obtained by employing the de jure classification could be off the mark and that use of a classification that more accurately captures true regime flexibility can lead to different conclusions. The Natural classification, with its special features and historical coverage, is a promising candidate for such analysis. ${ }^{32}$

\footnotetext{
${ }^{31}$ These calculations do not treat switches within the pegged category (e.g., from hard to other pegs) as a transition. The average duration of pegs in other developing countries is strongly affected by the CFA franc zone countries, many of which have retained de facto pegs throughout the sample period.

${ }^{32}$ The issue of causation affects potentially the analysis of regime performance: better macroeconomic performance may be associated with certain regimes because countries with strong performance may choose systematically to adopt those regimes.
}

The persistent popularity of intermediate regimesespecially among emerging markets and other developing countries-as identified by the Natural classification, suggests that such regimes may provide important advantages. Indeed, the absence of a general bipolar tendency may indicate that intermediate regimes are able to capture some of the benefits of both extremes while avoiding many of the costs.

Finally, the relatively long average duration of Natural classification regimes may suggest that regime transitions involve significant costs. The higher transition rates for emerging markets indicate, however, that either these costs decline as countries experience higher capital flows or, more likely, that higher capital flows in the absence of adequate financial infrastructure and safeguards make it harder to sustain regimes, particularly pegged regimes. Again, evidence in support of this channel may be obtained potentially by assessing the (historical) likelihood of crises under alternative exchange rate regimes across different types of economies.

\section{Appendix I. The Natural Classification}

This appendix summarizes the data and algorithm used to construct the Natural classification and provides a brief summary of the main features of various de facto classifications (see Table A2.1).

The Natural classification, which classifies exchange rate regimes into fine and coarse categories (as summarized in Table A2.2), employs monthly data on official and market-determined exchange rates for the period 1940-2001.33 The data on market-determined exchange rates are drawn from various issues of Pick's Currency Yearbook, Pick's Black Market Yearbook, and Pick's World Currency Report, while the official rate data are from the same sources as well as the IMF's International Financial Statistics. The quotes are end-of-month exchange rates. Annual classifications are simply the modal monthly classifications for each country in each year.

The procedure employed by the Natural classification to classify regimes is as follows:

\footnotetext{
As discussed in Appendix II, however, it is difficult to find empirical regularities between a large set of potential determinants of regime choice-including standard measures of the broader policy context—and between countries' actual regimes.

${ }^{33}$ While data on market-determined exchange rates are available only for the period 1946-98, Reinhart and Rogoff (2004) were able to classify most countries for the years 1940-45 and 1999-2001 on the basis of official exchange rate data only because few countries had active parallel markets in those years. Observations where the parallel market was known to be substantial but where parallel rate data were not available are marked "unclassified" by the Natural classification.
} 
Table A2. I. Main Features of Various De Facto Classifications

\begin{tabular}{|c|c|c|c|c|}
\hline & $\begin{array}{l}\text { Ghosh, Gulde, } \\
\text { and Wolf (2003) }\end{array}$ & $\begin{array}{l}\text { IMF (I999, 2003b); Bubula } \\
\text { and Ötker-Robe (2002) }\end{array}$ & $\begin{array}{l}\text { Levy-Yeyati and } \\
\text { Sturzenegger (2003) }\end{array}$ & $\begin{array}{l}\text { Reinhart and } \\
\text { Rogoff (2004) }\end{array}$ \\
\hline Period & 1973-99 & 1990-present & $1974-2000$ & $|940-200|$ \\
\hline Frequency & Annual & Annual and monthly & Annual & Annual and monthly \\
\hline Number of countries & 165 & 190 & 156 & 153 \\
\hline Number of regime types & 25 fine, 9 coarse & I5 fine, 8 coarse & 4 & 14 fine, 5 coarse \\
\hline Advantages & $\begin{array}{l}\text { Uses quantitative and } \\
\text { qualitative information } \\
\text { (survey of IMF desk } \\
\text { economists) } \\
\text { Fine taxonomy }\end{array}$ & $\begin{array}{l}\text { Uses quantitative and } \\
\text { qualitative information } \\
\text { (survey of IMF desk } \\
\text { economists; discussions } \\
\text { with authorities; news } \\
\text { articles; press reports) }\end{array}$ & $\begin{array}{l}\text { Uses information on } \\
\text { volatility of foreign } \\
\text { exchange reserves } \\
\text { Systematic approach; } \\
\text { no judgment needed }\end{array}$ & $\begin{array}{l}\text { Uses dual/parallel exchange } \\
\text { rate information } \\
\text { Separates freely falling } \\
\text { episodes }\end{array}$ \\
\hline & & $\begin{array}{l}\text { All IMF member } \\
\text { countries classified; } \\
\text { classification } \\
\text { continuously updated }\end{array}$ & & $\begin{array}{l}\text { Long time series; monthly } \\
\text { exchange rate movements to } \\
\text { identify regime } \\
\text { Systematic approach; no } \\
\text { judgment needed }\end{array}$ \\
\hline Disadvantages & $\begin{array}{l}\text { Relies to large extent } \\
\text { on stated policy } \\
\text { intentions, which may } \\
\text { deviate substantially } \\
\text { from actual practice } \\
\text { Requires subjective } \\
\text { judgment, which may } \\
\text { differ across countries } \\
\text { and over time } \\
\text { Not all countries are } \\
\text { classified for all time } \\
\text { periods }\end{array}$ & $\begin{array}{l}\text { Requires subjective } \\
\text { judgment, which may } \\
\text { differ across countries } \\
\text { and over time }\end{array}$ & $\begin{array}{l}\text { Exchange rate stability } \\
\text { or reserve changes } \\
\text { may occur for } \\
\text { reasons other than } \\
\text { policy intervention } \\
\text { Reserves data may } \\
\text { not cover derivatives } \\
\text { Many observations } \\
\text { not classified-only } \\
\text { I5 years per country } \\
\text { classified on average } \\
\text { Other countries } \\
\text { affect classification } \\
\text { (due to cluster } \\
\text { analysis) }\end{array}$ & $\begin{array}{l}\text { Exchange rate stability may } \\
\text { occur for reasons other than } \\
\text { policy intervention } \\
\text { A few countries are not } \\
\text { classified for all years }\end{array}$ \\
\hline
\end{tabular}

First, a separation is made between countries with either official dual or multiple rates or active parallel (black) markets.

If there is no dual or black market, a check is done to see if there is an official preannounced arrangement, such as peg, crawling peg, or band. If there is, the announced regime is verified by examining the mean absolute monthly change over the period following the announcement. ${ }^{34}$ If the regime

\footnotetext{
${ }^{34}$ The advantage of using mean absolute deviations, rather than variances or standard deviations, is that this minimizes the impact of outliers. For example, when the exchange rate is fixed but subject to periodic large devaluations, the variance or standard deviation would overstate the extent of exchange rate flexibility in the period around the devaluation.
}

is verified according to rules analogous to those described in step 3 below, it is then classified according to the announcement. ${ }^{35}$

If there is no preannounced exchange rate path, if the announced regime cannot be verified by the data (which is often the case), and if the 12-month rate of inflation is below 40 percent, the regime is classified on the basis of actual exchange rate behavior as follows:

\footnotetext{
${ }^{35}$ When the announced regime is a peg to an undisclosed basket of currencies, tests are done to see if the basket peg is really a de facto peg to a single dominant currency (or to the SDR). If no dominant currency can be identified, the episode is not labeled as a peg. While this suggests that the Natural classification could miss some de facto basket pegs, Reinhart and Rogoff (2004) argue that this is almost certainly not a major issue.
} 
Table A2.2. Natural Classification Categories

\begin{tabular}{|c|c|c|}
\hline Fine & Coarse & Description \\
\hline 1 & I & No separate legal tender \\
\hline 2 & I & Preannounced peg or currency board arrangement \\
\hline 3 & I & Preannounced horizontal band that is narrower than or equal to \pm 2 percent \\
\hline 4 & 1 & De facto peg \\
\hline 5 & 2 & Preannounced crawling peg \\
\hline 6 & 2 & Preannounced crawling band that is narrower than or equal to \pm 2 percent \\
\hline 7 & 2 & De facto crawling peg \\
\hline 8 & 2 & De facto crawling band that is narrower than or equal to \pm 2 percent \\
\hline 9 & 3 & Preannounced crawling band that is wider than or equal to \pm 2 percent \\
\hline 10 & 3 & De facto crawling band that is narrower than or equal to \pm 5 percent \\
\hline II & 3 & $\begin{array}{l}\text { Moving band that is narrower than or equal to } \pm 2 \text { percent (i.e., allows for both } \\
\text { appreciation and depreciation over time) }\end{array}$ \\
\hline 12 & 3 & Managed floating \\
\hline 13 & 4 & Freely floating \\
\hline 14 & 5 & Freely falling \\
\hline 15 & 6 & Dual market in which parallel market data are missing \\
\hline
\end{tabular}

- If the absolute monthly percent change in the exchange rate is equal to zero for four consecutive months or more, that episode is classified (for however long it lasts) as a de facto peg, if there are no dual or multiple exchange rates in place. ${ }^{36}$

- If the probability is 80 percent or higher that the monthly exchange rate change remains within a plus/minus 1 percent band over a rolling fiveyear period, then the regime is classified as a de facto peg or crawling peg over the entire fiveyear period. If the exchange rate has no drift, it is classified as a fixed parity; if a positive drift is present, it is labeled a crawling peg; and, if the exchange rate also goes through periods of both appreciation and depreciation, it is a moving peg.

- The approach regarding de facto bands, as well as preannounced bands, follows a parallel two-step process. Thus, if there is more than an 80 percent probability that the monthly exchange rate change remains within a plus/minus 2 percent band over a rolling five-year period, then the regime is classified as either a de facto narrow band, a narrow crawling band, or a moving band throughout the entire period during which it remains continuously above the 80 percent threshold.

\footnotetext{
${ }^{36}$ This allows for the identification of relatively short-lived de facto pegs as well as those with a longer duration. For instance, this exercise allowed for identification of the Philippines' de facto peg to the U.S. dollar during 1995-97 in the run-up to the Asian crisis, as well as the numerous European de facto pegs to the deutsche mark prior to 1999 .
}

If the 12-month rate of inflation exceeds 40 percent, the episode is classified as freely falling. ${ }^{37}$

The remaining regimes-those that have not already been classified by steps one through four-become candidates for managed or freely floating. To distinguish between the two, the degree of exchange rate flexibility is measured by a composite statistic.

\section{Appendix II. Determinants of Exchange Rate Regime Choice}

The Natural classification data show some links between de facto regime flexibility and certain macroeconomic and financial variables, such as trade openness and dollarization. A review of the literature suggests, however, that it is difficult to find empirical regularities between potential exchange rate regime determinants and actual regimes that hold consistently across all countries, time periods, and regime classifications. Systematic robustness checks of the determinants of regime choice employing the Natural classification support this result.

\section{Macroeconomic and Financial Characteristics of Regimes}

Optimum currency area (OCA) theory holds that variables, such as large size and low openness to

\footnotetext{
${ }^{37}$ In the rare cases where inflation is over 40 percent but the market rate nevertheless follows a confirmed, preannounced band or crawl, the preannounced regime takes precedence.
} 
trade, are likely to be associated with floating exchange rates. One reason for this may be that trade openness raises the transactions benefits from common currencies, and should be expected to lead, therefore, to a decline in the number of independent currencies. The data appear to support the OCA theory prediction that countries that trade a lot will tend to have less flexible exchange rate regimes. Advanced economies that have a high trade openness ratio have tended to have pegged regimes, while the prevalence of free floats has been notably higher in advanced countries with low external trade ratios, such as Australia, Japan, and the United States. A similar pattern holds among other developing countries, where the prevalence of managed floats has been markedly higher and pegs significantly lower in the countries that rely less on external trade. The pattern among emerging markets has been less clear, although relatively closed economies in this group have had a much higher likelihood of being in the freely falling category.

Higher dollarization appears to be associated with less flexible exchange rate regimes among emerging markets, consistent with fear of floating. Fear of floating appears to be stronger in highly dollarized emerging markets, where pegged regimes are more prevalent, than in less-dollarized countries in the group. Conversely, emerging markets with low and medium degrees of dollarization are more likely to have managed or freely floating regimes. Fear of floating does not explain, however, why other developing countries with high dollarization ratios appear to prefer regimes with limited flexibility to pegs. A possible explanation for this could be that many of these countries became highly dollarized following a freely falling episode and lacked the credibility necessary to defend a peg. A regime with limited flexibility allowed them to obtain the benefits of a relatively stable currency, while at the same time maintaining some ability to adjust to shocks.

There is little systematic relation, however, in the degree of capital account openness across de facto regimes. Emerging markets and other developing countries tend to have more capital controls and lower capital flows in relation to GDP than advanced economies. Nevertheless, the variation in capital account openness does not appear to be related to the flexibility of countries' currency regimes. Among advanced economies, the volume of capital flows in countries with de facto pegged regimes tends to be higher than in those with intermediate regimes and significantly higher than in those with freely floating regimes. The relationship is more mixed, however, for emerging markets and other developing countries, possibly because capital controls are often ineffective, so the expected inverse relation between controls and observed capital flows may not hold.

\section{Empirical Findings on Factors Affecting Regime Choice}

Systematic prediction of exchange rate regime choice is elusive. A review of a reasonably broad collection of previous studies shows that different empirical studies using the de jure and other de facto regime classifications have often obtained different results, suggesting that it is very difficult to draw general conclusions about how countries choose their exchange rate regimes. Although certain characteristics have been shown to be important in determining exchange rate regime choice in some groups of countries, and certain characteristics may distinguish countries in some regimes from those in different regimes, no result appears fully robust to changes in country coverage, sample period, estimation method, and exchange rate regime classification.

Several empirical studies have analyzed the determinants of exchange rate regime choice in a cross section of countries. Among the first studies of this kind are Heller (1978), which analyzes the determinants of exchange rate regimes with data from the mid-1970s, soon after the generalized floating that followed the breakup of the Bretton Woods system, as well as Dreyer (1978); Holden, Holden, and Suss (1979); Melvin (1985); Bosco (1987); Savvides (1990); Cuddington and Otoo (1990 and 1991); Rizzo (1998); and Poirson (2001). Some studies, such as those by Collins (1996), Edwards (1996 and 1999), and, more recently, Frieden, Ghezzi, and Stein (2001), have used random effects panel data to analyze also the determinants of changes in exchange rate regime. As such, they can be seen as somewhat related to the recent literature on predicting exchange rate crises. Nevertheless, these studies are included in this review because they report findings on the role of country characteristics that are relatively stable over time (such as openness) in determining exchange rate regime choice. Another recent study, by Berger, Sturm, and de Haan (2000), uses panel data in an attempt to identify the long-run determinants of exchange rate regime choice. Additional studies addressing changes in exchange rate regimes include Masson (2001), Klein and Marion (1997), and Duttagupta and Ötker-Robe (2003).

The vast majority of previous studies have attempted to explain countries' de jure exchange rate regime choice. A few studies have constructed and used measures of the degree of de facto flexibility on the basis of the actual observed volatility of exchange rates and reserves, including Holden, Holden, and Suss (1979) and, more recently, Poirson (2001). Table A2.3 summarizes the approaches and findings of these studies with regard to the impact of several variables on observed exchange rate regime choice. Most studies considered some of the 
II THE EVOLUTION OF EXCHANGE RATE REGIMES: A FRESH LOOK

Table A2.3. Studies on Determinants of Exchange Rate Regimes (Likelihood to Float)

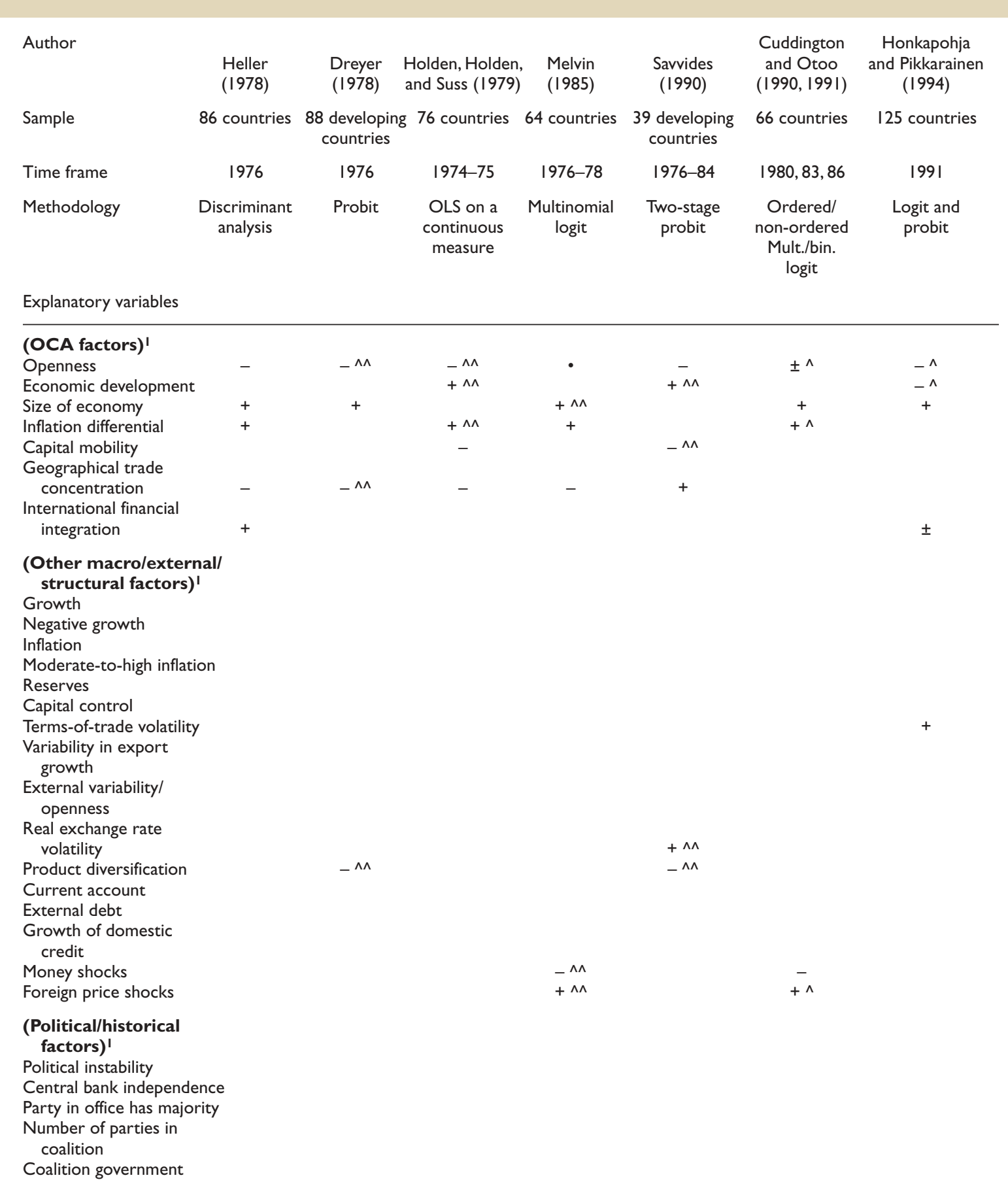




\section{Table A2.3 (concluded)}

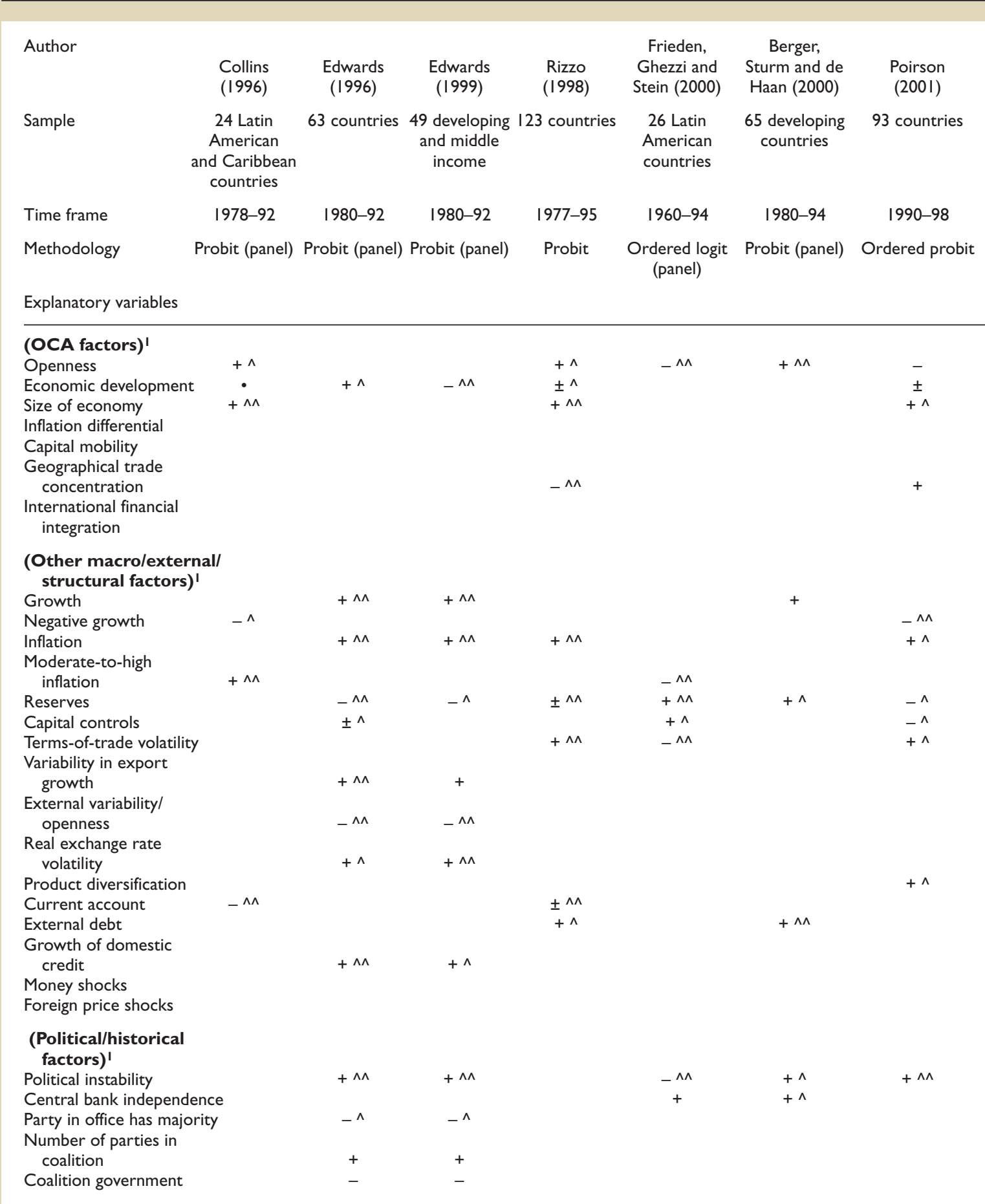

$1+$ indicates that the coefficient of explanatory variable is positive and - that it is negative; \pm indicates the coefficient is either positive or negative depending on the specification or method used; ${ }^{\wedge} \wedge$ indicates the coefficient is statistically significant in most cases; ${ }^{\wedge}$ indicates the coefficient is statistically significant in some specifications; and - indicates not significant but sign not reported by the author. 
optimum currency area variables, such as trade openness (typically measured as imports plus exports, divided by GDP), the size of the economy (gross domestic product in common currency), the degree of economic development (GDP per capita), and geographical concentration of trade (the share of trade with the country's main partner). Among macroeconomic variables, several studies included inflation (whether the country's own inflation or inflation in excess of partner countries) and foreign exchange reserves. Many studies included an indicator of either capital controls, which were typically also drawn or constructed from the IMF's Annual Report on Exchange Arrangements and Exchange Restrictions, or de facto capital openness (e.g., the ratio of foreign assets of the banking system to the money supply). Some studies included measures of volatility of domestic output, exports, domestic credit, or the real exchange rate, although no two studies seem to have looked at the same measure of volatility. A few studies considered variables related to political economy or institutional strength. Most studies analyzed some variables that were not included in any preceding (or subsequent) studies. Collectively, the studies considered more than 30 potential determinants of exchange rate regime choice. (Only the variables considered by more than one study are included in Table A2.3.)

No result appears to be reasonably robust to changes in country coverage, sample period, estimation method, and exchange rate regime classification. For example, openness - the most frequently analyzed variable - is found to be significantly associated with floating regimes by three studies, significantly associated with fixed exchange rates by three studies, and not significantly associated with any particular exchange rate regimes by another five studies. Per capita GDP is found to be significantly associated with floating regimes by three studies, significantly associated with fixed exchange rates by two studies, and not significantly associated with any particular exchange rate regime by another three studies.

There are a few possible exceptions, notably size of the economy and inflation. Size of the economy turns out to be positively associated with floating in almost all studies, though not always significantly. Inflation is almost always positively and significantly associated with floating. In the case of inflation, however, there are serious questions regarding the functional form of the relationship. In a number of studies, the authors use the inflation rate or the inflation differential rather than their logarithms or similar transformations, leaving open the possibility that the results might be driven by a few influential observations. Moreover, Collins (1996) finds that high inflation affects exchange rate regime choice in the opposite direction than that of low/moderate inflation, and significantly so.

New empirical tests using the Natural classification confirm that it is difficult to explain how countries choose their exchange rate regimes on the basis of simple empirical regularities. These results are consistent with previous work based on other exchange rate regime classifications (Juhn and Mauro, 2002). For a number of potential determinants of regime choice-including economic size, trade openness, and capital controls - the variation across regimes is statistically significant. With the possible exception of economic size and trade openness, however, none of the variables is consistently significant across varying specifications in probit and multinomial logit regression analysis. This suggests that the macroeconomic, structural, and institutional variables postulated in various theories are not robust predictors of exchange rate regime choice. Of course, this does not preclude the potential importance of certain variables for specific groups of countries, in certain time periods, or across some of the regime categories. 


\section{Regime Performance: Inflation and Business Cycles}

$\mathbf{H}^{2}$ ow does economic performance differ across exchange rate regimes? Since theoretical predictions are varied and often conflicting, this section explores the question empirically for the period 1970 to 1999 using the Natural classification of de facto exchange rate regimes. This section offers an overarching conclusion while recognizing the limitations of such analyses-in particular, the possibility that economic performance influences the choice of regimes as much as regimes influence performance and that characterizing regimes is inherently difficult because a country's unique history of regimes may be more relevant for economic outcomes than merely the ongoing regime. The findings suggest that exchange rate flexibility becomes more valuable as countries mature in terms of their access to international capital markets and as they develop sound financial systems. Below are three country groupings, each of which responds differently to exchange rate flexibility.

- In developing countries, with their low exposure to international capital movements, relatively rigid regimes, such as pegs and intermediate flexibility arrangements, appear to have enhanced policy credibility and thus have helped achieve lower inflation at little apparent cost in terms of lost growth, higher growth volatility, or more frequent crises. The superior performance of pegged regimes required commitment, as shown through public announcement of that goal, and was further improved through consistent macroeconomic policies that allowed for longer regime duration.

- In contrast, for emerging markets, with their higher exposure to international capital flows, the rigidity of regimes, particularly in the 1990s, was associated with more frequent banking crises and especially costly "twin" crises that included both financial sector and balance of payments turbulence. Moreover, rigid systems were not associated with obvious gains in terms of lower inflation or higher growth. At the same time, the move to full flexibility was inhibited by the concern that large swings in exchange rates could have adverse consequences. Case studies illustrate a variety of approaches to achieving greater flexibility.

- In advanced countries, free floats registered faster growth than other regimes without incurring higher inflation. This benefit may reflect the typically more pronounced nominal rigidities in mature economies, giving flexible exchange rates an important role in reallocating resources following real shocks. Moreover, with financial maturity, widespread availability of debt denominated in domestic currency and in hedging instruments reduces the adverse consequences from currency mismatches that give rise to the fear of floating.

Though on average the value of exchange rate flexibility was found to increase with financial maturity, the results also suggest that the performance of any regime can be enhanced by consistent macroeconomic management. In particular, unified exchange rate systems have been associated with superior performance, and the declining trend of regimes with dual exchange rates that depart substantially from official rates (noted in Section II) is, therefore, a welcome one. Similarly, freely falling regimes, characterized by dysfunctional macroeconomic policies, have also been poor performers. The good news, once again, is that the incidence of freely falling regimes has declined steadily over the past decade. Furthermore, in developing and emerging economies the intermediate regimes-those lying between the two poles, or the two corners of pegs and free floats-have not fared systematically worse than the polar regimes, which is consistent with their longevity (also described in Section II).

The section is organized as follows. First, results of earlier empirical analysis are summarized, followed by a brief summary of the analytical issues to help interpret the results. Next, the study takes a first look at inflation, growth, growth volatility, and the incidence of crises across different exchange rate regimes, but does so without controlling for other factors that affect economic performance. It then controls for other determinants of economic performance and thus at- 
tempts to isolate the conditional relationship between exchange rate regimes and economic performance. Following is an assessment of whether the credibility underlying different exchange rate regimes can be enhanced through announcement of the regime and through policies that allow for longer regime duration, and includes case studies on how emerging markets can enhance their ability to effectively float their currencies. A recap concludes the section. An appendix summarizes the data and the econometric results discussed in this section.

\section{Summary of Empirical Analysis of Exchange Rate Regimes}

In guiding exchange rate regime choice, economic theory has proved to be an insufficient guide for policymakers. Empirical clarification is, thus, crucial. In part, theoretical ambiguity arises because the effects of particular regimes operate with varying strength in different economies. In empirical analysis, therefore, country types need to be distinguished, and this study contrasts the performance of regimes in developing economies, emerging markets, and advanced economies. Emerging markets, the subject of much of the recent policy discussion, differ from developing economies in terms of their higher exposure to international capital flows, but they continue nevertheless to exhibit important institutional and financial sector weakness. As a consequence, emerging markets face higher inflation, greater risk of debt unsustainability, more fragile financial systems, and higher propensity to macroeconomic volatility. Therefore, the emerging markets are characterized by more serious problems of credibility in the formulation of economic policy (see, for example, Fraga, Goldfajn, and Minella, 2003).

A more fundamental ambiguity arises in evaluating exchange rate regimes, where theoretical predictions lead to opposing conclusions. For example, while pegged regimes are generally thought to lower inflation, they may only postpone its manifestation. The growth effects of regimes depend on what is assumed about the shock-absorbing capacity of different regimes and how important these shock absorbers are in raising investment and productivity. Also, flexible exchange rates may dampen the volatility resulting from real external shocks, but this very flexibility may add to the volatility, with adverse economic consequences that lead to a fear of floating (Calvo and Reinhart, 2002).

Empirical analysis, however, has not delivered clear results either. In a well-known contribution, Baxter and Stockman (1989) compare the time-series behavior of key economic aggregates during and after the Bretton Woods system and finds that, aside from greater variability of real exchange rates under flexible systems, there is little difference in the behavior of key macroeconomic aggregates across different exchange rate arrangements. Mussa (1986) had reached similar conclusions earlier. Indeed, in their review of the literature up to that point, Edison and Melvin (1990) despair that the empirical effort to contrast economic performance across exchange rate regimes would ultimately prove inconclusive.

A recent generation of papers offers a more nuanced assessment. Using data for the post-Bretton Woods era for over 100 countries, the analysis initiated by Ghosh and others (1997) culminated in the comprehensive contribution of Ghosh, Gulde, and Wolf (2003). These works deal with several empirically difficult issues. While they rely primarily on the de jure regime classification, they do make some effort to distinguish between the regime announced by national authorities and the one actually practiced. They also consider the perennially hard question of the direction of causality: do exchange rate regimes lead to particular macro outcomes or does performance determine the choice of regimes? Another important contribution is that by Levy-Yeyati and Sturzenegger (2002), who develop a different measure of de facto regimes (as discussed in Section II) and also attempts to deal with the causality issue.

The results of these studies, however, continue to conflict with each other, reflecting the differences in their methods of classifying regimes. Ghosh, Gulde, and Wolf (2003) find that inflation under fixed exchange rate regimes is significantly lower than under intermediate or freely floating arrangements, due to greater confidence in the currency (a credibility effect) and lower money growth (a discipline effect), and that the benefit of pegged exchange rate regimes in terms of inflation performance is fairly robust to the endogeneity of regime choice. The study does not find evidence of a strong link between exchange rate regimes and economic growth, however, especially after controlling for country-specific effects and possible simultaneity bias. This result contrasts with Levy-Yeyati and Sturzenegger (2002), who use a de facto classification of regimes and finds for a similar sample that flexible exchange rates are associated with higher growth in developing countries-which includes the groups of countries referred to in this study as emerging markets. No similar association exists among industrial countries. Both Ghosh, Gulde, and Wolf, and Levy-Yeyati and Sturzenegger find, however, that fixed exchange rate regimes are associated with somewhat higher output volatility. ${ }^{38}$

\footnotetext{
${ }^{38}$ Several missing and inconclusive observations in the LevyYeyati-Sturzenegger classification raise concerns about their conclusions (see Section II).
} 
Against that background, this section reexamines the link between exchange rate regimes and economic performance along four dimensions: inflation, output growth, growth volatility, and the incidence of crises. The assessment is based on the recently constructed Natural classification, which identifies the prevailing de facto exchange rate regime as noted in Section II. The relative longevity of regimes under the Natural classification renders the reverse causality problem less serious than, for example, under the Levy-Yeyati-Sturzenegger classification, where regime classifications change as often as every year. Nevertheless, the section undertakes supplementary analysis to assess if the findings are robust to the reverse causality concern. Also, to allow for the possibility that the pressures under a particular regime are manifested after its collapse in a new regime, the section examines the lagged influence of regimes so that, in effect, the performance in the first year of a new regime continues to be attributed to the previous regime. This turns out to be important in the analysis of volatility in emerging markets. In addition, regime announcement and duration are considered as factors that may influence regime performance. The analysis covers up to 158 countries from 1970 to 1999 , throughout which developing, emerging, and advanced economies are distinguished. Where appropriate, the 1990s, which was a period of rapidly rising capital flows, is distinguished from earlier years.

\section{Analytical Considerations}

An important prediction from economic theory is that exchange rate pegs act as a disciplining device, allowing policymakers in countries with a propensity for high inflation to import credibility and, hence, lower inflation from abroad (Giavazzi and Giovannini, 1989; and Dornbusch, 2001). As a policy prescription, nominal exchange rate rigidity-or an exchange rate anchor-came back into favor in the late 1980s and early 1990s, especially in Latin America, where exchange rate-based stabilizations were viewed as particularly helpful following a history of high inflation (Edwards, 2001). In this line of reasoning, the harder the peg, the more effective it is in enhancing credibility (Edwards and Magendzo, 2003a).

The proposition that pegs provide an inflation advantage is far from universally held, however. For advanced economies, pegged exchange rate regimes should not be necessary for achieving credibility. Even where such regimes could play a role, achieving and maintaining hard pegs is not a straightforward process. In particular, as exposure to international capital flows increases, a larger fraction of the monetary aggregates must be backed to maintain the peg. Hence, emerging markets are less likely to be able to import credibility than are other developing countries whose interaction with international capital markets is more limited. Tornell and Velasco (2000) raise the possibility that the inflationary gains from fixed regimes are illusory. No exchange rate system, the authors argue, can ultimately act as a substitute for sound macroeconomic policies. Far from exerting discipline, fixed exchange rate regimes may create an incentive for governments with short time horizons to cheat, delivering temporarily higher growth through larger deficits, with the full inflationary cost of such policies borne out following the eventual collapse of the peg.

The theoretical implications of exchange rate regimes for economic growth and volatility are similarly murky, with various opposing claims. ${ }^{39}$ In favor of pegs, Dornbusch (2001) argues that lower inflation associated with rigid exchange rate regimes would reduce interest rates and uncertainty, spurring investment and growth. ${ }^{40}$ Also, when a country ties its currency tightly to that of another through a currency board arrangement, transaction costs may be lowered, thereby increasing trade between the two countries. Frankel and Rose (2002) find that such expansion of trade is not offset by diversion away from other trade partners and that by increasing the openness of the economy this form of exchange rate rigidity also raises output growth. An argument in favor of exchange rate flexibility is the possibility of rapid resource reallocation following real shocks when short-run price rigidity is significant (LevyYeyati and Sturzenegger, 2003). Broda (2001) finds evidence that terms-of-trade shocks are amplified in countries that have more rigid exchange rate regimes. Edwards and Levy-Yeyati (2003) take that empirical analysis one step further and concludes that the inability of rigid regimes to absorb such shocks translates, in practice, into lower growth. Similarly, Calvo (1999) argues that the need to defend a peg following a negative external shock may result in high real interest rates and also stifle growth.

While flexible exchange rate regimes may, in principle, dampen real shocks to the economy, could the very flexibility of the exchange rate introduce a new element of volatility? As noted above, a robust finding is that nominal exchange rate volatility is associ-

\footnotetext{
${ }^{39}$ For a useful summary, see Bailliu, Lafrance, and Perrault (2002).

${ }^{40}$ Such a beneficial outcome may have prevailed in the postconvertibility Bretton Woods period from 1959-71, when inflation and exchange rate volatility were low and growth was relatively strong (Bordo, 2003). It is not clear, however, whether this was the consequence of the rigidity in exchange rate regimes or the consequence of a generally favorable economic environment.
} 
Table 3.I. Economic Performance Across Exchange Rate Regimes

\begin{tabular}{|c|c|c|c|c|}
\hline & Inflation & Growth & Volatility & Crisis \\
\hline Fixed & $\begin{array}{l}\text { May enhance monetary } \\
\text { policy credibility and lower } \\
\text { inflation; emerging markets } \\
\text { less likely to be able to } \\
\text { import credibility; inflation, } \\
\text { moreover, may be "bottled } \\
\text { up" under weak macro- } \\
\text { economic management }\end{array}$ & $\begin{array}{l}\text { May reduce transaction } \\
\text { costs, and raise trade } \\
\text { and growth; may also } \\
\text { reduce interest rates and } \\
\text { uncertainty, also raising } \\
\text { investment and growth }\end{array}$ & $\begin{array}{l}\text { May increase volatility in } \\
\text { the presence of real } \\
\text { shocks and nominal } \\
\text { rigidities }\end{array}$ & $\begin{array}{l}\text { High risk of speculative } \\
\text { attacks against currency, } \\
\text { especially when exposed } \\
\text { to volatile capital flows; } \\
\text { susceptibility to banking } \\
\text { sector distress }\end{array}$ \\
\hline Flexible & $\begin{array}{l}\text { Declining importance of } \\
\text { "imported" credibility with } \\
\text { stronger institutions and } \\
\text { financial sectors }\end{array}$ & $\begin{array}{l}\text { Higher growth due to } \\
\text { shock absorbers and } \\
\text { fewer distortions following } \\
\text { real shocks }\end{array}$ & $\begin{array}{l}\text { Possible spilling over of } \\
\text { real exchange rate } \\
\text { volatility into real activity }\end{array}$ & $\begin{array}{l}\text { Low risk of currency } \\
\text { crises and banking crises }\end{array}$ \\
\hline
\end{tabular}

ated with high real exchange rate volatility. Rogoff (1999) argues that such variability does not, in practice, have significant effects on output and consumption in advanced economies but may be harmful in developing countries. Even if the higher volatility has harmful effects, however, pegged regimes may not be the appropriate policy response because the volatility may only appear to be contained and may have real (adverse) effects on private investment due to the greater uncertainty over regime sustainability.

Indeed, just as the inflation-reducing benefits of exchange rate rigidity were being emphasized in the early 1990s, a fundamental reevaluation of the policy prescription was under way following the early crises associated with rigid regimes. For early recognition of this concern, see, for example, Eichengreen (1994), and Obstfeld and Rogoff (1995). The latter study notes that in 1995, following the collapse of the British pound in September 1992 and of the Mexican peso in December 1994, that "Many recent efforts to peg exchange rates within narrow ranges have ended in spectacular debacles." The authors went on to conclude "These events are not unprecedented but their ferocity and scope have called into question the viability of fixed rates among sovereign nations in today's world of highly developed global capital markets." The subsequent fall of tightly managed regimes in East Asia (1997), Russia (1998), Brazil (1999), and Argentina (2002) have served as a continuing warning against pegged regimes, especially in emerging markets subject to volatile capital flows. Pegged exchange rates-or those with limited flexibility-invite speculative activity against the exchange rate and lead to abandonment of the peg, currency overshooting, and large output costs (Larraín and Velasco, 2001). Pegged regimes may also be subject to a higher incidence of banking crises.
Under pegs, the exchange rate may become progressively overvalued, weakening the financial system; without, or with only limited, lender-of-last-resort capabilities, authorities may be unable to deal with domestic financial distress.

Table 3.1 summarizes these predictions for economic performance across regimes.

\section{Macroeconomic Performance and Crisis Probabilities: Summary Statistics}

Drawing on both the de facto and de jure classifications, the following portion describes the association between exchange rate regimes and various dimensions of economic performance. No attempt is made in this preliminary description to control for other factors that may also influence economic outcomes. First, a summary of average macroeconomic performance under alternate regimes is presented. Second, because the occurrence of crises has been particularly highlighted in recent policy discussions, the relationship between regimes and the frequency of banking and currency crises is documented.

\section{Regimes and Performance: Summary Measures for Inflation, Growth, and Volatility}

Conflicting policy objectives and large macroeconomic imbalances will lead to poor economic performance irrespective of the exchange rate regime. For the purposes of this discussion, there are at least two sets of conditions under which the exchange rate regimes may have no independent influence on macroeconomic outcomes through the prevailing 
Table 3.2. Average Annual Inflation and Real Per Capita GDP Growth: Comparison of Dual (or Multiple) and Unified Exchange Rate Systems, |970-99|

(In percent)

\begin{tabular}{lcc}
\hline Average Annual & $\begin{array}{c}\text { Anflation Rate } \\
\text { Unified exchange rate }\end{array}$ & $\begin{array}{c}\text { Average Per Capita } \\
\text { GDP Growth }\end{array}$ \\
Dual (or multiple) exchange rates & 22.0 & 1.8 \\
$(7.7)$ & 175.6 & 0.6 \\
$(15.1)$ & $(1.4)$ \\
\hline
\end{tabular}

Source: Author's calculations.

'Figures in parentheses are medians.

severity of economic distortions. First, the prevalence of dual (or multiple) rates-and, hence, a potentially large differential in official and parallel market exchange rates-is a consideration in determining the operative regime as well as a factor influencing economic outcomes through the prevailing severity of economic distortions, as observed in Reinhart and Rogoff (2004). Second, the authors isolate countries with annual inflation rates above 40 percent into a separate freely falling category, with the implication that the macroeconomic imbalances in such conditions overwhelm the possible effects of the exchange rate regime.

The evidence suggests that dual exchange rates are associated with significantly worse economic performance. Over the period 1970-99, the average per capita income growth rate in countries with dual exchange rates was about 0.6 percent per year; in contrast, countries with unified rates grew at three times the pace, at about 1.8 percent per year (Table 3.2). Similarly, annual inflation in countries with dual exchange rates was about 175 percent, while under unified rates it was about 22 percent. These performance differences primarily reflect instances of large departures from official rates-the differences in median performance are less egregious. With increasingly integrated capital markets, large gaps between official and parallel rates have become untenable, and the move to unified exchange rates has been almost universal (see Section II).

By their construction, freely falling regimes perform significantly worse than other regimes on all counts: they have higher inflation, lower growth rates, and higher volatility (Tables 3.3, 3.4, and 3.5). With the worldwide decline in inflation, the incidence of freely falling regimes is on the decline (Rogoff, 2003). For retrospective analyses, however, because freely falling episodes are typically classified under other systems as freely floating, their identification as a separate category in the Natural classification can make a significant difference to the relative rankings of regimes. For example, according to the de jure classification (the last column in Table 3.3 ), pegs have a much lower inflation rate than floating regimes. Under the Natural classification, however, freely floating regimes (the bottom row of Table 3.3) have, on average, lower inflation than exchange rate pegs. This reversal occurs because, as noted, many freely falling episodes are in the floating regime category according to the de jure classification. As noted below, when other influences on inflation are taken into account, the advantage of pegged and intermediate regimes over the floating regime reappears even in the Natural classification; however, not distinguishing the freely falling category renders that advantage much larger.

The performance of intermediate regimes is not especially different from that of other regimes (Tables 3.3, 3.4, and 3.5). This is consistent with the longevity of these regimes, as documented in Section II. If this comparison had revealed consistently poorer performance under intermediate regimes, there would have been a greater basis for expecting a shift to the polar extremes of pegs and free floats.

Finally, as documented by Mussa (1986), Baxter and Stockman (1989), and Flood and Rose (1995), real exchange rates are more variable the greater the flexibility of the regime (Table 3.6). Exchange rate volatility is considerably higher under managed floating and freely floating regimes than under pegged and limited flexibility regimes. This reflects the fact that real rates tend, at least in the short run, to move closely with nominal rates. Notably, more flexibility under the de jure classification is not associated with greater variability of the real exchange rate because regimes that are declared flexible are often tightly managed. 


\begin{tabular}{|c|c|c|c|c|c|c|c|}
\hline & Peg & $\begin{array}{l}\text { Limited } \\
\text { Flexibility }\end{array}$ & $\begin{array}{c}\text { Managed } \\
\text { Floating }\end{array}$ & $\begin{array}{l}\text { Freely } \\
\text { Floating }\end{array}$ & $\begin{array}{l}\text { Freely } \\
\text { Falling }\end{array}$ & Unknown & Total \\
\hline Pegged & $\begin{array}{l}17.9 \\
(6.8)\end{array}$ & $\begin{array}{c}9.6 \\
(7.9)\end{array}$ & $\begin{array}{c}14.2 \\
(10.4)\end{array}$ & $\begin{array}{c}24.5 \\
(23.2)\end{array}$ & $\begin{array}{l}391.7 \\
(39.9)\end{array}$ & $\begin{array}{l}12.4 \\
(6.5)\end{array}$ & $\begin{array}{c}33.9 \\
(7.9)\end{array}$ \\
\hline Intermediate & $\begin{array}{l}11.2 \\
(3.5)\end{array}$ & $\begin{array}{l}13.0 \\
(9.1)\end{array}$ & $\begin{array}{c}16.7 \\
(15.1)\end{array}$ & $\begin{array}{c}9.2 \\
(3.8)\end{array}$ & $\begin{array}{l}147.6 \\
(66.1)\end{array}$ & $\begin{array}{c}25.7 \\
(15.9)\end{array}$ & $\begin{array}{c}36.0 \\
(10.8)\end{array}$ \\
\hline Floating & $\begin{array}{c}20.3 \\
(I 1.5)\end{array}$ & $\begin{array}{l}10.1 \\
(7.5)\end{array}$ & $\begin{array}{l}11.3 \\
(8.4)\end{array}$ & $\begin{array}{c}8.1 \\
(4.5)\end{array}$ & $\begin{array}{l}408.9 \\
(68.6)\end{array}$ & $\begin{array}{c}445.6 \\
(22.2)\end{array}$ & $\begin{array}{c}138.5 \\
(10.8)\end{array}$ \\
\hline Total & $\begin{array}{l}17.1 \\
(6.5)\end{array}$ & $\begin{array}{l}11.1 \\
(8.3)\end{array}$ & $\begin{array}{c}14.2 \\
(10.8)\end{array}$ & $\begin{array}{c}9.9 \\
(4.8)\end{array}$ & $\begin{array}{c}305.3 \\
(57.0)\end{array}$ & $\begin{array}{l}55.5 \\
(7.6)\end{array}$ & $\begin{array}{l}49.7 \\
(8.7)\end{array}$ \\
\hline
\end{tabular}

Source: Author's calculations.

'Figures in parentheses are medians.

\section{Regimes and Crisis Probabilities}

In the 1990s, several economies with rigid exchange rate regimes were victims of severe economic crises. A concern thus arose not just for the prospects of the economies directly subject to the crises but also for the possible contagion of crises across countries with similar economic features following a general loss of investor confidence. The occurrence of crises has, therefore, acquired greater prominence in the policy discussions on the choice of exchange rate regimes. Despite the policy interest, few systematic studies have examined the links between crises and exchange rate regimes.

The evidence presented in this section suggests that popular perception in this regard has some statistical basis. While the evidence on currency crises is mixed, the frequency of banking and twin crises, where banking and currency turbulence come together, has been higher under more rigid regimes but mainly for emerging markets, and particularly so in the 1990s. As noted in the introduction, emerging markets are more exposed to international capital flows than are other developing economies, but compared to advanced industrialized economies emerging markets have fragile financial sectors. ${ }^{41}$

\footnotetext{
${ }^{41}$ Emerging markets are defined here as those countries classified as such by Morgan Stanley Capital International on the basis of several factors but including also their access to international capital markets. As discussed in the appendix, any definition of emerging markets is likely to include or exclude countries on the margin in ways that are more or less appropriate. Extensive robustness tests were undertaken, and only the most robust results are highlighted in the text.
}

Consider, first, the frequency of banking crises. ${ }^{42}$ More rigid regimes had a higher likelihood of banking crises, especially in the 1990s. For all countries, during the period $1980-97$, the probability of a banking crisis in a given year varied between about 3 and 4.5 percent, with no clear variation across exchange rate regimes (Table 3.7). ${ }^{43}$ The highest probabilities of a banking crisis occurred in the emerging market economies, however, where the evidence also suggests that the probability of a crisis increased with the rigidity of the exchange rate regime. Moreover, the association between rigidity and probability of banking crises in emerging markets became stronger in the 1990s.

The finding that banking crises are more likely to occur under rigid regimes is in contrast to that of Ghosh, Gulde, and Wolf (2003), who conclude that, if anything, floating regimes are the most likely to experience banking crises. The difference in findings is the consequence of the latter's use of the de jure

\footnotetext{
${ }^{42} \mathrm{Crisis}$ probabilities were obtained as the ratio of crises episodes under a particular regime divided by the number of regime years. Each crisis was treated as a single episode even if it lasted for multiple years. The estimates presented drop the year of the crisis itself as well as the years immediately preceding and following the regime change to minimize the influence of the regime transition on the occurrence of crises.

${ }^{43}$ The data for banking crises are obtained from DemirgüçKunt and Detragiache (1998), who declare a banking crisis to have occurred when any one of the following four conditions held: nonperforming loans exceeded 10 percent of banking system assets; a bailout cost 2 percent or more of GDP; large-scale nationalization occurred; or other emergency measures, such as bank holidays, deposit freezes, and special guarantees had to be undertaken.
} 
Table 3.4. Average Annual Real Per Capita GDP Growth Across Exchange Rate Regimes, 1970-991 (In percent)

\begin{tabular}{|c|c|c|c|c|c|c|c|}
\hline & Peg & $\begin{array}{l}\text { Limited } \\
\text { Flexibility }\end{array}$ & $\begin{array}{l}\text { Managed } \\
\text { Floating }\end{array}$ & $\begin{array}{l}\text { Freely } \\
\text { Floating }\end{array}$ & $\begin{array}{l}\text { Freely } \\
\text { Falling }\end{array}$ & Unknown & Total \\
\hline Pegged & $\begin{array}{l}2.0 \\
(2.0)\end{array}$ & $\begin{array}{c}2.6 \\
(2.6)\end{array}$ & $\begin{array}{c}1.6 \\
(1.6)\end{array}$ & $\begin{array}{c}-3.2 \\
(0.5)\end{array}$ & $\begin{array}{l}-1.1 \\
(-0.7)\end{array}$ & $\begin{array}{l}1.0 \\
(0.6)\end{array}$ & $\begin{array}{c}1.6 \\
(1.6)\end{array}$ \\
\hline Intermediate & $\begin{array}{c}2.8 \\
(2.4)\end{array}$ & $\begin{array}{c}2.6 \\
(2.9)\end{array}$ & $\begin{array}{c}1.9 \\
(2.1)\end{array}$ & $\begin{array}{c}2.7 \\
(2.2)\end{array}$ & $\begin{array}{l}0.0 \\
(0.4)\end{array}$ & $\begin{array}{l}2.7 \\
(2.7)\end{array}$ & $\begin{array}{c}2.1 \\
(2.3)\end{array}$ \\
\hline Floating & $\begin{array}{c}3.6 \\
(2.9)\end{array}$ & $\begin{array}{c}1.7 \\
(1.8)\end{array}$ & $\begin{array}{c}1.6 \\
(2.2)\end{array}$ & $\begin{array}{c}2.2 \\
(2.3)\end{array}$ & $\begin{array}{l}-3.1 \\
(-1.2)\end{array}$ & $\begin{array}{l}-1.6 \\
(-0.3)\end{array}$ & $\begin{array}{c}0.6 \\
(1.7)\end{array}$ \\
\hline Total & $\begin{array}{c}2.1 \\
(2.2)\end{array}$ & $\begin{array}{c}2.4 \\
(2.6)\end{array}$ & $\begin{array}{c}1.7 \\
(2.0)\end{array}$ & $\begin{array}{c}1.8 \\
(2.0)\end{array}$ & $\begin{array}{c}-1.3 \\
(-0.6)\end{array}$ & $\begin{array}{c}0.8 \\
(0.6)\end{array}$ & $\begin{array}{c}1.5 \\
(1.8)\end{array}$ \\
\hline
\end{tabular}

Source: Author's calculations.

'Figures in parentheses are medians.

Table 3.5. Average Annual Growth Volatility Across Exchange Rate Regimes, 1970-991 (In percent)

\begin{tabular}{|c|c|c|c|c|c|c|c|}
\hline & Peg & $\begin{array}{l}\text { Limited } \\
\text { Flexibility }\end{array}$ & $\begin{array}{l}\text { Managed } \\
\text { Floating }\end{array}$ & $\begin{array}{l}\text { Freely } \\
\text { Floating }\end{array}$ & $\begin{array}{l}\text { Freely } \\
\text { Falling }\end{array}$ & Unknown & Total \\
\hline Pegged & $\begin{array}{c}4.0 \\
(2.7)\end{array}$ & $\begin{array}{c}3.8 \\
(2.3)\end{array}$ & $\begin{array}{c}3.6 \\
(2.6)\end{array}$ & $\begin{array}{c}5.7 \\
(3.3)\end{array}$ & $\begin{array}{c}4.3 \\
(3.4)\end{array}$ & $\begin{array}{c}4.3 \\
(2.9)\end{array}$ & $\begin{array}{c}4.0 \\
(2.7)\end{array}$ \\
\hline Intermediate & $\begin{array}{c}1.6 \\
(1.2)\end{array}$ & $\begin{array}{c}2.0 \\
(1.6)\end{array}$ & $\begin{array}{c}2.6 \\
(1.8)\end{array}$ & $\begin{array}{c}3.3 \\
(1.7)\end{array}$ & $\begin{array}{c}3.8 \\
(3.4)\end{array}$ & $\begin{array}{l}6.1 \\
(2.5)\end{array}$ & $\begin{array}{c}2.6 \\
(1.8)\end{array}$ \\
\hline Floating & $\begin{array}{l}3.1 \\
(1.8)\end{array}$ & $\begin{array}{c}2.4 \\
(1.5)\end{array}$ & $\begin{array}{c}4.1 \\
(1.9)\end{array}$ & $\begin{array}{l}1.9 \\
(1.1)\end{array}$ & $\begin{array}{c}6.4 \\
(4.6)\end{array}$ & $\begin{array}{c}4.9 \\
(2.9)\end{array}$ & $\begin{array}{c}3.8 \\
(1.9)\end{array}$ \\
\hline Total & $\begin{array}{c}3.7 \\
(2.4)\end{array}$ & $\begin{array}{c}2.8 \\
(1.8)\end{array}$ & $\begin{array}{c}3.5 \\
(2.3)\end{array}$ & $\begin{array}{l}2.7 \\
(1.3)\end{array}$ & $\begin{array}{c}4.7 \\
(3.7)\end{array}$ & $\begin{array}{c}4.5 \\
(2.9)\end{array}$ & $\begin{array}{c}3.7 \\
(2.4)\end{array}$ \\
\hline
\end{tabular}

Source: Author's calculations.

'Figures in parentheses are medians.

classification, which has many more countries classified as floating than does the Natural classification. As noted in Section II, many of these de jure floaters are classified under the Natural classification as freely falling; other floaters did not actually float and so were de facto under more rigid regime categories. As a consequence, using the de jure classification leads to an overstatement of the likelihood of banking crises under floating regimes and an understatement of crisis probabilities under more rigid regimes.

Currency crises over the years 1970 to 2000 tended to occur more frequently in intermediate regimes, based on a measure of currency crises employed by Berg, Borensztein, and Pattillo (2004). ${ }^{44}$ The evidence for the 1990s is less clear cut and suggests that, among emerging markets, pegged regimes had more frequent currency crises. An alternative measure of currency crises, using different thresholds for exchange rate depreciation and loss in reserves (Bordo

\footnotetext{
${ }^{44}$ Berg, Borensztein, and Pattillo (2004) recognize a crisis as having occurred when the weighted average of one-month changes in the exchange rate and reserves is more than three (country-specific) standard deviations above the country average.
} 
Table 3.6. Real Exchange Rate Volatility Across Exchange Rate Regimes, 1970-2002'

\begin{tabular}{lccccccc}
\hline & Peg & $\begin{array}{c}\text { Limited } \\
\text { Flexibility }\end{array}$ & $\begin{array}{c}\text { Managed } \\
\text { Floating }\end{array}$ & $\begin{array}{c}\text { Freely } \\
\text { Floating }\end{array}$ & $\begin{array}{c}\text { Freely } \\
\text { Falling }\end{array}$ & Unknown & Total \\
\hline Pegged & 6.3 & 8.9 & 25.1 & 7.0 & 53.6 & 6.6 & 12.7 \\
Intermediate & 3.2 & 4.8 & 10.5 & 30.6 & 42.3 & 28.4 & 12.1 \\
Floating & 10.5 & 5.2 & 11.6 & 8.4 & 17.3 & 14.8 & 10.4 \\
Total & 5.6 & 6.1 & 17.9 & 13.7 & 37.0 & 9.2 & 12.0
\end{tabular}

Source: Author's calculations.

IVolatility is measured as the three-year centered standard deviation of the annual real effective exchange rate (IFS, line RECZF). Nicaragua is excluded from this table because its exchange rate has been extremely volatile, and its inclusion unduly influences the averages.

and others, 2001), shows that pegs and limited flexibility had a significantly higher risk of currency crisis than managed or freely floating regimes ${ }^{45}$ for emerging markets.

Finally, twin crises have been almost uniquely an emerging market phenomenon: they have never occurred in the group of countries classified as developing and rarely in advanced economies. Moreover, the incidence of twin crises in emerging markets is highest under pegged regimes and falls as flexibility in regimes increases. Kaminsky and Reinhart (1999) have noted that twin crises have particularly high costs. Such crises typically start with domestic financial distress, which accelerates when a currency crisis also sets in, leading to a vicious cycle. Costs are high in terms of bailout of the financial sector as well as in terms of reserves lost. Larraín and Velasco (2001) provide a theoretical discussion of why currency boards may be particularly prone to twin crises. Rigid regimes may promote excessive risk taking during periods of booms in capital inflows, when the expectation of an exchange rate guarantee reduces the incentive to hedge foreign currency exposure. The sudden withdrawal of flows leaves the domestic financial sector susceptible to severe distress. At the same time, the commitment to an exchange rate target limits lender-of-last-resort operations. If depositors withdraw domestic currency from domestic banks to buy the foreign reserve currency at the central bank under a fixed exchange rate, the panic withdrawal can lead to a self-fulfilling crisis as foreign currency reserves are depleted. Argentina's massive collapse is a cautionary tale of how some of these forces can contribute to the unraveling of even a hard peg.

\footnotetext{
${ }^{45}$ Bubula and Ötker-Robe (2003) continue to find vulnerability in the intermediate regimes in the 1990s but does not distinguish emerging markets.
}

\section{Regime Performance and Levels of Development}

While the previous section reported correlations, this section takes the more demanding step of attempting to isolate, over the period 1970-99, the association between exchange rate regimes and the performance measures of interest, after controlling for other variables that may also influence performance. ${ }^{46}$ But even after such controls are included, reverse causality, or endogeneity, remains a concern in such analyses: in other words, the observed relationships may reflect the influence of the performance variable on the choice of the regime rather than the other way around. This problem cannot be fully resolved, but it is mitigated by the relatively long duration of the typical regime under the Natural classification, implying that temporary changes in performance do not influence the choice of regime. The problem is also mitigated by using as an explanatory variable the regime prevailing in the previous one or two years where the results presented are unchanged when that is done, except, as

\footnotetext{
${ }^{46}$ See the appendix for a detailed discussion of the methodology. In addition to variables that are used conventionally to explain the different dimensions of performance (discussed below), two further sets of controls are used throughout. First, common shocks across countries, such as spikes in oil prices or changes in the volatility of G-3 currencies, influence all economies beyond the effect channeled through observed variables. These are controlled for through the use of time dummies. Second, while an increasing number of country control variables can be added, certain unobserved or difficult-to-measure country characteristics may reflect important dimensions of institutions and policy credibility. These, in turn, are likely to be correlated with exchange rate regimes; to control for these unobserved characteristics, country dummies are included. The implication of this approach is that regime performance is judged by changes that occur within a country rather than across countries.
} 


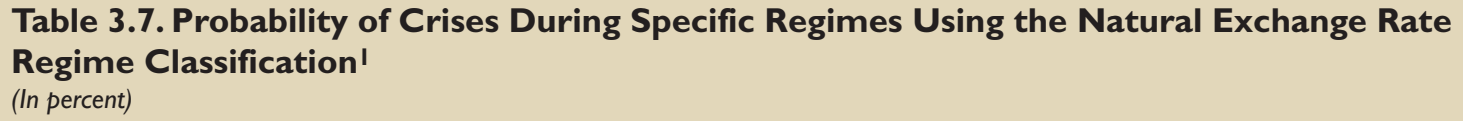

\begin{tabular}{|c|c|c|c|c|c|c|c|c|}
\hline & \multicolumn{4}{|c|}{ Bank Crisis (1980-97) } & \multicolumn{4}{|c|}{ Bank Crisis (1990-97) } \\
\hline & Peg & $\begin{array}{l}\text { Limited } \\
\text { Flexibility }\end{array}$ & $\begin{array}{l}\text { Managed } \\
\text { Floating }\end{array}$ & $\begin{array}{l}\text { Freely } \\
\text { Floating }\end{array}$ & Peg & $\begin{array}{l}\text { Limited } \\
\text { Flexibility }\end{array}$ & $\begin{array}{l}\text { Managed } \\
\text { Floating }\end{array}$ & $\begin{array}{l}\text { Freely } \\
\text { Floating }\end{array}$ \\
\hline All & 3.4 & 4.7 & 4.5 & 3.9 & 3.1 & 7.1 & 3.0 & 3.8 \\
\hline Advanced & 0.0 & 2.7 & 2.3 & 4.1 & 0.0 & 6.5 & 0.0 & 4.2 \\
\hline Emerging & 11.4 & 7.5 & 7.0 & 0.0 & 15.4 & 8.0 & 3.8 & 0.0 \\
\hline \multirow[t]{3}{*}{ Developing } & 2.8 & 7.0 & 3.6 & - & 2.6 & 7.1 & 4.5 & - \\
\hline & \multicolumn{4}{|c|}{ Balance of Payments Crisis (1970-2000) } & \multicolumn{4}{|c|}{ Balance of Payments Crisis (1990-2000) } \\
\hline & Peg & $\begin{array}{l}\text { Limited } \\
\text { Flexibility }\end{array}$ & $\begin{array}{l}\text { Managed } \\
\text { Floating }\end{array}$ & $\begin{array}{l}\text { Freely } \\
\text { Floating }\end{array}$ & Peg & $\begin{array}{l}\text { Limited } \\
\text { Flexibility }\end{array}$ & $\begin{array}{l}\text { Managed } \\
\text { Floating }\end{array}$ & $\begin{array}{l}\text { Freely } \\
\text { Floating }\end{array}$ \\
\hline All & 4.1 & 4.1 & 9.2 & 4.6 & 4.7 & 5.2 & 9.2 & 4.3 \\
\hline Advanced & 3.3 & 3.9 & 7.1 & 4.9 & 3.6 & 5.8 & 8.6 & 4.9 \\
\hline Emerging & 4.6 & 5.6 & 10.0 & 0.0 & 8.8 & 6.1 & 6.9 & 0.0 \\
\hline \multirow[t]{3}{*}{ Developing } & 5.2 & 2.0 & 9.7 & - & 0.0 & 2.8 & 15.4 & - \\
\hline & \multicolumn{4}{|c|}{ Twin Crises (1980-97) } & \multicolumn{4}{|c|}{ Twin Crises (1990-97) } \\
\hline & Peg & $\begin{array}{l}\text { Limited } \\
\text { Flexibility }\end{array}$ & $\begin{array}{l}\text { Managed } \\
\text { Floating }\end{array}$ & $\begin{array}{c}\text { Freely } \\
\text { Floating }\end{array}$ & Peg & $\begin{array}{l}\text { Limited } \\
\text { Flexibility }\end{array}$ & $\begin{array}{l}\text { Managed } \\
\text { Floating }\end{array}$ & $\begin{array}{l}\text { Freely } \\
\text { Floating }\end{array}$ \\
\hline All & 1.6 & 1.4 & 0.8 & 0.0 & 3.2 & 2.6 & 0.0 & 0.0 \\
\hline Advanced & 0.0 & 0.7 & 0.0 & 0.0 & 0.0 & 2.2 & 0.0 & 0.0 \\
\hline Emerging & 7.7 & 3.0 & 1.8 & 0.0 & 15.4 & 4.0 & 0.0 & 0.0 \\
\hline Developing & 0.0 & 0.0 & 0.0 & - & 0.0 & 0.0 & 0.0 & - \\
\hline
\end{tabular}

\footnotetext{
Source: Author's calculations.

IProbabilities are calculated by dividing the number of occurrences of a crisis under a particular regime by the total number of regime years. Each crisis is counted only once, and hence, if it persists over multiple years, the subsequent years are not taken into account for this calculation. Additionally, the years an exchange rate regime transition takes place (i.e., the year preceding, the year during, and the year following the transition) are excluded from this computation. A dash $(-)$ indicates that no crisis data were available for developing countries under freely floating exchange rate regimes.
}

discussed below, in the analysis of volatility in emerging markets. ${ }^{47}$

\section{Inflation Performance Across Exchange Rate Regimes}

A wide range of empirical studies have found that fixed exchange rate regimes deliver lower inflation. IMF (1997) found that the median inflation rates for fixed regimes have been lower than those for floating regimes, though the difference declined over time. More rigorous studies that control for other determinants of inflation-for example, Ghosh, Gulde, and Wolf (2003) and Edwards and Magendzo (2003a and

\footnotetext{
${ }^{47}$ Moreover, as summarized in Appendix II, it is difficult to identify country characteristics that consistently predict exchange rate regimes. Since regimes are strongly persistent, they are likely to be the best predictors of expected regimes.
}

2003b)_support this conclusion. It turns out, however, to be important to distinguish between different country types. On average, pegged and intermediate regimes have been associated with significantly lower inflation rates than floating regimes, but this reflects an inflation benefit that accrues primarily to developing economies and not to emerging markets or advanced economies. ${ }^{48}$

Before examining the differentiation across country groups, it is useful to note that the findings with

\footnotetext{
${ }^{48}$ This finding is consistent with, but goes beyond, that obtained by Ghosh, Gulde, and Wolf (2003), who, using the de jure classification, find little difference in inflation performance across regimes in upper-income (advanced) countries but do find greater rigidity to be associated with lower inflation in middle- and lower-income countries. Distinguishing further between emerging markets and developing economies shows the latter to be the primary beneficiaries of exchange rate rigidity.
} 


\section{Figure 3. I. Inflation Performance Across Regimes: Confidence Effect I \\ (In percent)}
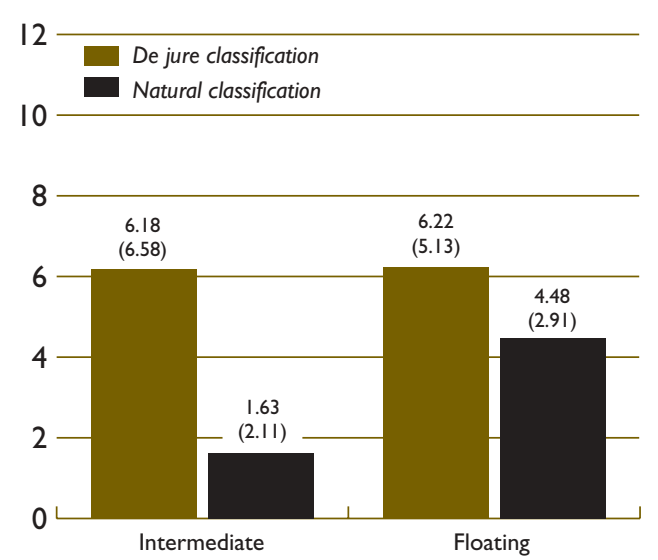

Source: Authors' calculations.

IFigures in parentheses are t-statistics. The bars depict differences in performance relative to pegged exchange rate regimes, conditioning on a range of other variables. See appendix in Section III for details.

\section{Figure 3.2. Inflation Performance Across Regimes: Confidence and Discipline Effects 1 (In percent)}

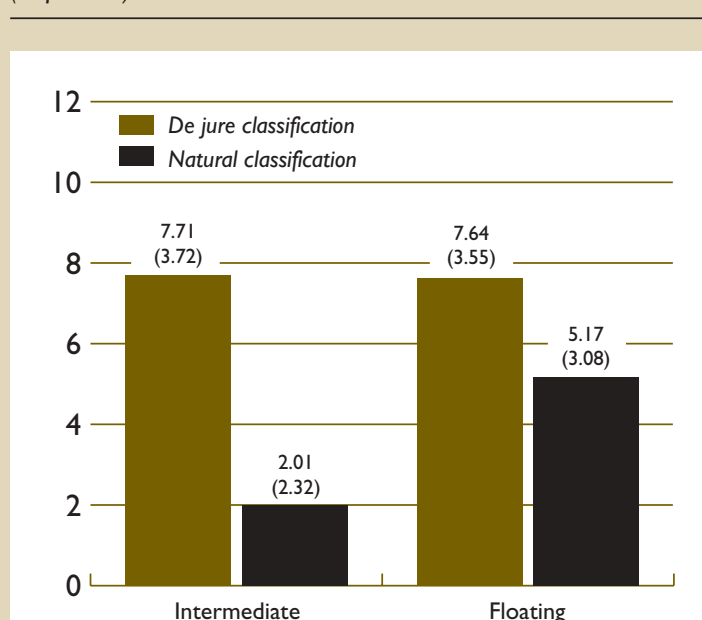

Source: Authors' calculations.

IFigures in parentheses are t-statistics. The bars depict differences in performance relative to pegged exchange rate regimes, conditioning on a range of other variables. See appendix in Section III for details. respect to inflation performance across all countries are similar whether the de jure or the Natural classification is used. Figure 3.1, which pools all countries, contrasts the results using the de jure classification with those for the Natural classification. The bars in the figure represent the difference in inflation in intermediate and floating rate regimes relative to pegged regimes, after controlling for a variety of factors thought to influence inflation in all regimes. ${ }^{49} \mathrm{Be}-$ cause the regressions control for money growth, they can be thought of as capturing the value of credibility rather than greater discipline, whereby pegs generate lower inflation through control on the growth of money supply, for example. Using the de jure classification, floating regimes are associated with significantly higher inflation than pegged regimes, on average 6.2 percent.

For the Natural classification, pegged regimes continue to exhibit significantly lower inflation than freely floating regimes, though the margin by which they do so (4.5 percent) is smaller. In addition, intermediate regimes now perform significantly better (by 2.9 percent) than floating regimes in terms of inflation. Separating out the freely falling category reduces the average inflation rate for freely floating regimes, thereby reducing the inflation advantage of pegged regimes and giving some inflation advantage to intermediate regimes.

The effect on inflation through potentially greater monetary discipline under restrictive regimes is significantly smaller than that due to enhanced credibility. Figure 3.2 captures the discipline effect by attributing differences in rates of money supply growth to the regimes themselves and thus imputing additional discipline effects based on these differences. Using the de jure classification, the discipline effect adds to the inflation advantage of pegged regimes somewhat. The same holds for the Natural

\footnotetext{
${ }^{49}$ The results presented in graphical form are the coefficients on dummy, or categorical, variables representing the exchange rate regime. These coefficients should be interpreted as a regime's performance (relative to the excluded pegged regime), conditional upon the other included variables in the regression. The two intermediate regimes in the coarse Natural classification have been aggregated to one regime for consistency with the de jure classification. Throughout, when using the Natural classification, the freely falling countries are also identified as an additional category. In line with the discussion on performance and crisis probabilities above, freely falling regimes do not perform as well as other regimes in most instances. Because their performance does not have a direct implication for policy discussion on exchange rate regime performance, however, the results are not presented in the main text but are included in the tables in the appendix, which discusses these issues in further detail. All the inflation regressions control for real GDP and money growth, in addition to trade openness, the degree of central bank independence, terms-of-trade shocks, and the fiscal balance. In addition, as noted above, each regression has country-specific fixed effects and year dummies.
} 


\section{Figure 3.3. Inflation Performance in Advanced Countries, Emerging Markets, and Developing Countries: Confidence Effect'I \\ (In percent)}

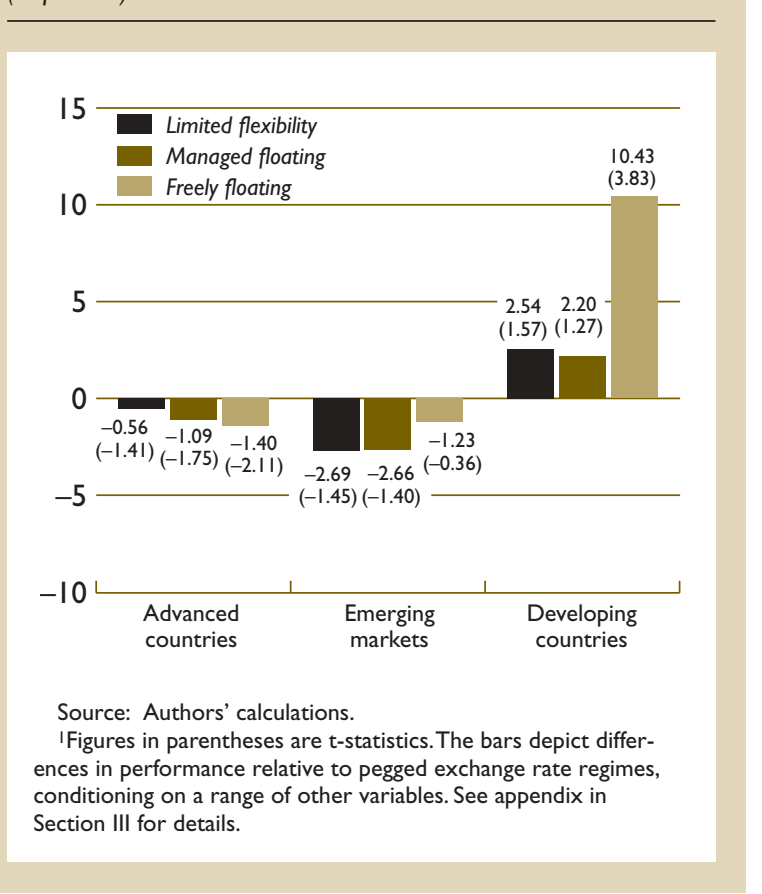

classification, where the inflation advantage attributed to exchange rate pegs and to intermediate regimes relative to floating rises modestly. But overall these effects are small.

A different story emerges when inflation performance is distinguished across the advanced countries group, emerging markets, and developing countries (Figures 3.3 and 3.4). In developing countries, inflation performance deteriorates with exchange rate flexibility. The results indicate that pegged regimes have the lowest inflation, about 2.5 percent per annum lower than countries with intermediate flexibility; floating regimes experience inflation that is about 8 percent a year more than regimes with intermediate flexibility. Note that, though the difference between pegs and intermediate regimes is not statistically significant, the difference between pegs and floating regimes is highly significant. This result holds up consistently in a variety of empirical specifications (see, for example, Table A3.4 in the appendix).

In emerging markets, inflation performance shows no significant relationship with greater exchange rate flexibility. When, however, the regime prevailing in the prior one or two years is used as the explanatory variable (to minimize the influence of the relatively

\section{Figure 3.4. Inflation Performance in Advanced Countries, Emerging Markets, and Developing Countries: Confidence and Discipline Effects! \\ (In percent)}

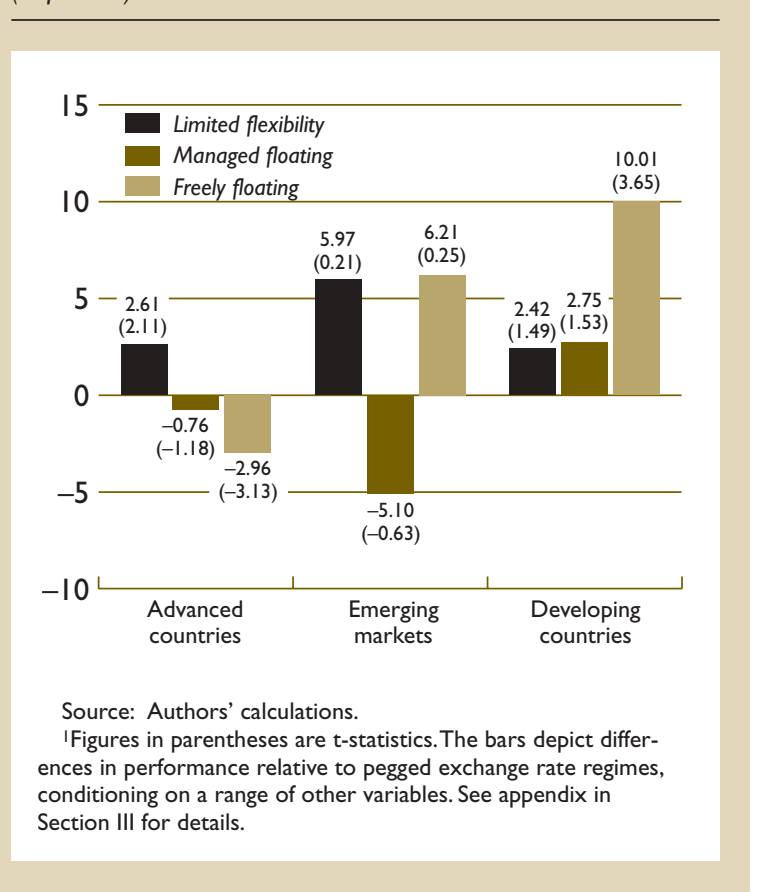

high rate of regime transitions in this group of countries), there is some evidence that, as in developing economies, inflation rises with flexibility. This may explain the fear of floating ${ }^{50}$ because the reduction in pass-through to domestic prices may take time. For advanced countries, there is evidence that inflation actually declines with increased exchange rate flexibility. While the direction of the results typically favors floating over pegged, the results in alternate specifications are not always so clear, and the appropriate conclusion appears to be that floating regimes do no worse than pegged regimes in terms of inflation performance in advanced economies. These differences across advanced countries, emerging markets, and developing countries are similarly apparent in Figure 3.4, which incorporates the abovementioned discipline effects via monetary policy.

Overall, these results suggest that there may be some merit to pegged and intermediate regimes in developing countries perhaps reflecting the fact that, in the absence of sound institutions and a strong

\footnotetext{
${ }^{50}$ See Tables A3.4 and A3.7 in the appendix. Also, hard pegs may have better inflation performance in emerging markets relative to other regimes; however, the effect is only marginally significant statistically.
} 


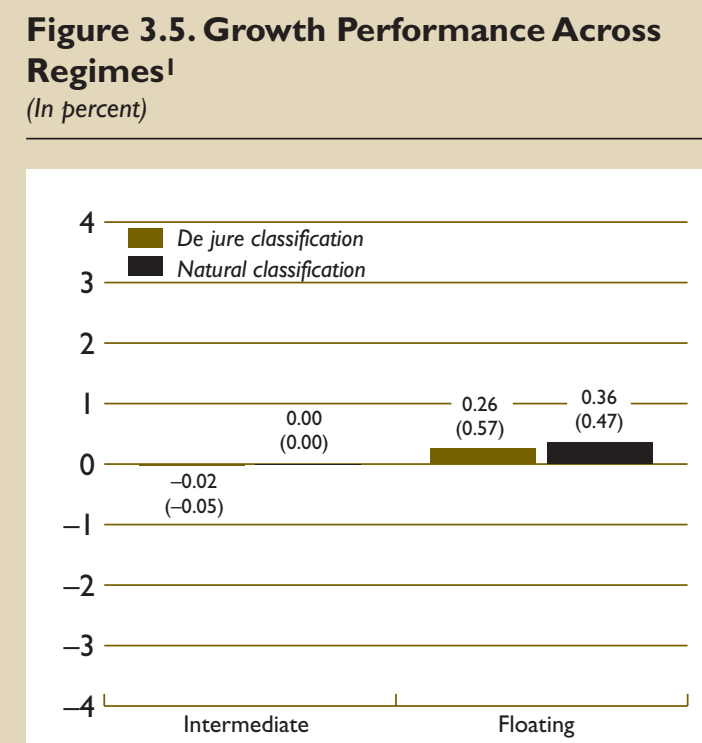

Source: Authors' calculations.

IFigures in parentheses are t-statistics. The bars depict differences in performance relative to pegged exchange rate regimes, conditioning on a range of other variables. See appendix in Section III for details.

\section{Figure 3.6. Growth Performance in Advanced Countries, Emerging Markets, and Developing Countries I \\ (In percent)}

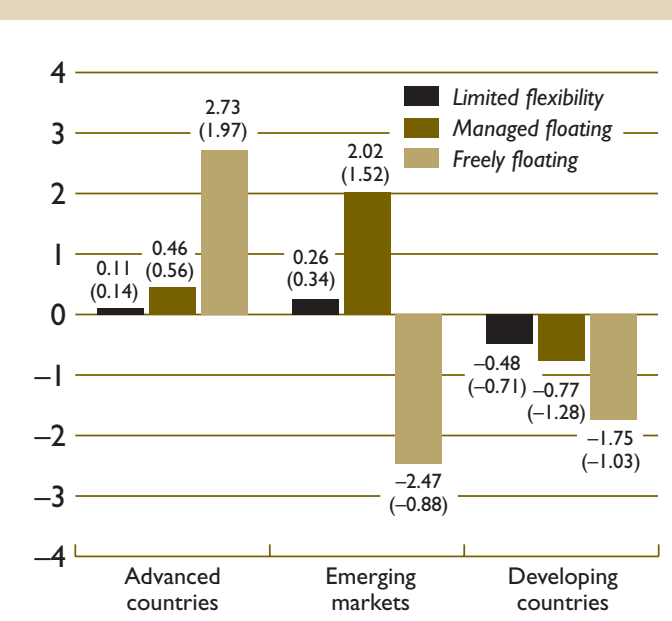

Source: Authors' calculations.

IFigures in parentheses are t-statistics. The bars depict differences in performance relative to pegged exchange rate regimes, conditioning on a range of other variables. See appendix in Section III for details. track record, these regimes can enhance policy credibility and discipline monetary policy. This does not, of course, imply a blanket recommendation of pegged regimes because many country-specific features would need to be taken into account in making that decision, including the appropriate level at which to peg the exchange rate. As countries gain access to international capital markets, there appears to be no evidence of inflation reduction through the adoption of rigid regimes.

\section{Per Capita Income Growth Across Exchange Rate Regimes}

Does the inflation advantage of pegged and intermediate over floating regimes in developing countries help growth (through reduced interest rates and lower uncertainty, as Dornbusch, 2001, suggests); does it come at the expense of growth; or does the exchange rate regime make no difference to growth (as Eichengreen, 2001, concludes)?

For the full sample of countries (Figure 3.5), both the de jure and de facto classifications show virtually no relationship between exchange rate flexibility and growth. ${ }^{51}$ For developing economies (Figure 3.6), growth appears to decline with increased flexibility, though the effect is not statistically significant. Thus, the association observed above of lower inflation with greater rigidity apparently does not come at the expense of growth; but neither does lower inflation have a measurable favorable effect through, for example, lower interest rates and reduced uncertainty. For emerging markets, the relationship between growth and regimes is noisy, as with inflation.

In contrast, for advanced countries free floats do significantly better than other regimes in terms of growth performance. Indeed, the results suggest that for advanced economies exchange rate rigidity is monotonically associated with slower growth, which is even more apparent when regimes are lagged, as reported in the appendix. Because in the advanced countries no inflation benefit is associated with greater rigidity-indeed, if anything, inflation per-

\footnotetext{
${ }^{51}$ The results are based on separate panel regressions of real per capita GDP growth on the relevant set of regime dummies, with the pegged regime as the omitted category. Again, the two intermediate categories in the Natural classification have been aggregated for better comparison with the de jure classification. Each regression follows Ghosh, Gulde, and Wolf (2003) in controlling for factor accumulation (investment ratio, education, and population level and growth); trade openness; terms-of-trade shocks; importance of the government sector (tax ratio and central government balance); and conditional convergence. Finally, each regression includes country-specific fixed effects and year dummies, as above.
} 
formance worsens with more regime rigidity-there appears to be an overall benefit from floating. 52

The beneficial influence of flexible regimes as countries become more advanced is consistent with the view that floating permits more rapid adjustment following shocks, and that with stronger institutions-in particular, deep financial sectors-advanced economies are not subject to the offsetting risks of floating. Bordo and Flandreau (2001), in line with Calvo and Reinhart (2002), note that where domestic financial markets are underdeveloped, borrowing in foreign currency creates significant risks of sharp changes in an enterprise's net worth when exchange rates are flexible. As borrowing in domestic currencies becomes a viable option, the costs of flexibility fall. ${ }^{53}$ Bordo (2003) makes the further argument that advanced economies have always been more successful in managing the trade-off between achieving credibility and retaining flexibility. The author suggests that even during the period of the classical gold standard when exchange rates were fixed, the margin permitted by gold points allowed temporary changes in exchange rates. Of importance is the observation that these exchange rate changes were expected to be temporary - to deal with shocks - and hence a reversion to the parity was expected. In contrast, where credibility is low, deviations can generate the expectation of further deviations.

\section{Growth Volatility Across Exchange Rate Regimes}

Finally, consider the relationship between exchange rate regimes and output growth volatility. ${ }^{54}$ When using the Natural classification, growth volatility does not appear to vary systematically across regimes and across all countries (Figure

\footnotetext{
${ }^{52}$ Again, this result parallels that obtained by Ghosh, Gulde, and Wolf, who find that free floats register significantly higher growth than pegged regimes in upper- and upper-middle income countries; the authors also find little evidence among lower- and lower-middle income countries of a link between regimes and growth performance.

${ }^{53}$ The idea that better institutions are a driving force behind the difference in the results across advanced and developing countries is further supported by the robustness tests reported in the appendix.

${ }^{54}$ Figure 3.7 is based on separate panel regressions of the threeyear centered standard deviation of real per capita GDP growth on the relevant set of regime dummies, with pegged regimes the omitted category. Again, the two intermediate categories in the Natural classification have been aggregated for better comparison with the de jure classification. Other controls are similar to the growth regressions above. They include factor accumulation (investment ratio, education and population growth); trade openness; terms-of-trade growth; and the size of government (tax ratio and central government balance). Each regression also includes country-specific fixed effects and year dummies.
}

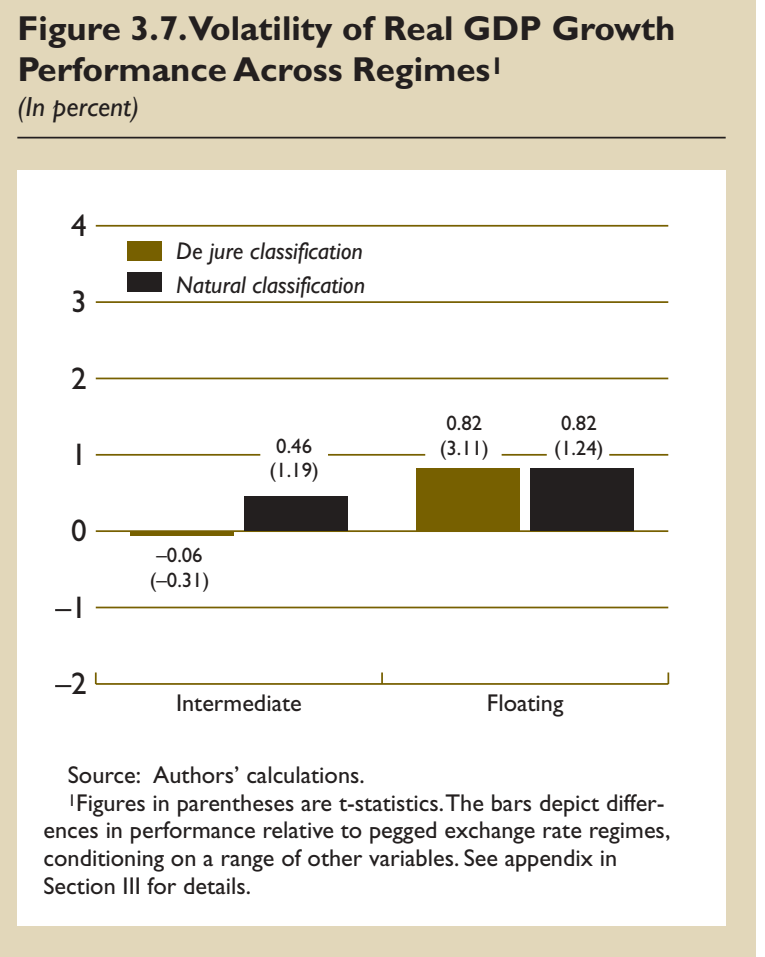

3.7). ${ }^{55}$ However, while there is essentially no relationship for developing countries, volatility appears to increase with flexibility in the other two groups of countries (Figure 3.8). The increase in volatility with flexibility in advanced economies comes at apparently little or no cost, as Rogoff (1999) suggests, and as implied by the earlier findings that flexibility is associated with higher growth and lower inflation.

For emerging markets, the story is more complex (Figure 3.8). Here there appears at first to be higher volatility associated with more flexibility. Two considerations, however, caution against that conclusion. First, the volatility associated with the collapse of rigid regimes is likely to register during subsequent regimes-an important consideration

\footnotetext{
${ }^{55}$ This is in contrast with the outcome under the de jure classification, where, relative to free floats, the standard deviation of real per capita GDP growth is significantly lower for pegged regimes ( 0.82 percent) and intermediate regimes ( 0.88 percent). The regressions for the de jure classification are very sensitive to the inclusion of country dummies. Without such fixed effects, growth volatility is greater under pegged than floating regimes, though not significantly so. With country dummies, the opposite is true. This explains the differences in results reported here from those of Ghosh, Gulde, and Wolf (2003) and, presumably, also of LevyYeyati and Sturzenegger (2003), since neither study includes country-specific fixed effects. For the Natural classification, there is little discernible pattern or significance with or without country dummies.
} 


\section{Figure 3.8. Volatility of Real GDP Growth Performance in Advanced Countries, Emerging Markets, and Developing Countries ${ }^{\prime}$ \\ (In percent)}

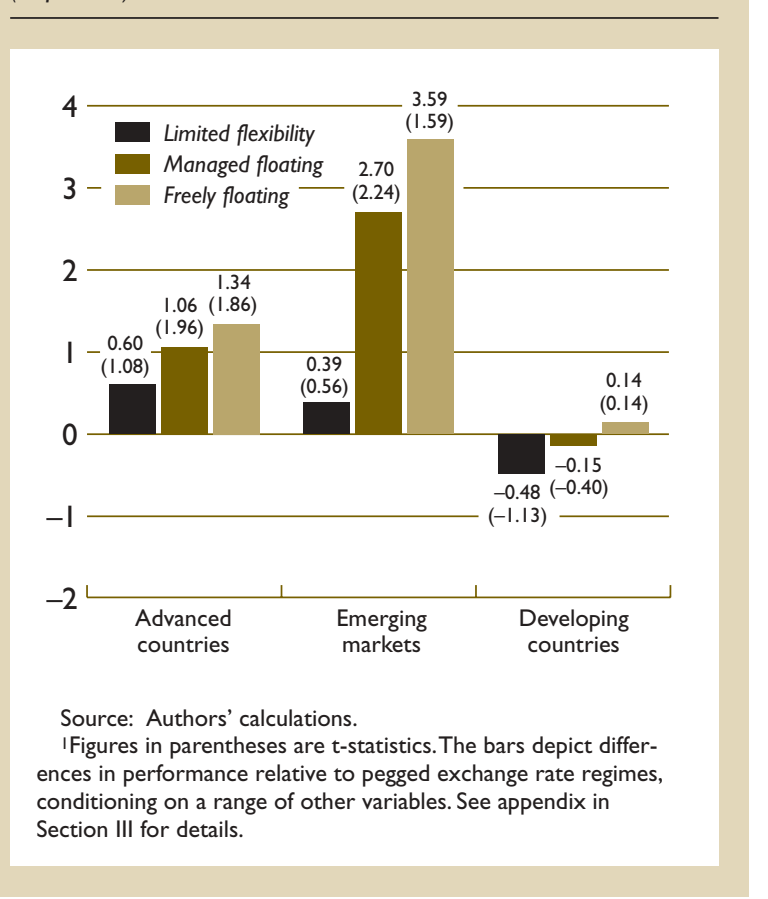

for emerging markets with their relatively high rate of transitions. Figure 3.9 investigates whether this phenomenon is quantitatively important. It compares the estimated volatility effects of regimes that prevailed in the previous one and two years (on the assumption that the spillover effects will be manifested mainly in the first two years of transition to a new regime). Now, the volatility in pegged regimes is actually higher relative to limited flexibility and freely floating, with little difference relative to managed floating. These results are not all statistically significant, but they point to significant spillover effects when transitions from pegged regimes occur. The implication is that the apparent relationship in emerging markets between flexibility and higher volatility is due largely to the volatility following the collapse of rigid regimes being attributed to subsequent more flexible regimes. Second, the transmission of volatility from rigid to flexible regimes appears more so the case for the 1990s, when the countries identified here as emerging markets began to tap international capital in a significant manner (Figure 3.10). Together with their higher likelihood of twin crises, as reported above, this appears to further strengthen the case against rigid regimes for emerging markets.
Figure 3.9. Volatility of Real GDP Growth and Contamination Across Regimes: Evidence from Emerging Markets 1 (In percent)

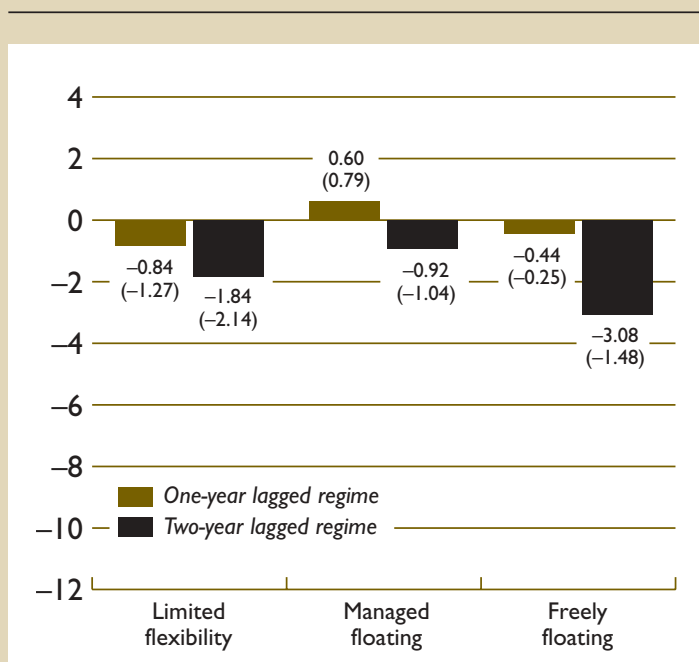

Source: Authors' calculations.

IFigures in parentheses are t-statistics. The bars depict differences in performance relative to pegged exchange rate regimes, conditioning on a range of other variables. See appendix in Section III for details.

Figure 3.I 0. Volatility of Real GDP Growth Across Regimes: Emerging Markets for the 1990s Only'

(In percent)

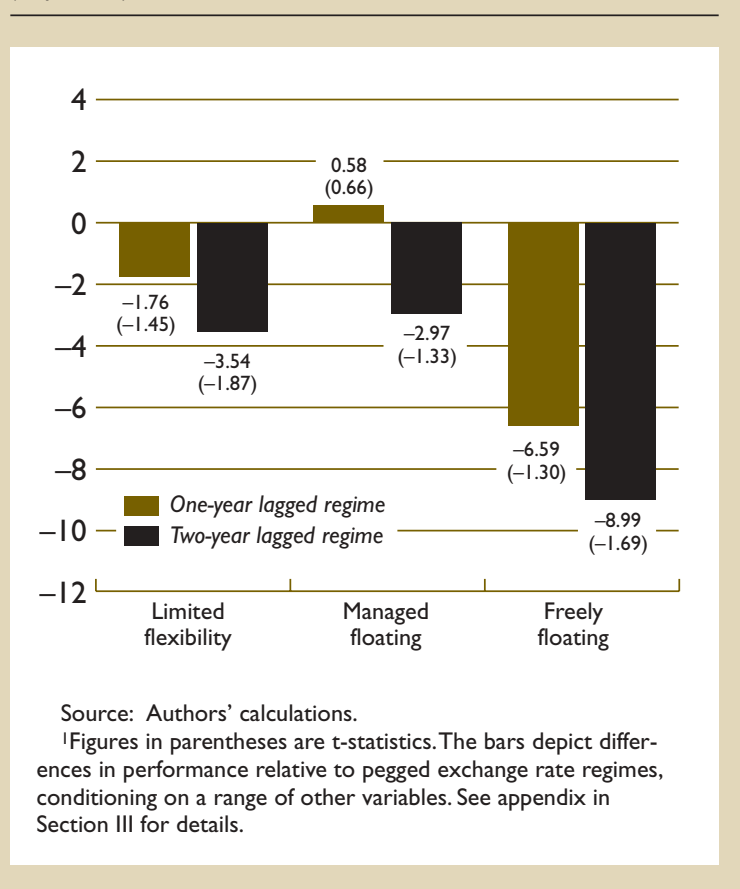




\section{Achieving Credibility in Developing and Emerging Economies}

The results given above suggest that for developing economies a benefit in the form of lower inflation has been associated with pegged and intermediate regimes and that such a benefit has not come at the expense of lower growth or higher volatility. Moreover, the inflation benefit of these relatively rigid regimes was found to accrue primarily through a credibility effect rather than through greater monetary discipline. Following is an investigation as to how developing countries can further enhance the credibility of their exchange rate regimes to improve macroeconomic performance. With respect to emerging markets, which do not seem to derive appreciable benefits from rigid regimes but also fear to float, the performance of floating regimes and whether they can be improved is examined below.

\section{Announcement Effects}

Is there an incremental inflation benefit associated with officially announcing an operative pegged regime? The presumption is that announcement implies a stronger commitment to maintaining the peg and hence to policies that are supportive of that regime. To consider the announcement effect, the overlap between de facto and de jure regimes was identified. The statistical task was to determine if the overlap added value to the regime.

Among developing countries, this announcement effect is large and significant for pegged regimes. As Figure 3.11 shows, once a separate announcement effect is allowed for, the small number of developing countries that pursued exchange rate pegs without explicitly announcing that policy exhibited average inflation that, if anything, was somewhat higher than that in other (especially intermediate) regimes. In other words, the inflation benefit of pegged regimes identified above did not derive merely from operating a tightly managed exchange rate. The big gain came only when the peg was official. In Figure 3.11 it is also interesting to note that the announcement of other regimes had the opposite effect of raising inflation. Thus the announcement benefit differentiated pegs from other regimes in an important way.

\section{Regime Duration}

Regimes that last longer presumably do so because macroeconomic policies are maintained in a consistent manner over time. If so, longer duration should add to a regime's credibility and be associated with superior performance. To proxy for the consistency of the macroeconomic stance with respect to the exchange rate regime, its duration (the number of years that a particular regime has been in force) was treated as an additional dimension of its characteristics.

The results imply that in developing countries pegged regimes delivered an inflation benefit even with no track record (i.e., with zero duration). In addition, the duration dimension for pegged regimes was highly significant and negative $(-0.2$ percent per year). Additionally, the calculations show that countries that maintained pegged regimes over a period of 10 years, for example, may have earned an additional inflation benefit of more than 80 percent over the initial inflation gain (see Figure 3.12).

Taken together, the lesson appears to be that developing countries that announce their peg and are able to maintain them over longer durations derive greater benefits from the rigidity in exchange rate regimes. While this finding is prima facie encouraging, it may be an insufficient policy guide in the context of the growing importance of international capital flows. Obstfeld and Rogoff (1995) note that most countries with long-lasting pegs adopted them in times when global capital markets were relatively shallow. Having achieved credibility during that

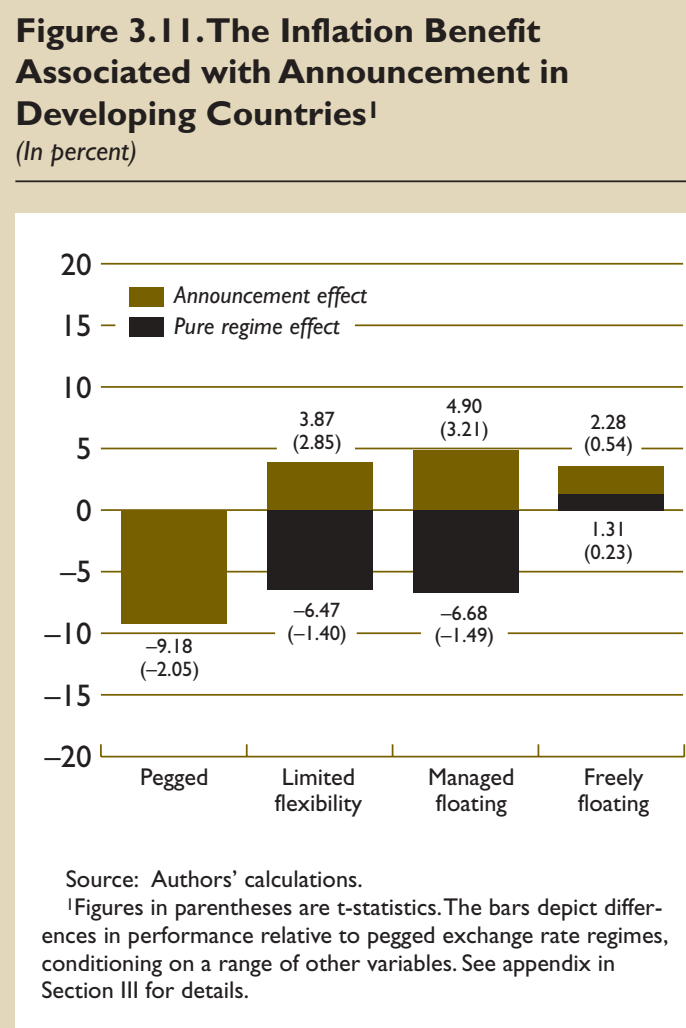




\section{Figure 3.I2.The Inflation Benefit Associated with Consistent Macroeconomic Policies in Developing Countries 1,2 \\ (In percent)}

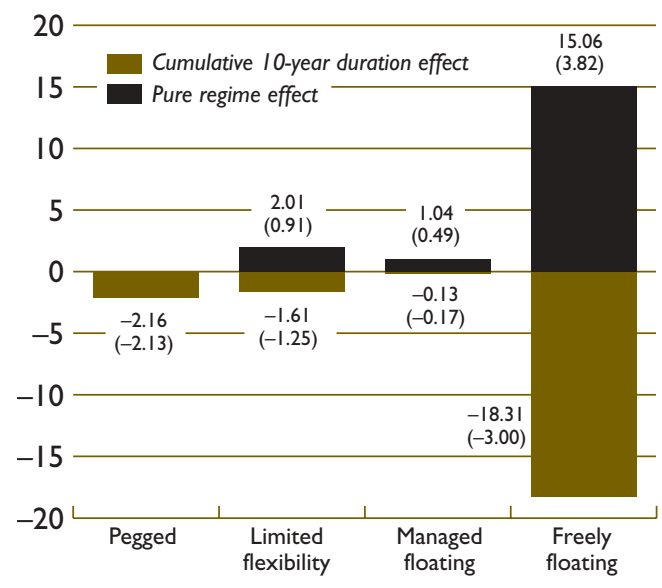

Source: Authors' calculations.

IFigures in parentheses are t-statistics. The bars depict differences in performance relative to pegged exchange rate regimes, conditioning on a range of other variables. See appendix in Section III for details.

2Measured as the additional inflation benefit from maintaining a given regime for 10 years.

less-demanding period, they were often able to maintain the pegs even with greater exposure to international capital. Those countries seeking to establish credibility in the current context, however, are likely to find that a more challenging task.

\section{Learning to Float}

What does the future hold for emerging markets, particularly middle-income, open-capital account countries? These rigid regimes run the risk of triggering crises, and concerns arising from large movements or excessive volatility of the exchange rate limit the extent of flexibility that policymakers are willing to allow. These countries currently manage their exchange rates to varying degrees while pursuing domestic monetary policies-increasingly some variant of inflation targeting-to anchor inflationary expectations. The finding reported earlier that floating becomes a superior alternative as institutional capabilities become stronger raises the possibility that the more developed emerging market economies may wish to anticipate a further move to floating and hence begin to invest in learning to float.
Opposing views exist on the feasibility of learning to float. One fairly pessimistic view (Eichengreen, Hausmann, and Panizza, 2004) hold that the risk of a sharp depreciation under floating rates will depress investment activity in most emerging markets because (unhedged) foreign currency borrowing will always be significant. This handicap, the authors argue, cannot be overcome without coordinated international action to facilitate countries' borrowing in their own currency. As a result, floating exchange rates, in this view, will remain mostly a mirage.

Another perspective starts by noting that floating is relatively new, and the experience with it thus far has been fairly positive (Edwards and Savastano, 1999; and Larraín and Velasco, 2001). While in practice emerging market floaters are far from pure, in that intervention is common and the authorities generally take the exchange rate directly into account in setting monetary policy, there has been meaningful and in some ways effective floating. Inflation objectives have been met and countercyclical policy has been possible. Goldstein (2002) summarizes the available evidence as suggesting that emerging markets can conduct floating in combination with inflation-targeting monetary policy and measures to discourage currency mismatch in a way that credibly achieves low inflation; buffers external shocks, such as to the terms-of-trade; and provides some independence of monetary policy. Ho and McCauley (2003) argue, in their review of recent experience that where exchange rate considerations have been opposed to inflation targets, inflation has typically been the primary objective of policy. ${ }^{56}$

There is reason to believe emerging market economies can improve the flexibility and effectiveness of their floats over time. Such learning to float could take place through two main channels. The first is through the acquisition of confidence and experience on the part of the authorities. The authorities themselves need to learn how to conduct monetary policy appropriate to a flexible exchange rate. It may take time, for example, for the central bank to refine the new internal procedures and communication strategies involved in inflation targeting. Moreover, the authorities may need time and experience to build trust in their own framework and to become comfortable with allowing substantial exchange rate flexibility. The second is through modified behavior on the part of private agents, who may adjust their behavior as they observe flexible exchange rates in action and come to appreciate the risks involved in unhedged for-

${ }^{56}$ See also Goldstein and Turner (2004); Berg, Borensztein, and Mauro (2002); Goldfajn, and Olivares (2001), and references therein for useful surveys. See also Schmidt-Hebbel and Werner (2002) on the experiences of Chile, Mexico, and Brazil. 
eign exchange positions. This adjustment in behavior would, in turn, reduce banking system dollarization as lenders and borrowers appreciate and price the risks involved in currency mismatch (Ize and LevyYeyati, 2003). Similarly, expectations that the central bank will in fact allow exchange rate flexibility may diminish incentives to accept excessive foreign currency-denominated capital inflows (Caballero and Krishnamurthy, 2002). Finally, as private agents observe that the authorities can keep inflation low in the context of a floating exchange rate regime, their inflation expectations may respond less to movements in the exchange rate, thus reducing the pass-through from exchange rates to inflation. The dynamics associated with learning to float would allow a sort of virtuous circle, at least for those countries that can demonstrate some initial effectiveness in floating. ${ }^{57}$

The experience of at least three emerging market floaters may be consistent with this dynamic. Consider the case of Chile, which in the late 1990s transited from a framework with both an inflation target and an explicit exchange rate band to a more pure form of floating. Chile went through two episodes of exchange rate pressure, in late 1998 and late 2000. In the first episode, associated with the Russian and long-term capital management crises, interest rates increased sharply as the authorities defended the exchange rate within the band. Thus, the weakening exchange rate was accompanied by a sharp interest rate increase, as well as a sharp recession. In the second episode of exchange market pressure, in late 2000, the authorities allowed the currency to float, in line with the new exchange rate arrangement introduced in August 1999, according to which the exchange band was discontinued and intervention was limited to extreme circumstances.

Mexico is another country that has seen inflation come down in the context of a regime that has also become gradually more flexible. Once the immediate postcrisis period was over in 1995 , the authorities paid substantial attention to the exchange rate in the conduct of their monetary policy. Over time, they adopted more formal inflation targeting and allowed substantial movements in the real exchange rate. Inflation and both nominal and real interest rates have come down fairly steadily. Inflation persistence has declined over time, suggesting perhaps an increasing credibility of the monetary authorities. ${ }^{58}$ At the same time, Martínez and Werner (2002) conclude that the

\footnotetext{
${ }^{57}$ Many authors, including Mussa and others (2000), Goldstein (2002), and Jeanne (2003), have noted that implementing a floating exchange rate regime with a credible monetary policy may in turn increase the effectiveness of floating. Also, as countries are more successful in floating their currencies, there will be less reason to keep exchange controls that are not necessary.

${ }^{58}$ See Carstens and Werner (2000), and Edwards and Savastano (1998).
}

exposure of Mexican firms to devaluation risk has lessened with the flexible exchange rate regime in place since the 1994/1995 crisis.

Finally, Brazil is a third country that has been floating its exchange rate while at the same time building a track record of low and stable inflationary expectations through inflation targeting. Fraga, Goldfajn, and Minella (2003) describe the challenges associated with building credibility in an environment that is characterized by significant volatility. It notes that in an emerging market environment exchange rate policy and inflation targeting cannot be easily dissociated because a history of monetary instability tends to make the exchange rate a focal point for inflationary expectations, and foreign currency borrowing subjects domestic firms and financial institutions to significant risks. The authors recommend a gradual learning process that includes high levels of communications and transparency on the part of the central bank.

\section{Appendix. \\ Data and Regression Results for Economic Performance Analysis}

This appendix describes the data used in Section III and reports the detailed regression results that lie behind the key findings discussed with respect to economic performance across exchange rate regimes.

Much of the data are taken from Ghosh, Gulde, and Wolf (2003), including the de jure classification of exchange rate regimes, the three measures of economic performance (inflation, growth, growth volatility), and the control (or explanatory) variables used in the regression analysis. Each variable is covered at an annual frequency from 1970 to 1999 for up to 158 countries. The control variables are drawn from the literature and are thought to provide a suitable explanation of the variations in the performance measures. Table A3.1 provides a detailed description of the data. It lists each variable, provides a brief description, and notes which of the subsequent regressions feature these variables. Using this data has the advantage of allowing the evaluation of performance under the Natural classification to be directly compared to a well-respected baseline that assesses performance across the de jure regimes.

Three groups of variables are not covered in the Ghosh, Gulde, and Wolf (2003) data. The first group is the Natural regime classification, available at an annual frequency from http://www.puaf.umd.edu/faculty/papers/reinhart/papers.htm. ${ }^{59}$ The second group is the crisis variables. The banking crisis variable is taken from Demirgüç-Kunt and Detragiache (1998).

${ }^{59}$ The data are also available at monthly frequency. 


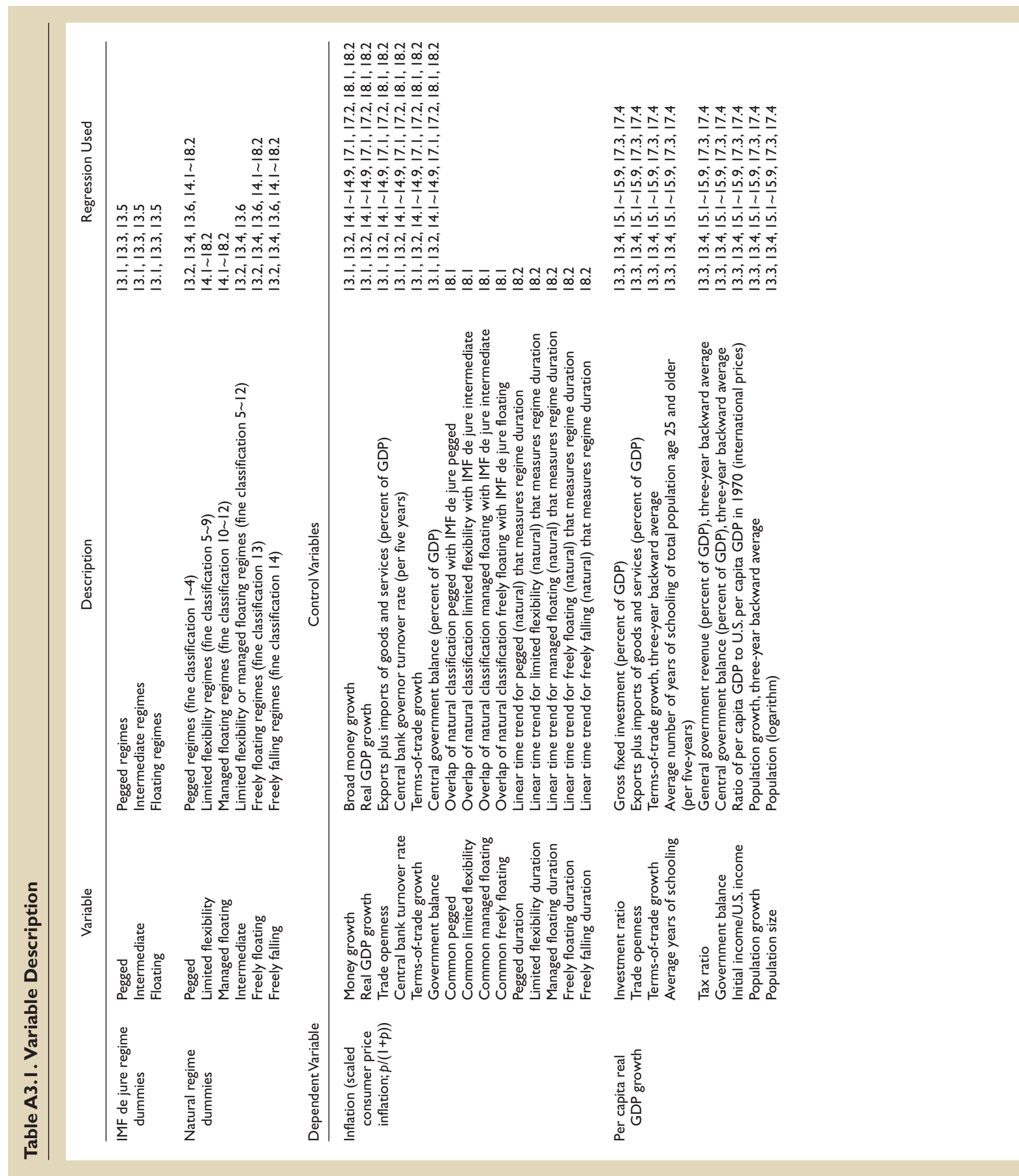




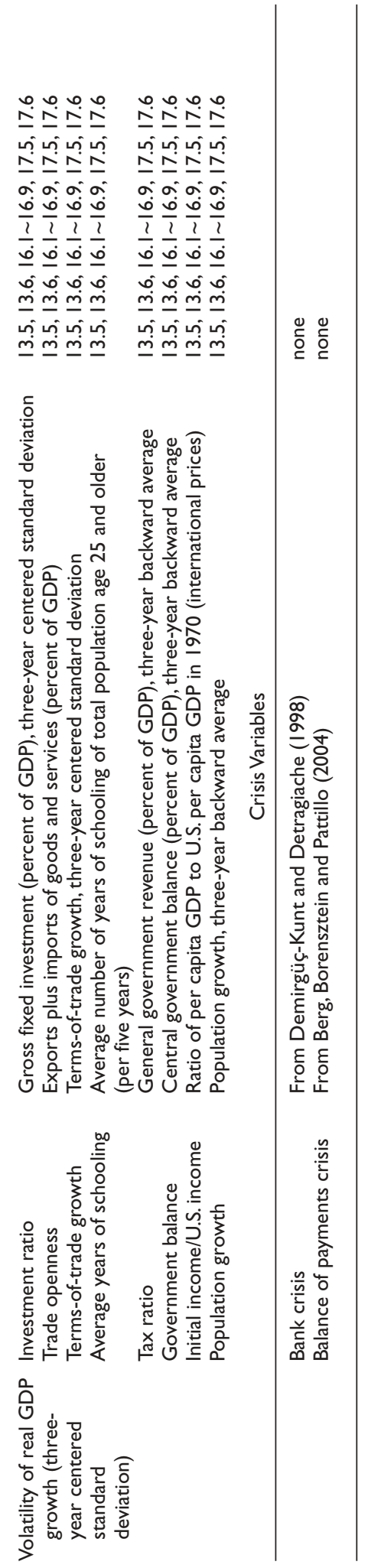


Table A3.2. List of Countries

\begin{tabular}{|c|c|c|c|c|}
\hline $\begin{array}{l}\text { Advanced } \\
\text { Countries }\end{array}$ & Emerging Markets ${ }^{\prime}$ & & loping Countries & \\
\hline $\begin{array}{l}\text { Australia } \\
\text { Austria } \\
\text { Belgium } \\
\text { Canada } \\
\text { Cyprus } \\
\text { Denmark } \\
\text { Finland } \\
\text { France } \\
\text { Germany } \\
\text { Greece } \\
\text { Hong Kong SAR } \\
\text { Iceland } \\
\text { Ireland } \\
\text { Italy } \\
\text { Japan } \\
\text { Kuwait } \\
\text { Luxembourg } \\
\text { Netherlands } \\
\text { New Zealand } \\
\text { Norway } \\
\text { Portugal } \\
\text { Qatar } \\
\text { Singapore } \\
\text { Slovenia } \\
\text { Spain } \\
\text { Sweden } \\
\text { Switzerland } \\
\text { United Arab Emirates } \\
\text { United Kingdom } \\
\text { United States }\end{array}$ & $\begin{array}{l}\text { Argentina } \\
\text { Brazil } \\
\text { Chile } \\
\text { China } \\
\text { Colombia } \\
\text { Czech Republic } \\
\text { Egypt } \\
\text { Hungary } \\
\text { India } \\
\text { Indonesia } \\
\text { Israel } \\
\text { Jordan } \\
\text { Korea, Republic of } \\
\text { Malaysia } \\
\text { Mexico } \\
\text { Morocco } \\
\text { Pakistan } \\
\text { Peru } \\
\text { Philippines } \\
\text { Poland } \\
\text { Rep. Bolivariana de } \\
\text { Venezuela } \\
\text { Russian Federation } \\
\text { South Africa } \\
\text { Thailand } \\
\text { Turkey }\end{array}$ & $\begin{array}{l}\text { Albania } \\
\text { Algeria } \\
\text { Antigua and Barbuda } \\
\text { Armenia } \\
\text { Azerbaijan } \\
\text { Bahrain, Kingdom of } \\
\text { Bangladesh } \\
\text { Barbados } \\
\text { Belarus } \\
\text { Belize } \\
\text { Benin } \\
\text { Bolivia } \\
\text { Bosnia and Herzegovina } \\
\text { Botswana } \\
\text { Bulgaria } \\
\text { Burkina Faso } \\
\text { Burundi } \\
\text { Cameroon } \\
\text { Cape Verde } \\
\text { Central African Republic } \\
\text { Chad } \\
\text { Comoros } \\
\text { Congo, Dem. Rep. of } \\
\text { Congo, Rep. of } \\
\text { Costa Rica } \\
\text { Côte d'lvoire } \\
\text { Djibouti } \\
\text { Dominica } \\
\text { Dominican Republic } \\
\text { Ecuador } \\
\text { El Salvador } \\
\text { Equatorial Guinea } \\
\text { Estonia } \\
\text { Ethiopia } \\
\text { Fiji } \\
\text { Gabon } \\
\text { Gambia,The } \\
\text { Comidis }\end{array}$ & 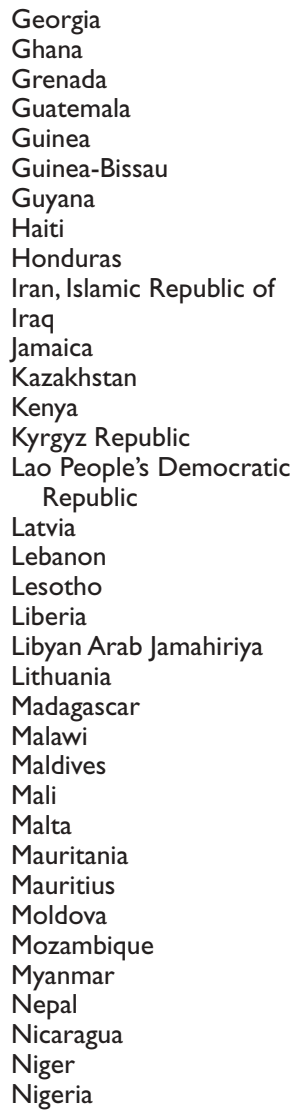 & $\begin{array}{l}\text { Panama } \\
\text { Papua New Guinea } \\
\text { Paraguay } \\
\text { Romania } \\
\text { Rwanda } \\
\text { St. Lucia } \\
\text { St. Vincent and the } \\
\quad \text { Grenadines } \\
\text { Samoa } \\
\text { Senegal } \\
\text { Seychelles } \\
\text { Sierra Leone } \\
\text { Slovak Republic } \\
\text { Sri Lanka } \\
\text { Sudan } \\
\text { Suriname } \\
\text { Swaziland } \\
\text { Syrian Arab Republic } \\
\text { Tajikistan } \\
\text { Tanzania } \\
\text { Togo } \\
\text { Tonga } \\
\text { Trinidad and Tobago } \\
\text { Tunisia } \\
\text { Turkmenistan } \\
\text { Uganda } \\
\text { Ukraine } \\
\text { Uruguay } \\
\text { Vietnam } \\
\text { Zambia } \\
\text { Zimbabwe }\end{array}$ \\
\hline
\end{tabular}

'Emerging market economies are those that are included in the Morgan Stanley Capital International (MSCl) index. With the exception of Israel, which is in the $\mathrm{MSCl}$ index, advanced economies are those that are classified as upper-income economies by the World Bank. All other economies constitute the developing countries group.

The authors declare a banking crisis to have occurred when any one of the following four conditions held: nonperforming loans exceeded 10 percent of banking system assets; a bailout cost 2 percent or more of GDP; large-scale nationalization occurred; or other emergency measures, such as bank holidays, deposit freezes, and special guarantees, had to be undertaken. The currency or balance of payments crisis variable is taken from Berg, Borensztein, and Pattillo (2004), which declares a crisis as having occurred when the weighted average of one-month changes in exchange rate and reserves is more than three (country-specific) standard deviations above the country average.

The final group of variables defines whether a country is classified as an advanced economy, an emerging market, or a developing country. Advanced countries are defined using the World Bank definition for upper-income countries, following Ghosh, Gulde, and Wolf (2003). In dividing the rest of the world into two further groups, the analytical distinction of relevance was their degree of exposure to international capital markets. Those considered to have high exposure were classified as emerging markets, and the rest were designated developing. 60 Table A3.2 lists the country composition of the

\footnotetext{
${ }^{60}$ Strictly, since all nonadvanced (non-upper income) countries are commonly referred to as developing, the two categories used in this paper could have been referred to as emerging and other developing.
} 
Table A3.3. Comparing IMF De Jure and Natural Classifications'

\begin{tabular}{|c|c|c|c|c|c|c|}
\hline \multirow{2}{*}{$\begin{array}{l}\text { Dependent Variable } \\
\text { Classification }\end{array}$} & \multicolumn{2}{|c|}{ Inflation } & \multicolumn{2}{|c|}{$\begin{array}{c}\text { Per Capita } \\
\text { Real GDP Growth }\end{array}$} & \multicolumn{2}{|c|}{$\begin{array}{l}\text { Volatility of } \\
\text { Real GDP Growth }\end{array}$} \\
\hline & De jure & Natural & De jure & Natural & De jure & Natural \\
\hline Regression number & 13.1 & 13.2 & 13.3 & 13.4 & 13.5 & 13.6 \\
\hline Intermediate (de jure) & $\begin{array}{l}0.062 \\
(6.58)^{* * * *}\end{array}$ & & $\begin{array}{r}0.000 \\
(-0.05)\end{array}$ & & $\begin{array}{l}-0.001 \\
(-0.31)\end{array}$ & \\
\hline Floating (de jure) & $\begin{array}{c}0.062 \\
(5.13)^{* * * * *}\end{array}$ & & $\begin{array}{c}0.003 \\
(0.57)\end{array}$ & & $\begin{array}{l}0.008 \\
(3.11)^{* * * *}\end{array}$ & \\
\hline Intermediate (natural) & & $\begin{array}{l}0.016 \\
(2.11)^{* *}\end{array}$ & & $\begin{array}{l}0.000 \\
(0.00)\end{array}$ & & $\begin{array}{l}0.005 \\
(1.19)\end{array}$ \\
\hline Freely floating (natural) & & $\begin{array}{l}0.045 \\
(2.91)^{* * * *}\end{array}$ & & $\begin{array}{c}0.004 \\
(0.47)\end{array}$ & & $\begin{array}{c}0.008 \\
(1.24)\end{array}$ \\
\hline Freely falling (natural) & & $\begin{array}{c}0.218 \\
(|3.5|)^{* * * *}\end{array}$ & & $\begin{array}{l}-0.025 \\
(-3.67)^{* * * *}\end{array}$ & & $\begin{array}{l}0.012 \\
(2.69)^{* * * *}\end{array}$ \\
\hline Money growth & $\begin{array}{c}0.113 \\
(0.83)\end{array}$ & $\begin{array}{l}0.132 \\
(1.05)\end{array}$ & & & & \\
\hline Real GDP growth & $\begin{array}{l}-0.958 \\
(-3.40)^{* * *}\end{array}$ & $\begin{array}{l}-0.555 \\
(-2.59)^{* * * *}\end{array}$ & & & & \\
\hline Investment ratio & & & $\begin{array}{l}-0.083 \\
(-2.62)^{* * *}\end{array}$ & $\begin{array}{l}-0.090 \\
(-2.83)^{* * * *}\end{array}$ & $\begin{array}{l}-0.019 \\
(-0.27)\end{array}$ & $\begin{array}{l}-0.012 \\
(-0.17)\end{array}$ \\
\hline Trade openness & $\begin{array}{c}0.022 \\
(1.29)\end{array}$ & $\begin{array}{l}0.027 \\
(1.90)^{*}\end{array}$ & $\begin{array}{c}0.025 \\
(2.47)^{* * *}\end{array}$ & $\begin{array}{l}0.029 \\
(2.94)^{* * * *}\end{array}$ & $\begin{array}{c}0.007 \\
(1.06)\end{array}$ & $\begin{array}{c}0.008 \\
(1.22)\end{array}$ \\
\hline Central bank turnover rate & $\begin{array}{l}0.048 \\
(3.34)^{* * * *}\end{array}$ & $\begin{array}{l}0.026 \\
(2.05)^{* *}\end{array}$ & & & & \\
\hline Terms-of-trade growth & $\begin{array}{l}-0.005 \\
(-0.25)\end{array}$ & $\begin{array}{c}0.007 \\
(0.39)\end{array}$ & $\begin{array}{c}0.030 \\
(2.09)^{* *}\end{array}$ & $\begin{array}{l}0.026 \\
(1.83)^{*}\end{array}$ & $\begin{array}{c}0.019 \\
(2.02)^{* * *}\end{array}$ & $\begin{array}{l}0.019 \\
(2.02)^{* *}\end{array}$ \\
\hline Average years of schooling & & & $\begin{array}{c}0.002 \\
(-0.83)\end{array}$ & $\begin{array}{r}0.002 \\
(-0.60)\end{array}$ & $\begin{array}{c}0.004 \\
(0.93)\end{array}$ & $\begin{array}{c}0.004 \\
(0.82)\end{array}$ \\
\hline Tax ratio & & & $\begin{array}{l}0.004 \\
(0.14)\end{array}$ & $\begin{array}{l}-0.006 \\
(-0.25)\end{array}$ & $\begin{array}{l}-0.010 \\
(-0.76)\end{array}$ & $\begin{array}{l}-0.005 \\
(-0.36)\end{array}$ \\
\hline Government balance & $\begin{array}{l}-0.361 \\
(-4.99)^{* * *}\end{array}$ & $\begin{array}{l}-0.239 \\
(-4.07)^{* * * *}\end{array}$ & $\begin{array}{l}0.008 \\
(0.25)\end{array}$ & $\begin{array}{r}0.004 \\
(-0.11)\end{array}$ & $\begin{array}{l}-0.008 \\
(-0.40)\end{array}$ & $\begin{array}{l}-0.003 \\
(-0.16)\end{array}$ \\
\hline Initial income/U.S. income & & & $\begin{array}{l}-0.063 \\
(-2.5 \mathrm{I})^{* *}\end{array}$ & $\begin{array}{l}-0.064 \\
(-2.39)^{* *}\end{array}$ & $\begin{array}{l}-0.006 \\
(-0.40)\end{array}$ & $\begin{array}{l}-0.008 \\
(0.55)\end{array}$ \\
\hline Population growth & & & $\begin{array}{l}-0.275 \\
(-1.68)^{*}\end{array}$ & $\begin{array}{l}-0.321 \\
(-1.90)^{*}\end{array}$ & $\begin{array}{l}0.123 \\
(1.02)\end{array}$ & $\begin{array}{l}0.1111 \\
(0.91)\end{array}$ \\
\hline Population size & & & $\begin{array}{l}0.013 \\
(1.01)\end{array}$ & $\begin{array}{l}0.015 \\
(1.07)\end{array}$ & & \\
\hline Constant & $\begin{array}{l}0.366 \\
(7.72)^{* * * *}\end{array}$ & $\begin{array}{l}0.090 \\
(1.5 I)\end{array}$ & $\begin{array}{l}0.091 \\
(2.14)^{* *}\end{array}$ & $\begin{array}{l}0.093 \\
(2.07)^{* *}\end{array}$ & $\begin{array}{l}0.032 \\
(3.72)^{* * *}\end{array}$ & $\begin{array}{l}0.031 \\
(2.53)^{* *}\end{array}$ \\
\hline Observations & 1,946 & 1,946 & 1,762 & I,762 & $\mathrm{I}, 878$ & $\mathrm{I}, 878$ \\
\hline R-squared & 0.58 & 0.70 & 0.29 & 0.31 & 0.26 & 0.26 \\
\hline
\end{tabular}

Source: Author's calculations.

'Figures in parentheses are t-statistics; *significant at 10 percent; **significant at 5 percent; ***significant at I percent.

advanced, emerging market, and developing country groups.

To distinguish between emerging and developing economies, exposure to international capital can be determined either in a de jure sense (the extent of formal capital controls in place) or in a de facto sense (the actual exposure a country faces). In the spirit of this paper, a de facto definition was appropriate, an approach also followed by Prasad and others (2003). Because there are no well-defined or generally accepted thresholds of exposure to international capital, the cutoff between high and low exposure can be 


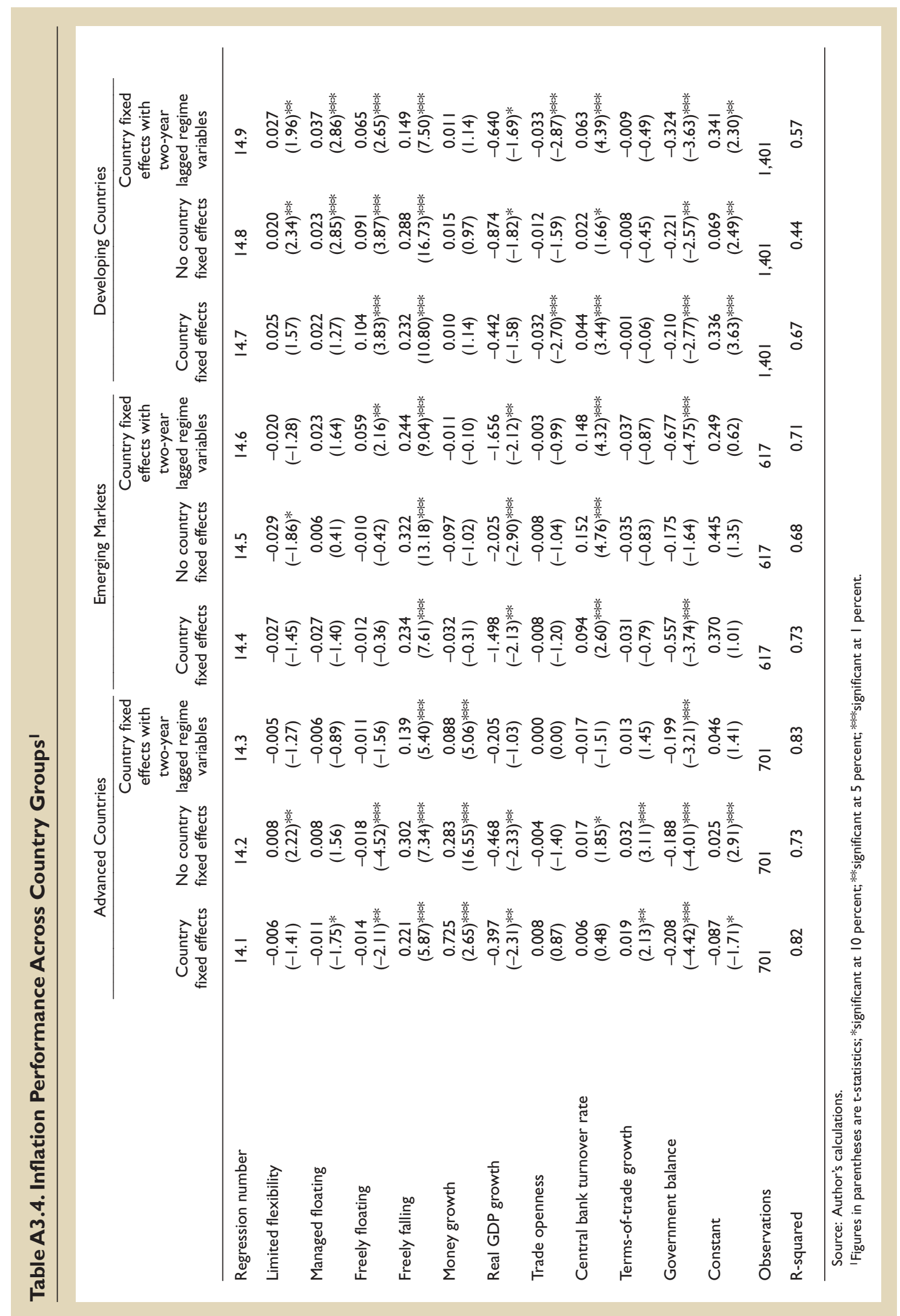




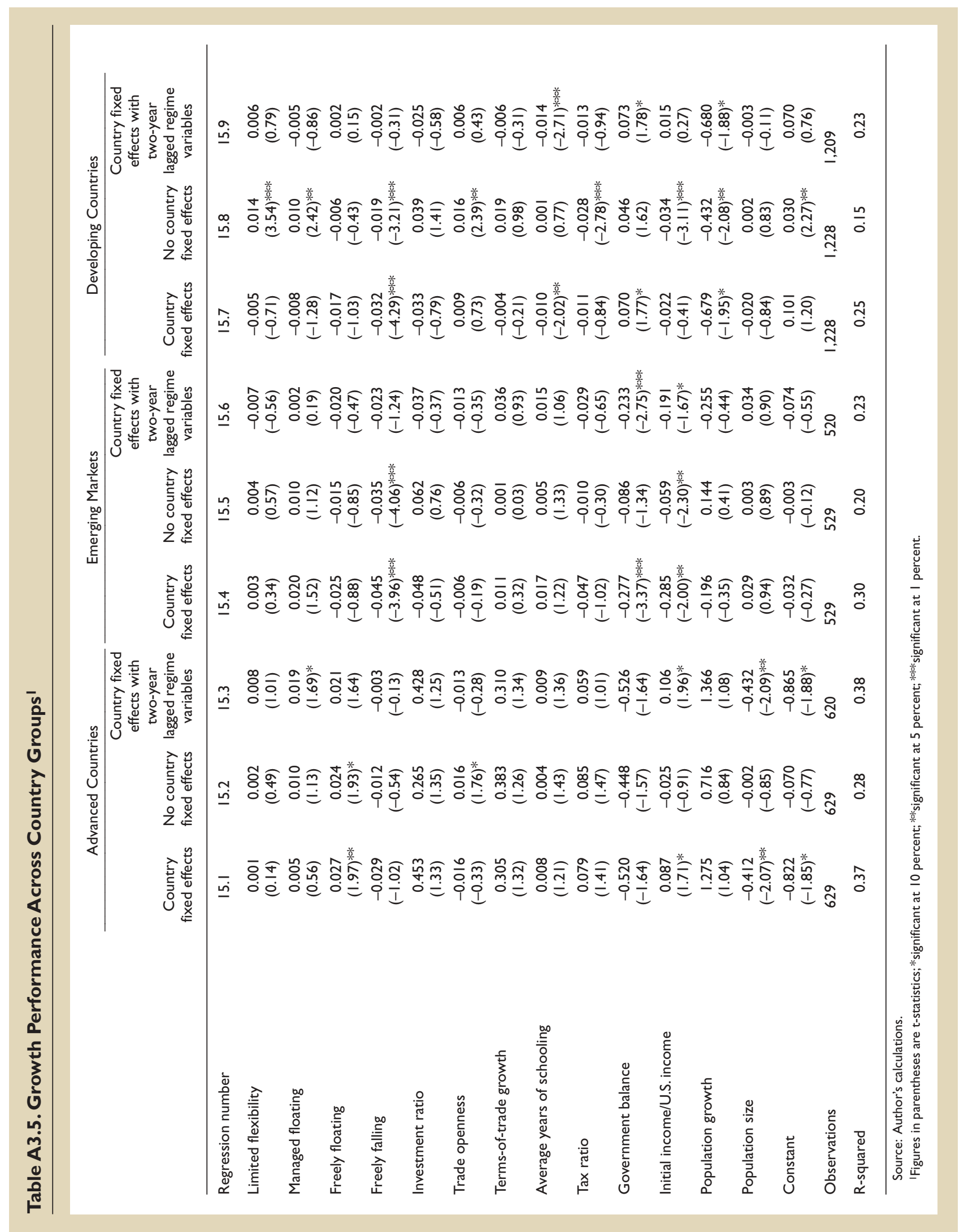




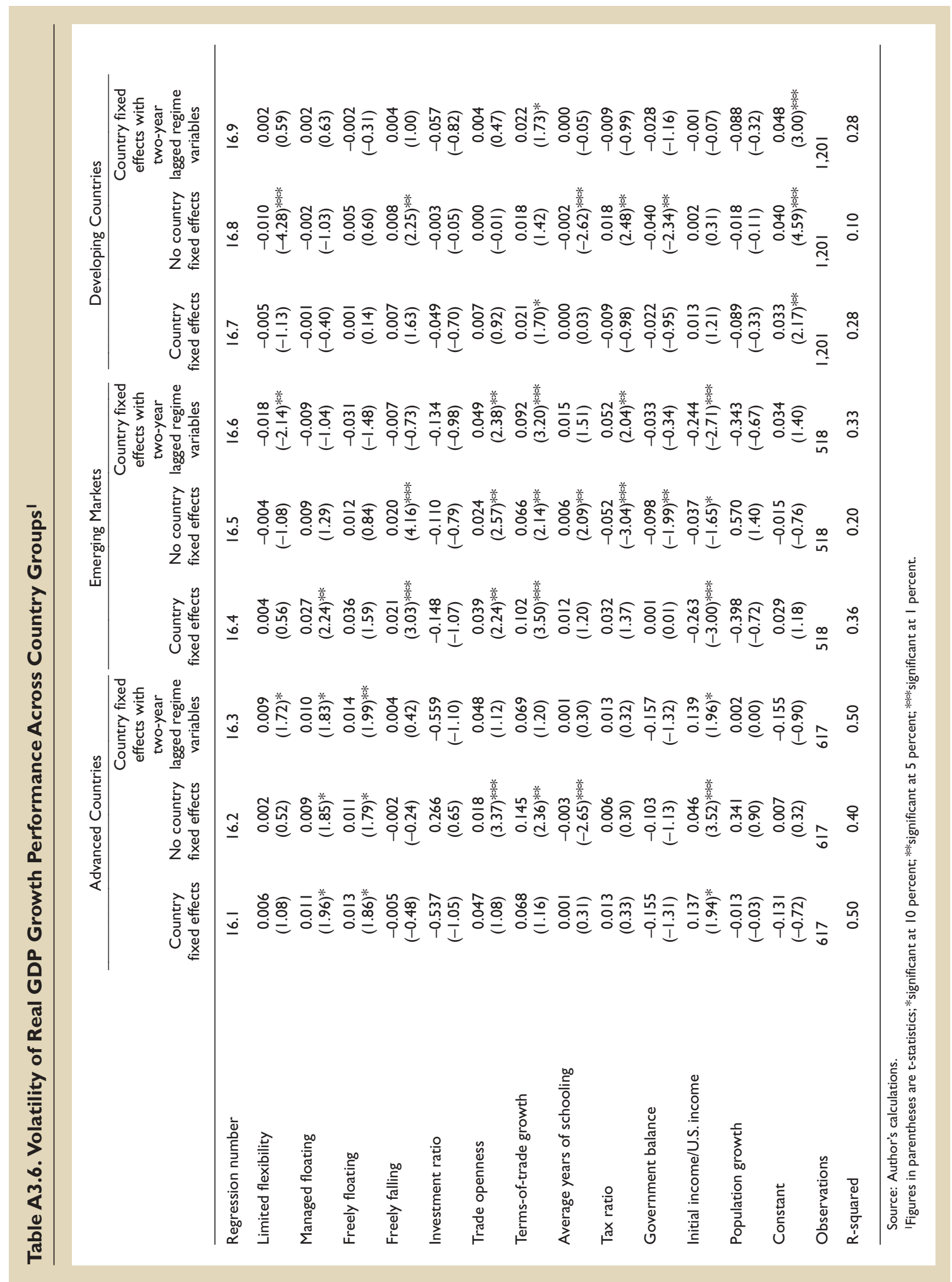


Table A3.7. Emerging Markets in the 1990s 1

\begin{tabular}{|c|c|c|c|c|c|c|}
\hline \multirow[b]{2}{*}{ Dependent Variable } & \multicolumn{2}{|c|}{ Inflation } & \multicolumn{2}{|c|}{ Per Capita GDP Growth } & \multicolumn{2}{|c|}{ Volatility of Real GDP Growth } \\
\hline & No lag & $\begin{array}{l}\text { Two-year lagged } \\
\text { regime variables }\end{array}$ & No lag & $\begin{array}{l}\text { Two-year lagged } \\
\text { regime variables }\end{array}$ & No lag & $\begin{array}{l}\text { Two-year lagged } \\
\text { regime variables }\end{array}$ \\
\hline Regression number & I7.I & 17.2 & 17.3 & 17.4 & 17.5 & 17.6 \\
\hline Limited flexibility & $\begin{array}{l}-0.028 \\
(-0.74)\end{array}$ & $\begin{array}{l}0.003 \\
(0.11)\end{array}$ & $\begin{array}{l}0.005 \\
(0.38)\end{array}$ & $\begin{array}{l}-0.029 \\
(-0.95)\end{array}$ & $\begin{array}{l}-0.011 \\
(-1.14)\end{array}$ & $\begin{array}{c}-0.035 \\
(-1.87)^{*}\end{array}$ \\
\hline Managed floating & $\begin{array}{l}-0.055 \\
(-1.25)\end{array}$ & $\begin{array}{l}0.011 \\
(0.34)\end{array}$ & $\begin{array}{l}0.008 \\
(0.54)\end{array}$ & $\begin{array}{l}-0.026 \\
(-0.80)\end{array}$ & $\begin{array}{c}0.024 \\
(2.52)^{* *}\end{array}$ & $\begin{array}{l}-0.030 \\
(-1.33)\end{array}$ \\
\hline Freely floating & $\begin{array}{l}-0.036 \\
(-0.59)\end{array}$ & $\begin{array}{l}0.213 \\
(2.74)^{* * * *}\end{array}$ & $\begin{array}{l}-0.039 \\
(-0.92)\end{array}$ & $\begin{array}{l}-0.019 \\
(-0.34)\end{array}$ & $\begin{array}{l}-0.011 \\
(-0.30)\end{array}$ & $\begin{array}{l}-0.090 \\
(-1.69)^{*}\end{array}$ \\
\hline Freely falling & $\begin{array}{l}0.137 \\
(1.99)^{* *}\end{array}$ & $\begin{array}{l}0.187 \\
(3.46)^{* * * *}\end{array}$ & $\begin{array}{l}-0.056 \\
(-3.15)^{* * * *}\end{array}$ & $\begin{array}{l}-0.020 \\
(-0.67)\end{array}$ & $\begin{array}{l}0.023 \\
(2.11)^{* * *}\end{array}$ & $\begin{array}{l}-0.034 \\
(-1.55)\end{array}$ \\
\hline Money growth & $\begin{array}{c}0.034 \\
(2.24)^{* * *}\end{array}$ & $\begin{array}{l}0.034 \\
(2.4 I)^{* *}\end{array}$ & & & & \\
\hline Real GDP growth & $\begin{array}{l}-1.096 \\
(-1.10)\end{array}$ & $\begin{array}{l}-2.207 \\
(-1.65)\end{array}$ & & & & \\
\hline Investment ratio & & & $\begin{array}{l}-0.781 \\
(-3.28)^{* * * *}\end{array}$ & $\begin{array}{l}-0.581 \\
(-3.00)^{* * *}\end{array}$ & $\begin{array}{l}-0.954 \\
(-1.70)^{*}\end{array}$ & $\begin{array}{l}-0.622 \\
(-1.29)\end{array}$ \\
\hline Trade openness & $\begin{array}{l}0.229 \\
(2.78)^{* * * *}\end{array}$ & $\begin{array}{l}0.341 \\
(3.24)^{* * * *}\end{array}$ & $\begin{array}{l}-0.053 \\
(-1.15)\end{array}$ & $\begin{array}{l}-0.105 \\
(-2.22)^{* *}\end{array}$ & $\begin{array}{c}0.067 \\
(2.47)^{* *}\end{array}$ & $\begin{array}{c}0.084 \\
(2.42)^{* *}\end{array}$ \\
\hline Central bank turnover rate & $\begin{array}{c}0.074 \\
(1.20)\end{array}$ & $\begin{array}{r}0.067 \\
(0.99)\end{array}$ & & & & \\
\hline Terms-of-trade growth & $\begin{array}{l}0.006 \\
(0.05)\end{array}$ & $\begin{array}{r}0.061 \\
(0.4 I)\end{array}$ & $\begin{array}{l}-0.101 \\
(-1.11)\end{array}$ & $\begin{array}{l}-0.062 \\
(-0.63)\end{array}$ & $\begin{array}{l}0.133 \\
(1.84)^{*}\end{array}$ & $\begin{array}{l}0.160 \\
(2.06)^{* *}\end{array}$ \\
\hline Average years of schooling & & & $\begin{array}{l}0.030 \\
(1.02)\end{array}$ & $\begin{array}{l}0.031 \\
(1.28)\end{array}$ & $\begin{array}{l}0.049 \\
(2.56)^{* *}\end{array}$ & $\begin{array}{l}0.045 \\
(2.63)^{* * * *}\end{array}$ \\
\hline Tax ratio & & & $\begin{array}{l}-0.382 \\
(-2.87)^{* * * *}\end{array}$ & $\begin{array}{l}-0.278 \\
(-2.01)^{* *}\end{array}$ & $\begin{array}{l}0.033 \\
(0.45)\end{array}$ & $\begin{array}{l}-0.088 \\
(-1.13)\end{array}$ \\
\hline Government balance & $\begin{array}{l}-0.628 \\
(-1.24)\end{array}$ & $\begin{array}{l}-0.624 \\
(-1.15)\end{array}$ & $\begin{array}{l}0.452 \\
(2.02)^{* *}\end{array}$ & $\begin{array}{c}0.395 \\
(1.90)^{*}\end{array}$ & $\begin{array}{l}-0.268 \\
(-1.44)\end{array}$ & $\begin{array}{l}-0.326 \\
(-1.46)\end{array}$ \\
\hline Initial income/U.S. income & & & $\begin{array}{l}-1.788 \\
(-2.67)^{* * * *}\end{array}$ & $\begin{array}{l}-1.973 \\
(-3.16)^{* * *}\end{array}$ & $\begin{array}{l}-0.555 \\
(-3.94)^{* * * *}\end{array}$ & $\begin{array}{l}-0.454 \\
(-3.87)^{* * * *}\end{array}$ \\
\hline Population growth & & & $\begin{array}{l}-1.418 \\
(-0.75)\end{array}$ & $\begin{array}{l}-1.561 \\
(-0.93)\end{array}$ & $\begin{array}{l}-1.894 \\
(-1.44)\end{array}$ & $\begin{array}{l}-1.613 \\
(-1.45)\end{array}$ \\
\hline Population size & & & $\begin{array}{l}-0.829 \\
(-2.82)^{* * * *}\end{array}$ & $\begin{array}{l}-0.977 \\
(-3.4 \mathrm{I})^{* * *}\end{array}$ & & \\
\hline Constant & $\begin{array}{l}0.148 \\
(1.25)\end{array}$ & $\begin{array}{l}0.240 \\
(1.68)^{*}\end{array}$ & $\begin{array}{l}4.027 \\
(3.06)^{* * * *}\end{array}$ & $\begin{array}{l}4.507 \\
(3.50)^{* * *}\end{array}$ & $\begin{array}{l}-0.099 \\
(-1.64)\end{array}$ & $\begin{array}{l}-0.046 \\
(-0.82)\end{array}$ \\
\hline Observations & 239 & 239 & 230 & 230 & 230 & 230 \\
\hline R-squared & 0.80 & 0.79 & 0.52 & 0.47 & 0.57 & 0.55 \\
\hline
\end{tabular}

Source: Author's calculations.

'Figures in parentheses are t-statistics; *significant at 10 percent; **significant at 5 percent; ****significant at I percent.

arbitrary and was dealt with by dropping and adding countries on the margin to check the robustness of the results. In this paper, the emerging markets are defined using the Morgan Stanley Capital International (MSCI) classification, which designates a country as an emerging market according to a number of factors: GDP per capita, local government regulations, perceived investment risk, foreign owner- ship limits and capital controls, and other factors. The main motivation for using this classification is that it captures the notion that these countries have access to international capital markets. See http://www.msci. com/equity/index.html for more information. In checking for the robustness of results presented, India and China, which are considered to have relatively closed capital accounts, were dropped from the 


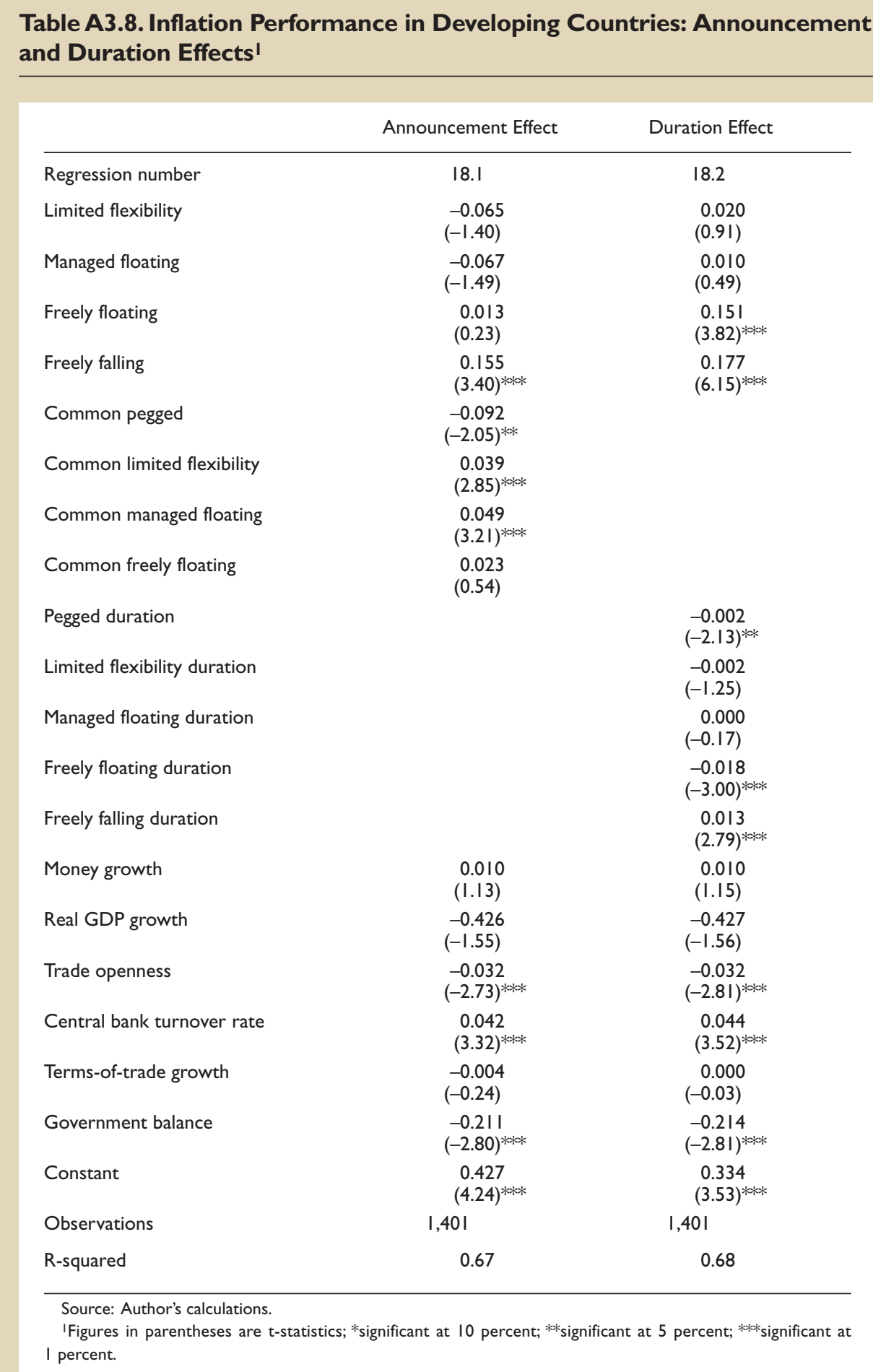

emerging markets sample, but the results were unchanged. Countries added to the list included those that are not on the MSCI index but do appear on other international emerging market indices, and also such countries as Bahrain, Lebanon, and Tunisia that are not on any list but are thought of as relatively open to international capital markets. Again, the results were robust. 
Table A3.9. Robustness Tests

Robustness Test Why do it? Are the results robust?

(I) Drop countries with fewer than I million people

(2) Lag the regime dummies by one year

(3) Drop EMU countries

(4) Run regressions for 1990s only

(5) Replace country fixed effects with political risk (ICRG) measure

(6) Use fine instead of course classification for pegged regimes

(7) Allow for indirect effects on growth via investment and trade openness

(8) Control separately for dual exchange rates in regression with IMF regime dummies
Are small countries driving the results?

Is poor performance after the collapse of regimes attributed to subsequent regimes?

Are the advanced country results driven by the EMU countries?

Are results driven by 1970s and 1980s?

Are the country dummies capturing differences in institutional development across advanced and developing countries?

Does economic performance vary across different pegged regimes? Are pegs associated with more investment Yes. and greater trade openness and do they therefore grow faster?

Are dual exchange rates harmful above and beyond the declared regime?
Yes.

Yes, for inflation. For volatility in emerging markets, lagging the regime dummies eliminates the link between volatility and flexibility of regime, suggesting that the volatility attributed to flexibility is a spillover from the rigid regime.

Yes.

Yes, but significance falls sharply because of fewer observations.

The results remain robust with the additional finding that in advanced

countries, inflation is lower the greater is political stability. In developing countries, ICRG variable matters little.

Yes. More rigidity is associated with lower inflation in developing countries.

The inflation benefit of pegs and intermediate regimes is substantially reduced in the presence of dual rates.

All regressions include time dummies to control for global shocks (oil shocks, G-3 currency volatility) and country dummies to control for institutional differences across countries that might otherwise be attributed to the regime dummies.

All regressions seek to identify the effects of the exchange rate regime, conditional on-or after taking into account - the influence of the conventional control variables relevant to that performance measure. All regressions also include two additional controls, which are not reported for brevity. First, common shocks across countries, such as spikes in oil prices or changes in the volatility of G-3 currencies, are controlled for through time dummies. Second, to control for unobserved, country-specific characteristics that are constant over time, country dummies are included. The implication of this approach is that regime performance is judged by changes that occur within a country rather than across countries. For comparison, however, this appendix also discusses below results without country fixed effects, hence taking into account differences across countries.

To briefly recap, the figures presented in Section III are based on these regressions. They present the coefficients on dummy, or categorical, variables representing the exchange rate regime. The dummy variable takes the value 1 if the exchange rate regime prevails in a country in a particular year; otherwise, it is assigned a value of zero. As is well known, when a set of dummy variables represents the full range of possibilities - in this case, the full range of exchange rate regimes - then regression analysis requires one of the possibilities to be left out. The regime that is left out is the base against which the others are compared. Hence, the coefficients presented in figures are to be interpreted as measures of performance (relative to the excluded pegged regime) and conditional upon the other included variables in the regression.

Table A3.3 (see page 41) compares economic performance (inflation, growth, and growth volatility) across regimes, contrasting the de jure classification with the Natural classification. Table A3.4 (see page 42) evaluates inflation performance across all countries: advanced, emerging market, and developing. Three different specifications are presented: the estimates with country markets fixed effects, on which the figures in the main text are based; the same specification but without fixed effects; and a specification with fixed effects but with the regime variables lagged by two years. The lagging of the exchange 
rate regime variables increases the likelihood, though does not ensure, that the results are reflecting the influence of regimes on performance rather than the other way around. Tables A3.5 and A3.6 (see pages 43 and 44) are analogous, except that they examine growth and growth volatility, respectively. The different specifications show that the qualitative direction of the key results presented in the main text hold up with remarkable consistency. Where the results across specifications are not similar-as for inflation in advanced countries or inflation and volatility in emerging markets-these are discussed in the text.

Table A3.7 (see page 45) reports results for emerging markets in the 1990s and shows that exposure to international capital markets became widespread mainly in that decade. Table A3.8 (see page 46) reports the inflation regression results, which include regime-specific announcement and duration variables. Finally, Table A3.9 (see page 47) summarizes all other robustness tests, which have been omitted for brevity. 


\section{Summary}

F or developing economies, the restrictive pegged and intermediate regimes appear to deliver lower inflation at apparently little cost in terms of lost growth or higher volatility. Thus, it is not surprising that few developing economies truly float, consistent with the Calvo and Reinhart (2002) hypothesis of fear of floating. In particular, the view that intermediate regimes are an endangered species is belied by their persistence (as discussed in Section II), while their performance is not dominated by either of the polar regimes.

A strong case emerges for embracing greater exchange rate flexibility as countries grow richer. With economic advancement, the inflation benefit of pegged and intermediate regimes is lost, perhaps because policy credibility and track record are well established. At the same time, the risk associated with exchange rate flexibility declines as it becomes easier for governments and private agents to borrow in their own currencies. Also growth performance is substantially superior under free floats.

While developing and emerging market economies may prepare for the prospect of floating exchange rates as their institutional progress allows them to do so, they can gain more from the regimes that they do adopt. For developing countries, the inflation benefit associated with exchange rate pegs is greatest if it is an explicit, publicly announced policy goal. In addition, pegged regimes benefit from establishing a successful track record over time, which necessitates consistent macroeconomic policies. Case studies from middle-income countries with open capital accounts show that the fear of floating can be overcome by an investment in learning to float. Thus, though history may lead countries to adopt particular regimes, they can improve the performance of those regimes by learning to manage them better over time. 


\section{References}

Alesina, Alberto, and Alexander Wagner, 2003, "Choosing (and Reneging on) Exchange Rate Regimes," NBER Working Paper 9809 (Cambridge, Massachusetts: National Bureau of Economic Research, June).

Bailliu, Jeannine, Robert Lafrance, and Jean-François Perrault, 2002, "Does Exchange Rate Policy Matter for Growth?" Bank of Canada Working Paper 2002-17.

Baxter, Marianne, and Alan Stockman, 1989, "Business Cycles and the Exchange-Rate Regime: Some International Evidence," Journal of Monetary Economics, Vol. 23 (May), pp. 377-400.

Berg, Andrew G., Eduardo R. Borensztein, and Paolo Mauro, 2002, "An Evaluation of Monetary Regime Options for Latin America," North American Journal of Economics and Finance, Vol. 13 (December), pp. 213-35.

Berg, Andrew, Eduardo R. Borensztein, and Catherine A. Pattillo, 2004, "Assessing Early Warning Systems: How Have They Worked in Practice?" IMF Working Paper (Washington: International Monetary Fund; forthcoming).

Berger, Helge, Jan-Egbert Sturm, and Jakob de Haan, 2000, "An Empirical Investigation into Exchange Rate Regime Choice and Exchange Rate Volatility," CESifo Working Paper No. 263. Also available on the Internet at http://www.cesifo.de.

Bordo, Michael D., 2003, "Exchange Rate Regime Choice in Historical Perspective," NBER Working Paper 9654 (Cambridge, Massachusetts: National Bureau of Economic Research)

—, and Marc Flandreau, 2001, "Core, Periphery, Exchange Rate Regimes, and Globalization," NBER Working Paper 8584 (Cambridge, Massachusetts: National Bureau of Economic Research, November).

Bordo, Michael D., and others, 2001, "Financial Crises: Lessons from the Last 120 Years," Economic Policy: A European Forum, No. 32 (April), pp. 51-82.

Bosco, Luigi, 1987, "Determinants of the Exchange Rate Regimes in LDCs: Some Empirical Evidence," Economic Notes, Vol. 0, pp. 119-43.

Broda, Christian, 2001, "Coping with Terms-of-Trade Shocks: Pegs Versus Floats," American Economic Review, Papers and Proceedings, Vol. 91 (May), pp. 376-80.

Bubula, Andrea, and Inci Ötker-Robe, 2002, "The Evolution of Exchange Rate Regimes Since 1990: Evidence from De Facto Policies," IMF Working Paper 02/155 (Washington: International Monetary Fund)
_ 2003, "Are Pegged and Intermediate Exchange Regimes More Crisis Prone?" IMF Working Paper 03/223 (Washington: International Monetary Fund).

Caballero, Ricardo J., and Arvind Krishnamurthy, 2002, "A 'Vertical' Analysis of Monetary Policy in Emerging Markets," IMF Seminar Series, No. 69 (Washington: International Monetary Fund).

Calomiris, Charles W., 1998, “The IMF's Imprudent Role as Lender of Last Resort," Cato Journal, Vol. 17 (Winter), pp. 275-94.

Calvo, Guillermo A., 1999, "Fixed Versus Flexible Exchange Rates: Preliminaries of a Turn-of-Millennium Rematch," unpublished.

_ Quarterly Journal of Economics, Vol. 117 (May), pp. 379-408.

Carstens, Agustín, and Alejandro Werner, 2000, "Monetary Policy and Exchange Rate Choices for Mexico," Cuadernos de Economía (Pontifical Catholic University of Chile), Vol. 37 (April), pp. 139-75.

Celasun, Oya, 2003, "Exchange Rate Regime Considerations in an Oil Economy: The Case of the Islamic Republic of Iran,” IMF Working Paper 03/26 (Washington: International Monetary Fund).

Collins, Susan M., 1996, "On Becoming More Flexible: Exchange Rate Regimes in Latin America and the Caribbean," Journal of Development Economics, Vol. 51 (October), pp. 117-38.

Corbo, Vittorio, Oscar Landerretche, and Klaus SchmidtHebbel, 2001, "Assessing Inflation Targeting After a Decade of World Experience," International Journal of Finance and Economics, Vol. 6 (October), pp. 343-68.

Cuddington, John T., and Samuel K. Otoo, 1990, "Choice of Exchange Rate Regime: A Multinomial Logit Model," Georgetown University Working Paper No. 90-18 (Washington: Georgetown University).

_ 1991, "Analysis of the Choice of Exchange Rate Regimes in the 1980s," Georgetown University Working Paper No. 91-02 (Washington: Georgetown University).

Demirgüç-Kunt, Asli, and Enrica Detragiache, 1998, "The Determinants of Banking Crises in Developing and Developed Countries, IMF Staff Papers, Vol. 25 (Washington: International Monetary Fund).

Dornbusch, Rudiger, 2001, "Fewer Monies, Better Monies," NBER Working Paper 8324 (Cambridge, Massachusetts: National Bureau of Economic Research) 
Dreyer, Jacob S., 1978, "Determinants of Exchange Rate Regimes for Currencies of Developing Countries: Some Preliminary Results," World Development, Vol. 6 (April), pp. 437-45.

Duttagupta, Rupa, and İnci Ötker-Robe, 2003, "Exits from Pegged Regimes: An Empirical Analysis," IMF Working Paper 03/147 (Washington: International Monetary Fund).

Edison, Hali J., and Michael Melvin, 1990, "The Determinants and Implications of an Exchange Rate System," in Monetary Policy for a Volatile Global Economy, ed. by William S. Haraf, and Thomas D. Willet (Washington: AEI Press).

Edwards, Sebastian, 1996, "The Determinants of the Choice Between Fixed and Flexible ExchangeRate Regimes," NBER Working Paper 5756 (Cambridge, Massachusetts: National Bureau of Economic Research).

- 1999, "The Choice of Exchange Rate Regime in Developing and Middle Income Countries," in Changes in Exchange Rates in Rapidly Developing Countries: Theory, Practice, and Policy Issues, ed. by Takatoshi Ito and Anne O. Krueger, NBER-East Asia Seminars on Economics, Vol. 7 (Chicago and London: University of Chicago Press).

, 2001, "Exchange Rate Regimes, Capital Flows and Crisis Prevention," NBER Working Paper 8529 (Cambridge, Massachusetts: National Bureau of Economic Research).

— change Rates as Shock Absorbers," NBER Working Paper 9867 (Cambridge, Massachusetts: National Bureau of Economic Research).

Edwards, Sebastian, and Igal Magendzo, 2003a, "A Currency of One's Own? An Empirical Investigation on Dollarization and Independent Currency Unions," NBER Working Paper 9514 (Cambridge, Massachusetts: National Bureau of Economic Research).

_ 2003b, "Strict Dollarization and Economic Performance: An Empirical Investigation.” NBER Working Paper 9820 (Cambridge, Massachusetts: National Bureau of Economic Research).

Edwards, Sebastian, and Miguel A. Savastano, 1998, "The Morning After: The Mexican Peso in the Aftermath of the 1994 Currency Crisis," NBER Working Paper 6516 (Cambridge, Massachusetts: National Bureau of Economic Research).

_ 1999, "Exchange Rates in Emerging Economies: What Do We Know? What Do We Need to Know?" NBER Working Paper 7228 (Cambridge, Massachusetts: National Bureau of Economic Research).

Eichengreen, Barry, 1994, International Monetary Arrangements for the $21^{\text {st }}$ Century (Washington: Brookings Institution).

- 2001, "What Problems Can Dollarization Solve?” Journal of Policy Modeling, Vol. 23 (April), pp. 267-77.

$\longrightarrow$, and others, 1998, Exit Strategies: Policy Options for Countries Seeking Greater Exchange Rate Flexibility, IMF Occasional Paper 168 (Washington: International Monetary Fund).

Eichengreen, Barry, Ricardo Hausmann, and Ugo Panizza, 2004, "The Pain of Original Sin, The Mystery of
Original Sin, and Original Sin: The Road to Redemption," forthcoming in Other People's Money: Debt Denomination and Financial Instability in Emerging Market Economies, ed. by Eichengreen and Hausmann (Chicago: University of Chicago Press).

Engel, Charles, and Andrew K. Rose, 2002, "Currency Unions and International Integration," Journal of Money, Credit and Banking, Vol. 34 (November), pp. 1067-89.

Fischer, Stanley, 2001, "Exchange Rate Regimes: Is the Bipolar View Correct?" Distinguished Lecture on Economics in Government, Journal of Economic Perspectives, Vol. 15 (Spring), pp. 3-24.

Flood, Robert P., and Andrew K. Rose, 1995, "Fixing Exchange Rates: A Virtual Quest for Fundamentals," Journal of Monetary Economics, Vol. 36 (August), pp. 3-37.

Fraga, Arminio, Ilan Goldfajn, and Andre Minella, 2003, "Inflation Targeting in Emerging Market Economies," forthcoming, NBER Macroeconomics Annual, Vol. 18. Also available on the Internet at http://www.nber.org/ books/macro18/fraga-et-al6-9-03.pdf.

Frankel, Jeffrey A., 1999, "No Single Currency Regime Is Right for All Countries or at All Times," NBER Working Paper 7338 (Cambridge, Massachusetts: National Bureau of Economic Research).

-, and Andrew Rose, 2002, "An Estimate of the Effect of Common Currencies on Trade and Income," Quarterly Journal of Economics, Vol. 117 (May), pp. 437-66.

Frieden, Jeffry, Piero Ghezzi, and Ernesto Stein, 2001, "Politics and Exchange Rates: A Cross-Country Approach to Latin America," Research Network Working Paper R-421 (Washington: Inter-American Development Bank).

Ghosh, Atish R., and others, 1997, "Does the Nominal Exchange Rate Regime Matter?" NBER Working Paper 5874 (Cambridge, Massachusetts: National Bureau of Economic Research).

Ghosh, Atish, Anne-Marie Gulde, and Holger C. Wolf, 2003, Exchange Rate Regimes: Choices and Consequences (Cambridge, Massachusetts: MIT Press).

Giavazzi, Francesco, and Alberto Giovannini, 1989, Limiting Exchange Rate Flexibility: The European Monetary System (Cambridge, Massachusetts: MIT Press).

Goldfajn, Ilan, and Gino Olivares, 2001, "Can Flexible Exchange Rates Still 'Work' in Financially Open Economies," G-24 Discussion Paper Series No. 8 (New York: United Nations).

Goldstein, Morris, 2002, "Managed Floating Plus," Policy Analyses in International Economics, Vol. 66 (Washington: Institute for International Economics).

_ in Emerging Economies" (Washington: Institute of International Economics, forthcoming).

Hausmann, Ricardo, Ugo Panizza, and Ernesto Stein, 2001, "Why Do Countries Float the Way They Float?," Journal of Development Economics, Vol. 66 (December), pp. 387-414.

Heller, H. Robert, 1978, "Determinants of Exchange Rate Practices," Journal of Money, Credit and Banking, Vol. 10, pp. 308-21. 
Hernández, Leonardo, and Peter Montiel, 2001, "PostCrisis Exchange Rate Policy in Five Asian Countries: Filling in the 'Hollow Middle'?" IMF Working Paper 01/170 (Washington: International Monetary Fund).

Ho, Corrinne, and Robert N. McCauley, 2003, "Living with Flexible Exchange Rates: Issues and Recent Experience in Inflation Targeting Emerging Market Economies," BIS Working Paper No. 130 (Basel, Switzerland: Bank for International Settlements).

Holden, Merle, Paul Holden, and Esther Suss, 1979, "The Determinants of Exchange Rate Flexibility: An Empirical Investigation," Review of Economics and Statistics, Vol. 61 (August), pp. 327-33.

Honkapohja, Seppo, and Pentti Pikkarainen, 1994, "Country Characteristics and the Choice of the Exchange Rate Regime: Are Mini-Skirts Followed by Maxis?" in Exchange Rate Policies in the Nordic Countries, ed. by Johnny Åkerholm and Alberto Giovannini (London: Centre for Economic Policy Research).

International Financial Institution Advisory Commission, 2000, "Report of the International Financial Institution Advisory Commission," submitted to the U.S. Congress and U.S. Department of the Treasuring. Also available on the Internet at http://www.ustreas. gov/press/reports.html.

International Monetary Fund, 1997, "Exchange Rate Arrangements and Economic Performance in Developing Countries," World Economic and Financial Surveys (Washington: International Monetary Fund).

_ 1999, "Exchange Arrangements and Currency Convertibility: Developments and Issues," World Economic and Financial Surveys (Washington: International Monetary Fund).

_ 2003a, "Public Debt and Fiscal Policy in Emerging Market Economies," World Economic and Financial Surveys (Washington: International Monetary Fund).

- 2003b, "Exchange Arrangements and Foreign Exchange Markets: Developments and Issues," World Economic and Financial Surveys (Washington: International Monetary Fund).

- Independent Evaluation Office, 2003c, IMF and Recent Capital Account Crises: Indonesia, Korea, Brazil: Evaluation Report (Washington: International Monetary Fund).

Ize, Alain, and Eduardo Levy-Yeyati, Eduardo, 2003, "Financial Dollarization," Journal of International Economies, Vol. 59 (March), pp. 323-47.

Jeanne, Olivier, 2003, "Why Do Emerging Market Economies Borrow Foreign Currency?" IMF Working Paper 03/177 (Washington: International Monetary Fund).

Juhn, Grace S., and Paolo Mauro, 2002, “Long-Run Determinants of Exchange Rate Regimes: A Simple Sensitivity Analysis," IMF Working Paper 02/104 (Washington: International Monetary Fund).

Kaminsky, Graciela, and Carmen Reinhart, 1999, “The Twin Crises: The Causes of Banking and Balance of Payments Problems," American Economic Review, Vol. 89 (June), pp. 473-500.

Klein, Michael W., and Nancy P. Marion, 1997, "Explaining the Duration of Exchange-Rate Pegs," Journal of Development Economics, Vol. 54 (December), pp. 387-404.

Larraín, Felipe, and Andrés Velasco, 2001, "ExchangeRate Policy in Emerging Market Economies: The Case for Floating," Essays in International Economics, No. 224 (Princeton, New Jersey: Princeton University).

Levy-Yeyati, Eduardo, and Federico Sturzenegger, 2002, "Classifying Exchange Rate Regimes: Deeds Versus Words," Universidad Torcuato Di Tella. Available via the Internet at http://www.utdt.edu/ fsturzen.

, 2003, "To Float or To Fix: Evidence on the Impact of Exchange Rate Regimes on Growth," American Economic Review, Vol. 93 (September), pp. 1173-93.

Martínez, Lorenza, and Alejandro Werner, 2002, "The Exchange Rate Regime and the Currency Composition of Corporate Debt: The Mexican Experience," Journal of Development Economics, Vol. 69 (December), pp. 315-34.

Masson, Paul R., 2001, "Exchange Rate Regime Transitions," Journal of Development Economics, Vol. 64 (April), pp. 571-86.

Mauro, Paolo, and Grace S. Juhn, 2002, "Long-Run Determinants of Exchange Rate Regimes: A Simple Sensitivity Analysis," IMF Working Paper 02/104 (Washington: International Monetary Fund).

Meissner, Christopher, and Nienke Oomes, 2004, "Why Do Countries Peg the Way They Peg?" IMF Working Paper (Washington: International Monetary Fund; forthcoming).

Melvin, Michael, 1985, "Choice of an Exchange Rate System and Macroeconomic Stability," Journal of Money, Credit and Banking, Vol. 17 (November), pp. 467-78.

Mussa, Michael, 1986, "Nominal Exchange Rate Regimes and the Behavior of Real Exchange Rates: Evidence and Implications," Carnegie-Rochester Conference Series on Public Policy, Vol. 25 (Fall), pp.117-214.

, 2002, Argentina and the Fund: From Triumph to Tragedy (Washington: Institute for International Economics).

- , and others, 2000, Exchange Rate Regimes in an Increasingly Integrated World Economy, Occasional Paper 193 (Washington: International Monetary Fund).

Obstfeld, Maurice, and Kenneth Rogoff, 1995, "Mirage of Fixed Exchange Rates," Journal of Economic Perspectives, Vol. 9 (Fall), pp. 73-96.

Poirson, Hélène, 2001, "How Do Countries Choose Their Exchange Rate Regime?" IMF Working Paper 01/46 (Washington: International Monetary Fund).

Prasad, Eswar, and others, 2003, Effects of Financial Globalization on Developing Countries, IMF Occasional Paper 226 (Washington: International Monetary Fund).

Reinhart, Carmen M., 2000, "Mirage of Floating Exchange Rates," American Economic Review, Papers and Proceedings, Vol. 90 (May), pp. 65-70.

, and Kenneth Rogoff, 2004, "The Modern History of Exchange Rate Arrangements: A Reinterpretation," Quarterly Journal of Economics (forthcoming). Available via the Internet at http://www.puaf.umd.edu/ faculty/papers/reinhart/papers.htm. 
, and Antonio Spilimbergo, 2003, "When Hard Shocks Hit Soft Pegs," paper prepared for the 2003 American Economic Association meetings in Washington, D.C.

Rizzo, Jean-Marc, 1998, "The Economic Determinants of the Choice of an Exchange Rate Regime: A Probit Analysis," Economics Letters, Vol. 59 (June), pp. 283-87.

Rogoff, Kenneth, 1999, "Perspectives on Exchange Rate Regimes," in International Capital Flows, ed. by Martin Feldstein, pp. 441-53 (Chicago: University of Chicago Press).

, 2001, "Why Not a Global Currency?" American Economic Review, Papers and Proceedings, Vol. 91 (May), pp. 243-47.

, 2003, "Globalization and Global Disinflation," paper prepared for the Federal Reserve Bank of Kansas City conference, "Monetary Policy and Uncertainty: Adapting to a Changing Economy," Jackson Hole, Wyoming, August 28-30, 2003.
Savvides, Andreas, 1990, "Real Exchange Rate Variability and the Choice of Exchange Rate Regime by Developing Countries," Journal of International Money and Finance, Vol. 9 (December), pp. 440-54.

Schmidt-Hebbel, Klaus, and Alejandro Werner, 2002, "Inflation Targeting in Brazil, Chile, and Mexico: Performance, Credibility, and the Exchange Rate," Economia: Journal of the Latin American and Caribbean Economic Association, Vol. 2 (Spring), pp. 31-89.

Summers, Lawrence H., 2000, "International Financial Crises: Causes, Prevention, and Cures," American Economic Review, Papers and Proceedings, Vol. 90 (May), pp. 1-16.

Tornell, Aaron, and Andrés Velasco, 2000, "Fixed Versus Flexible Exchange Rates: Which Provides More Fiscal Discipline?" Journal of Monetary Economics, Vol. 45 (April), pp. 399-436. 


\section{Recent Occasional Papers of the International Monetary Fund}

229. Evolution and Performance of Exchange Rate Regimes, by Kenneth S. Rogoff, Aasim M. Husain, Ashoka Mody, Robin Brooks, and Nienke Oomes. 2004.

228. Capital Markets and Financial Intermediation in The Baltics, by Alfred Schipke, Christian Beddies, Susan M. George, and Niamh Sheridan. 2004.

227. U.S. Fiscal Policies and Priorities for Long-Run Sustainability, Martin Mühleisen and Christopher Towe, editors. 2004.

226. Hong Kong SAR: Meeting the Challenges of Integration with the Mainland, edited by Eswar Prasad, with contributions from Jorge Chan-Lau, Dora Iakova, William Lee, Hong Liang, Ida Liu, Papa N'Diaye, and Tao Wang. 2004.

225. Rules-Based Fiscal Policy in France, Germany, Italy, and Spain, by Teresa Dában, Enrica Detragiache, Gabriel di Bella, Gian Maria Milesi-Ferretti, and Steven Symansky. 2003.

224. Managing Systemic Banking Crises, by a staff team led by David S. Hoelscher and Marc Quintyn. 2003.

223. Monetary Union Among Member Countries of the Gulf Cooperation Council, by a staff team led by Ugo Fasano. 2003.

222. Informal Funds Transfer Systems: An Analysis of the Informal Hawala System, by Mohammed El Qorchi, Samuel Munzele Maimbo, and John F. Wilson. 2003.

221. Deflation: Determinants, Risks, and Policy Options, by Manmohan S. Kumar. 2003.

220. Effects of Financial Globalization on Developing Countries: Some Empirical Evidence, by Eswar S. Prasad, Kenneth Rogoff, Shang-Jin Wei, and Ayhan Kose. 2003.

219. Economic Policy in a Highly Dollarized Economy: The Case of Cambodia, by Mario de Zamaroczy and Sopanha Sa. 2003.

218. Fiscal Vulnerability and Financial Crises in Emerging Market Economies, by Richard Hemming, Michael Kell, and Axel Schimmelpfennig. 2003.

217. Managing Financial Crises: Recent Experience and Lessons for Latin America, edited by Charles Collyns and G. Russell Kincaid. 2003.

216. Is the PRGF Living Up to Expectations?-An Assessment of Program Design, by Sanjeev Gupta, Mark Plant, Benedict Clements, Thomas Dorsey, Emanuele Baldacci, Gabriela Inchauste, Shamsuddin Tareq, and Nita Thacker. 2002.

215. Improving Large Taxpayers' Compliance: A Review of Country Experience, by Katherine Baer. 2002.

214. Advanced Country Experiences with Capital Account Liberalization, by Age Bakker and Bryan Chapple. 2002.

213. The Baltic Countries: Medium-Term Fiscal Issues Related to EU and NATO Accession, by Johannes Mueller, Christian Beddies, Robert Burgess, Vitali Kramarenko, and Joannes Mongardini. 2002.

212. Financial Soundness Indicators: Analytical Aspects and Country Practices, by V. Sundararajan, Charles Enoch, Armida San José, Paul Hilbers, Russell Krueger, Marina Moretti, and Graham Slack. 2002.

211. Capital Account Liberalization and Financial Sector Stability, by a staff team led by Shogo Ishii and Karl Habermeier. 2002.

210. IMF-Supported Programs in Capital Account Crises, by Atish Ghosh, Timothy Lane, Marianne SchulzeGhattas, Aleš Bulír, Javier Hamann, and Alex Mourmouras. 2002.

209. Methodology for Current Account and Exchange Rate Assessments, by Peter Isard, Hamid Faruqee, G. Russell Kincaid, and Martin Fetherston. 2001.

208. Yemen in the 1990s: From Unification to Economic Reform, by Klaus Enders, Sherwyn Williams, Nada Choueiri, Yuri Sobolev, and Jan Walliser. 2001.

207. Malaysia: From Crisis to Recovery, by Kanitta Meesook, Il Houng Lee, Olin Liu, Yougesh Khatri, Natalia Tamirisa, Michael Moore, and Mark H. Krysl. 2001.

206. The Dominican Republic: Stabilization, Structural Reform, and Economic Growth, by a staff team led by PhilipYoung comprising Alessandro Giustiniani, Werner C. Keller, and Randa E. Sab and others. 2001. 
205. Stabilization and Savings Funds for Nonrenewable Resources, by Jeffrey Davis, Rolando Ossowski, James Daniel, and Steven Barnett. 2001.

204. Monetary Union in West Africa (ECOWAS): Is It Desirable and How Could It Be Achieved? by Paul Masson and Catherine Pattillo. 2001.

203. Modern Banking and OTC Derivatives Markets: The Transformation of Global Finance and Its Implications for Systemic Risk, by Garry J. Schinasi, R. Sean Craig, Burkhard Drees, and Charles Kramer. 2000.

202. Adopting Inflation Targeting: Practical Issues for Emerging Market Countries, by Andrea Schaechter, Mark R. Stone, and Mark Zelmer. 2000.

201. Developments and Challenges in the Caribbean Region, by Samuel Itam, Simon Cueva, Erik Lundback, Janet Stotsky, and Stephen Tokarick. 2000.

200. Pension Reform in the Baltics: Issues and Prospects, by Jerald Schiff, Niko Hobdari, Axel Schimmelpfennig, and Roman Zytek. 2000.

199. Ghana: Economic Development in a Democratic Environment, by Sérgio Pereira Leite, Anthony Pellechio, Luisa Zanforlin, Girma Begashaw, Stefania Fabrizio, and Joachim Harnack. 2000.

198. Setting Up Treasuries in the Baltics, Russia, and Other Countries of the Former Soviet Union: An Assessment of IMF Technical Assistance, by Barry H. Potter and Jack Diamond. 2000.

197. Deposit Insurance: Actual and Good Practices, by Gillian G.H. Garcia. 2000.

196. Trade and Trade Policies in Eastern and Southern Africa, by a staff team led by Arvind Subramanian, with Enrique Gelbard, Richard Harmsen, Katrin Elborgh-Woytek, and Piroska Nagy. 2000.

195. The Eastern Caribbean Currency Union-Institutions, Performance, and Policy Issues, by Frits van Beek, José Roberto Rosales, Mayra Zermeño, Ruby Randall, and Jorge Shepherd. 2000.

194. Fiscal and Macroeconomic Impact of Privatization, by Jeffrey Davis, Rolando Ossowski, Thomas Richardson, and Steven Barnett. 2000.

193. Exchange Rate Regimes in an Increasingly Integrated World Economy, by Michael Mussa, Paul Masson, Alexander Swoboda, Esteban Jadresic, Paolo Mauro, and Andy Berg. 2000.

192. Macroprudential Indicators of Financial System Soundness, by a staff team led by Owen Evans, Alfredo M. Leone, Mahinder Gill, and Paul Hilbers. 2000.

191. Social Issues in IMF-Supported Programs, by Sanjeev Gupta, Louis Dicks-Mireaux, Ritha Khemani, Calvin McDonald, and Marijn Verhoeven. 2000.

190. Capital Controls: Country Experiences with Their Use and Liberalization, by Akira Ariyoshi, Karl Habermeier, Bernard Laurens, İnci Ötker-Robe, Jorge Iván Canales Kriljenko, and Andrei Kirilenko. 2000.

189. Current Account and External Sustainability in the Baltics, Russia, and Other Countries of the Former Soviet Union, by Donal McGettigan. 2000.

188. Financial Sector Crisis and Restructuring: Lessons from Asia, by Carl-Johan Lindgren, Tomás J.T. Baliño, Charles Enoch, Anne-Marie Gulde, Marc Quintyn, and Leslie Teo. 1999.

187. Philippines: Toward Sustainable and Rapid Growth, Recent Developments and the Agenda Ahead, by Markus Rodlauer, Prakash Loungani, Vivek Arora, Charalambos Christofides, Enrique G. De la Piedra, Piyabha Kongsamut, Kristina Kostial, Victoria Summers, and Athanasios Vamvakidis. 2000.

186. Anticipating Balance of Payments Crises: The Role of Early Warning Systems, by Andrew Berg, Eduardo Borensztein, Gian Maria Milesi-Ferretti, and Catherine Pattillo. 1999.

185. Oman Beyond the Oil Horizon: Policies Toward Sustainable Growth, edited by Ahsan Mansur and Volker Treichel. 1999.

184. Growth Experience in Transition Countries, 1990-98, by Oleh Havrylyshyn, Thomas Wolf, Julian Berengaut, Marta Castello-Branco, Ron van Rooden, and Valerie Mercer-Blackman. 1999.

183. Economic Reforms in Kazakhstan, Kyrgyz Republic, Tajikistan, Turkmenistan, and Uzbekistan, by Emine Gürgen, Harry Snoek, Jon Craig, Jimmy McHugh, Ivailo Izvorski, and Ron van Rooden. 1999.

182. Tax Reform in the Baltics, Russia, and Other Countries of the Former Soviet Union, by a staff team led by Liam Ebrill and Oleh Havrylyshyn. 1999.

Note: For information on the titles and availability of Occasional Papers not listed, please consult the IMF's Publications Catalog or contact IMF Publication Services. 
Evolution and Performance of Exchange Rate Regimes

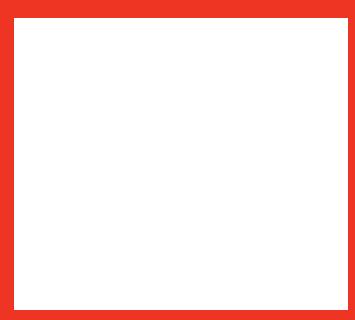

